
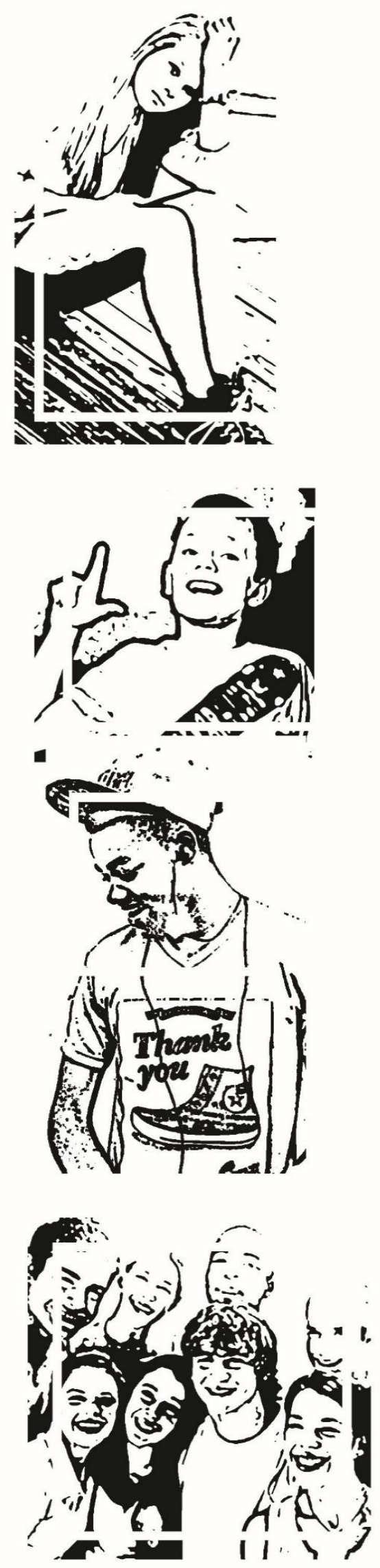

Silvia Maria Balieiro Nigro

\section{Qualidade de vida, adolescência e doença crônica}

Tese apresentada à Faculdade de Medicina da Universidade de São Paulo para obtenção de título de Doutor em Ciências

Programa de Ciências Médicas

Área de concentração: Educação e Saúde

Orientadora: Prof. ${ }^{a}$ Dr. ${ }^{a}$ Patrícia Zen Tempski

(Versão corrigida. Resolução CoPGr 6018/11, de 13 de outubro de 2011. A versão original está disponível)

\section{SÃO PAULO}


Dados Internacionais de Catalogação na Publicação (CIP)

Preparada pela Biblioteca da

Faculdade de Medicina da Universidade de São Paulo

Oreprodução autorizada pelo autor

Nigro, Silvia Maria Balieiro

Qualidade de vida, adolescência e doença crônica /

Silvia Maria Balieiro Nigro - - São Paulo, 2018.

Tese(doutorado)--Faculdade de Medicina da

Universidade de São Paulo.

Programa de Ciências Médicas. Área de

Concentração: Educação e Saúde.

Orientadora: Patrícia Zen Tempski.

Descritores: 1.Qualidade de vida 2. Adolescente

3.Doença crônica 4. Resiliência psicológica 5. Adaptação psicológica 6.Relações médico-paciente

7. Comportamento do adolescente

USP/FM/DBD-089/18 


\section{Qualidade de vida, adolescência e doença crônica}

Tese apresentada à Faculdade de Medicina da Universidade de São Paulo para obtenção de título de Doutor em Ciências

Programa de Ciências Médicas

Área de concentração: Educação e Saúde

Orientadora: Prof. ${ }^{a}$ Dr. ${ }^{a}$ Patrícia Zen Tempski 


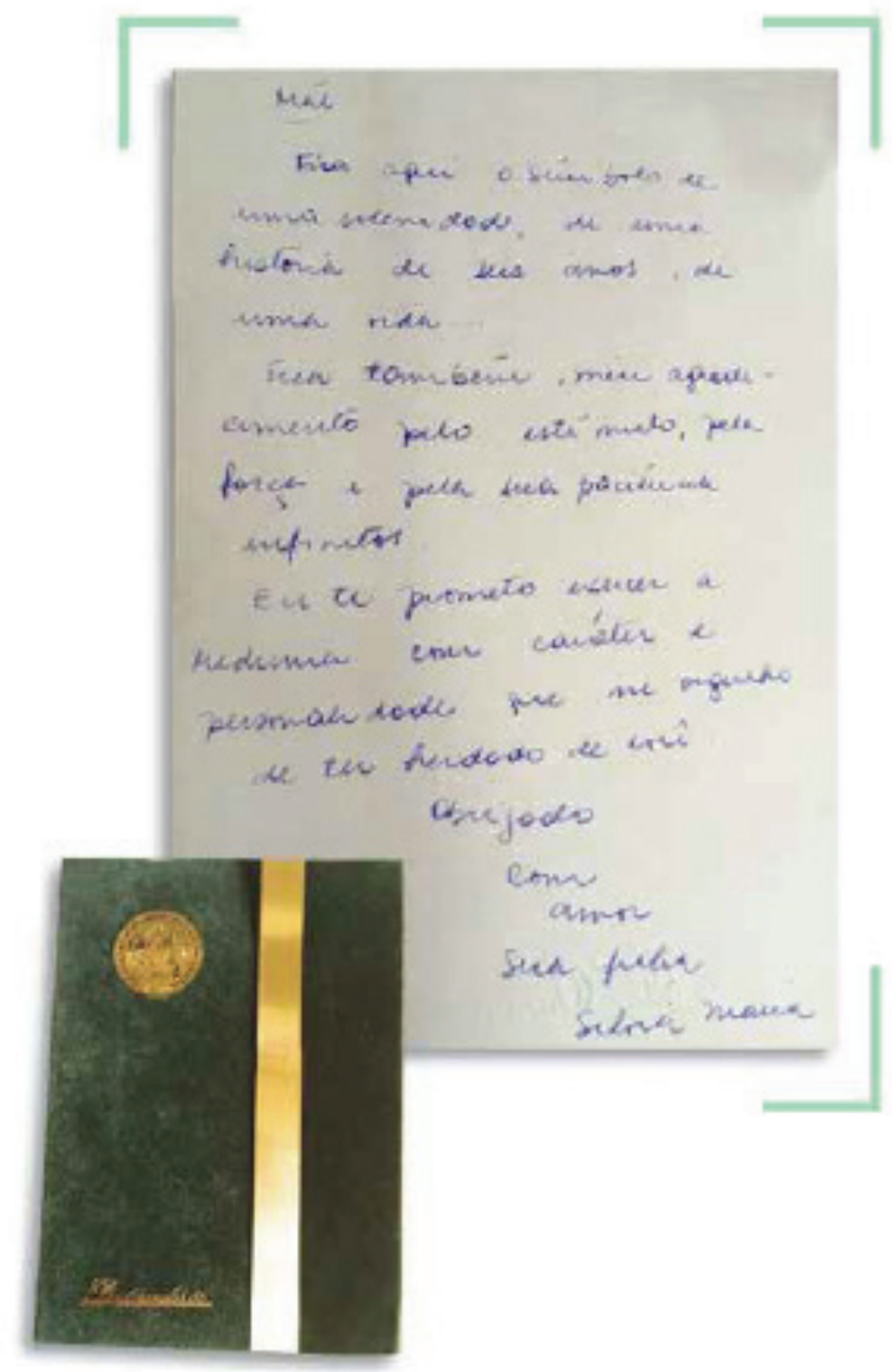

Assim dediquei meu convite de formatura ao me tornar médica, espero estar honrando minha promessa.

Dedico esta tese, mais de 30 anos depois, a mais um dos exemplos que recebi durante toda a vida, na missão das mais importantes, a de ensinar. À brilhante professora, minha mãe, Lia, in memoriam 
Aos meus filhos, Ricardo e Pedro, meus amores, estímulo para viver e melhorar a cada dia.

Ao meu marido, João, meu eterno e amado companheiro. Aos meus irmãos, Marise e Sérgio e minhas sobrinhas, Mariana, Nina e Martina, minha família, meu bem maior. 
À minha orientadora, Prof. ${ }^{a}$ Dr. $^{a}$ Patrícia Zen Tempski, que com carinho, generosidade, competência, bom humor e infinita paciência com minha ansiedade não me deixou desistir, me incentivou e me mostrou os caminhos desta trajetória tão nova e tão desafiadora para mim, a pesquisa. Sua amizade é nova, mas espero que dure para sempre.

À minha co-orientadora, Prof. ${ }^{a}$ Dr. $^{a}$ Maria José Carvalho Sant'Anna, que calorosamente me abriu as portas da Clínica de Adolescência do Departamento de Pediatria da Santa Casa de Misericórdia de São Paulo. Onde e com quem aprendi e aprendo muito até hoje sobre a Medicina de Adolescentes e sobre ensinar. Mais que tudo agradeço sua amizade, estímulo e confiança.

Ao Prof. Dr. Milton de Arruda Martins, pelo privilégio da oportunidade de ingressar na pós-graduação, voltando a minha casa, a Faculdade de Medicina da Universidade de São Paulo e das valorosas contribuições diretas e indiretas no meu trabalho de pesquisa.

À Santa Casa de Misericórdia de São Paulo. Depois de anos convivendo com tantos amigos da casa e há 6 anos trabalhando nela, finalmente entendi o valor e o peso caloroso de cada "tijolinho" desta instituição, eles são mágicos.

Às minhas amigas queridas de faculdade, eternas amigas e irmãs de coração, incentivadoras desta tese, pela ajuda e contribuições técnicas, científicas e emocionais inestimáveis em todo processo nestes anos e por me ouvirem: Prof. $^{a}$ Dr. ${ }^{a}$ Rosa Maria Affonso Moysés, Prof. ${ }^{a}$ Dr. ${ }^{a}$ Beatriz Helena Carvalho Tess, Prof. ${ }^{a}$ Dr. ${ }^{\text {a }}$ Thais Mauad.

Às minhas irmãs de vida, simplesmente por fazerem parte da minha vida e por se tornarem exemplos de relacionamentos de qualidade e suporte mútuo: Fernanda Marciano Consolim Colombo, Maria Fernanda Hussid, Marisa Ortiz Kfouri, Cristina Maria Banduk Seguim, Nidia de Castro Bastos, Priene Teani Galvão, Liliane Kopel , Silvana Chedid Grieco e Rejane Lopes de Moura. Se a longevidade depende mesmo disto ...vamos viver até os cem anos. 
Aos meus parceiros de jornada no aprendizado e exercício da Medicina de Adolescentes: Prof. ${ }^{a}$ Dr. ${ }^{a}$ Maria Ignez Saito, que me inspirou a estudar e a abraçar a causa da adolescência. Em especial pelo companheirismo, à jovem e promissora Giovanna Chekin Portella e ao amigo histórico Carlos Alberto Landi. E aos colegas da Clínica de Adolescência do Departamento de Pediatria da Santa Casa de Misericórdia de São Paulo: Benito Lourenço, Lucimar Aparecida Francoso e Talita Poli Biason e pela histórica presença da Prof. ${ }^{a}$ Dr. ${ }^{a}$ Verônica Coates.

Aos meus amigos queridos do Hospital Samaritano de São Paulo, parceiros de trabalho por 24 anos, em especial à Dr. a Ligia Reis de Queirós que foi a primeira a me incentivar a começar a estudar Medicina de Adolescentes há 10 anos.

Aos amigos e colegas do Pronto Atendimento e do Programa Cuidando de quem Cuida do Hospital Sírio Libanês que me acolheram e me incentivaram nestes últimos quase 6 anos, nas pessoas da Prof. ${ }^{a}$ Dr. $^{a}$ Maria Zilda de Aquinno, Prof. Dr. Fernando Ganem, pelo apoio e amizade históricos. E à Prof. ${ }^{a}$ Dr. ${ }^{a}$ Ivana Lie Makita Abe e todos os novos e valorosos amigos que fiz na instituição e são meus incentivadores pessoais e profissionais.

Aos meus colegas de pós-graduação, Fernanda Brenneisen Mayer, Munique Almeida Peleias, Sylvia Enns e as do grupo de pesquisa qualitativa, Cristiane Gonçalves da Mota, Rosângela Chao, Luciana de Almeida Tavares, Mariana Cérron e Estefânia Lima, pela cumplicidade e por toda ajuda nessa caminhada.

À Renata Kobayasi, em especial pela dedicação nas análises estatísticas e pelo tempo que investiu no meu trabalho.

À Fernanda Magalhães Arantes Costa pela ajuda na submissão do artigo científico desta tese e sempre me salvar de todos os percalços de última hora.

À Rosana Vilela, por sua excelência e dedicação para responder minhas dúvidas mais básicas sobre toda a burocracia relacionada ao trabalho.

Ao Erick Peleias pelo profissionalismo e criatividade na finalização e arte final desta tese. 
À minha secretária e amiga Elisabete Nunes da Silva que carrega comigo cada passo do caminho no trabalho com muita eficiência e bom humor. Há 22 anos.

Aos médicos das Especialidades Pediátricas do Departamento de Pediatria da Santa Casa de Misericórdia de São Paulo, Renata Maria de Noronha, Luiz Eduardo Procópio Calliari, Simone Paiva Laranjo Martins, Neiva Damasceno, Liane H. Catani, Maria Carolina dos Santos, Silvana Brasilia Sacchetti e aos residentes e alunos da do Departamento de Pediatria da Santa Casa de São Paulo, que me auxiliaram na coleta de dados.

Ao meu marido, João, e meus filhos, Ricardo e Pedro, pela companhia, paciência e incentivo em toda minha carreira profissional.

E, finalmente a todos adolescentes que participaram desta tese do Departamento de Pediatria da Santa Casa de São Paulo e todos os demais que de alguma foram atendidos por mim, por residentes ou alunos sob minha supervisão na minha recente e curta carreira de professora, pela oportunidade de aprender com eles e deixar um pouco de mim como pessoa e profissional em cada um deles. 


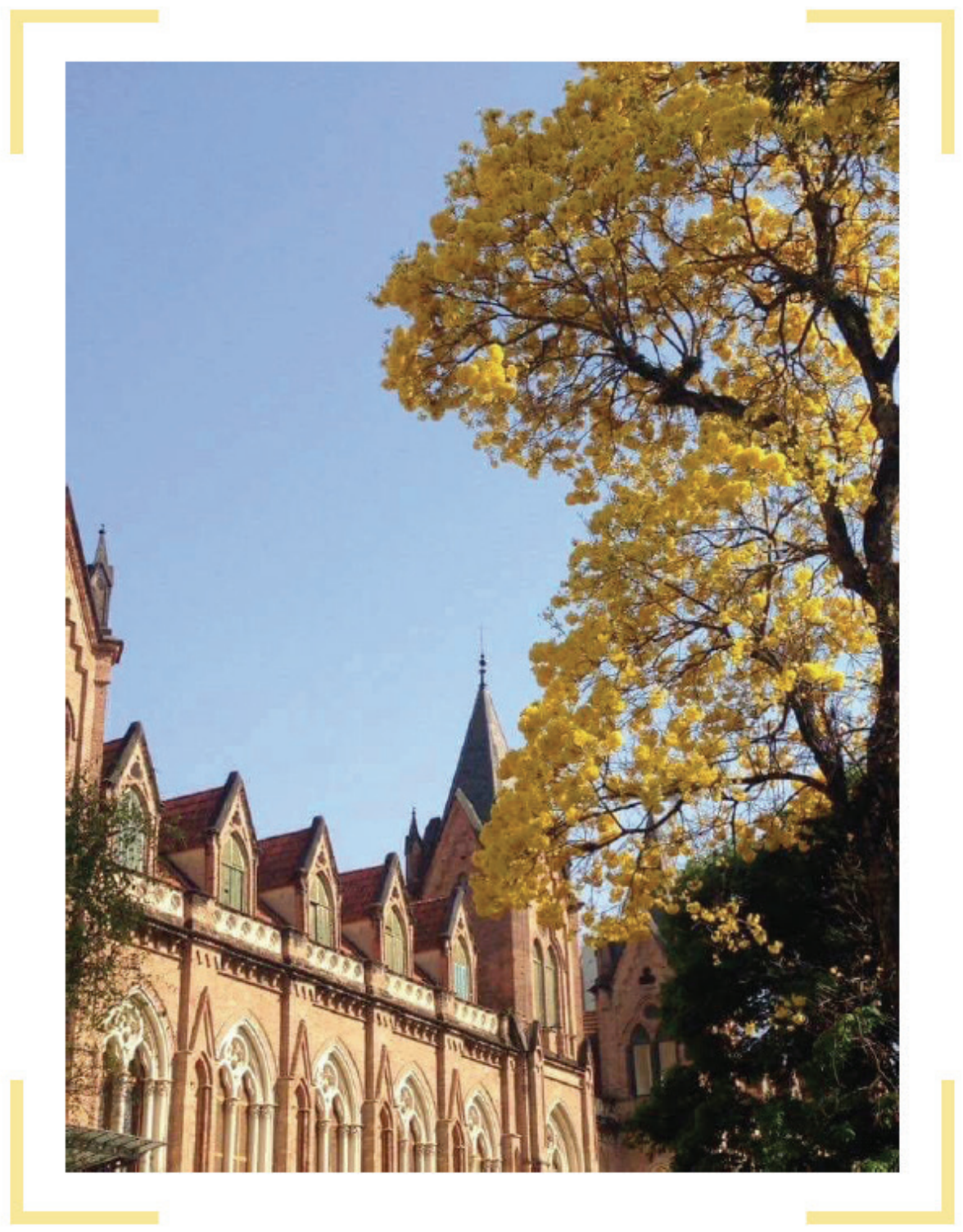

"... Eu posso lidar com isso. Eu acho que não preciso me diferenciar por causa da minha doença" (Fem.,15 anos) 


\section{NORMATIZAÇÃO ADOTADA}

Esta tese está de acordo com as seguintes normas, em vigor no momento desta publicação:

Referências: adaptado de International Committee of Medical Journals Editors (Vancouver).

Universidade de São Paulo. Faculdade de Medicina. Divisão de Biblioteca e Documentação. Guia de apresentação de dissertações, teses e monografias. Elaborado por Anneliese Carneiro da Cunha, Maria Julia de A. L. Freddi, Maria F. Crestana, Marinalva de Souza Aragão, Suely Campos Cardoso, Valéria Vilhena. 3a ed. São Paulo: Divisão de Biblioteca e Documentação; 2011.

Abreviaturas dos títulos dos periódicos de acordo com List of Journals Indexed in Index Medicus. 
SUMÁRIO

LISTA DE SIGLAS

LISTA FIGURAS, QUADROS E TABELAS

RESUMO

ABSTRACT

INTRODUÇÃO.

HIPÓTESES E OBJETIVOS

Hipótese

Objetivo geral.

Objetivos específicos

MÉTODOS

Aprovação do projeto de estudo

Caracterização do estudo

Participantes.

Questões éticas do estudo

Coleta de dados fase I

Protocolo do grupo focal

Análise de dados qualitativos............................................................... 42

Coleta de dados fase II................................................................. 43

Avaliação da qualidade de vida................................................................ 44 
Avaliação da Resiliência.

Análise de dados quantitativos

RESULTADOS

Caracterização da amostra

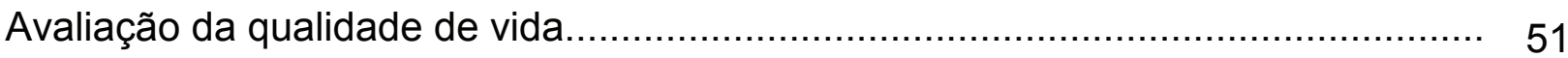

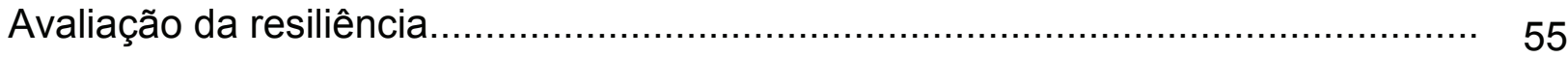

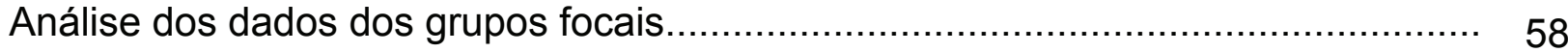

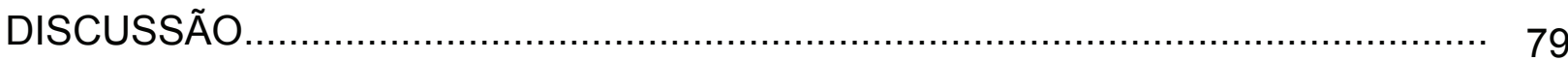

Qualidade de Vida, Doença Crônica e Adolescência........................................ 80

Percepção da Doença e Desenvolvimento Pessoal.................................... 88

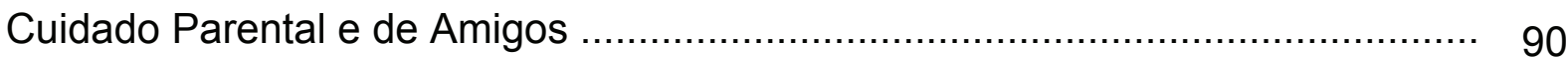

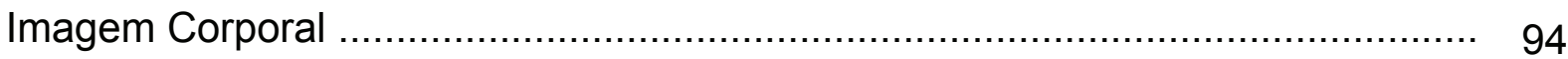

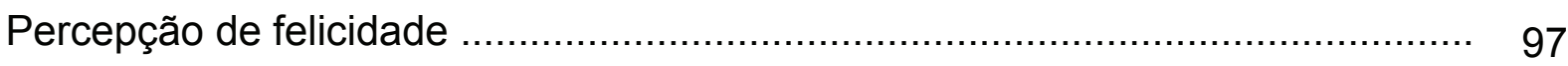

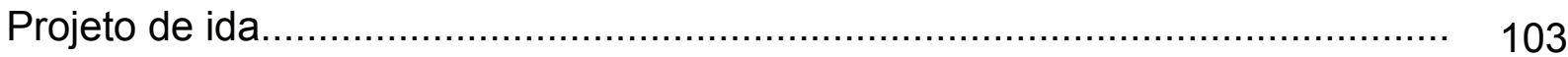

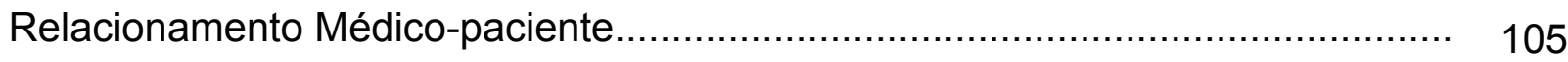

Limitações e força do estudo............................................................ 109

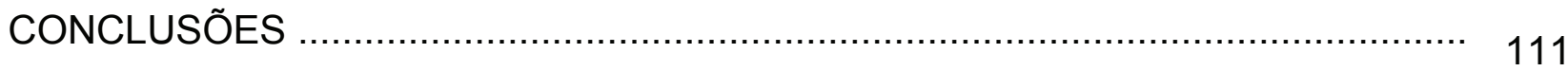

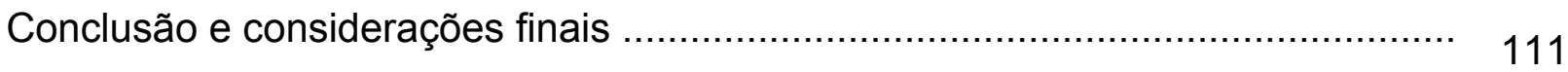

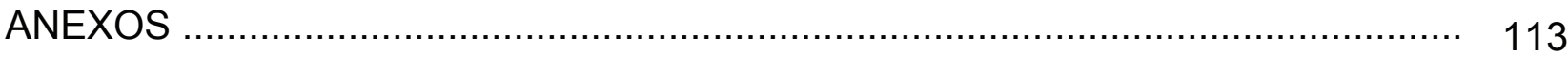

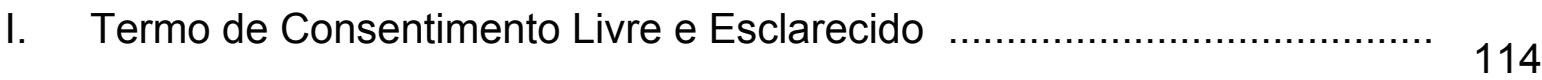

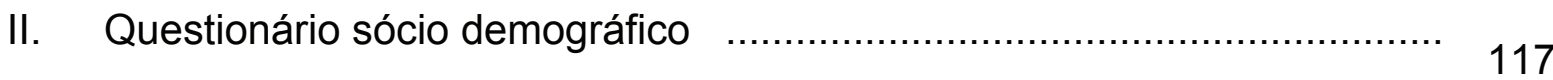




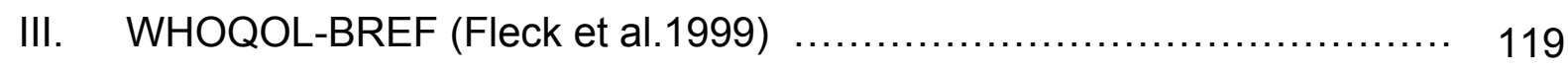

IV. RS - 14 (ResilienceScale)-Escala de Resiliência de Wagnild\& Young … 127

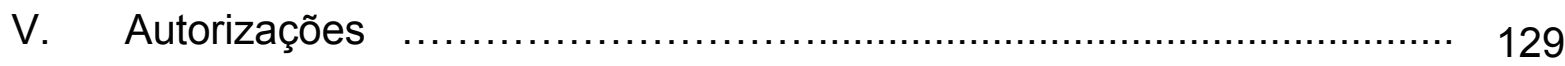

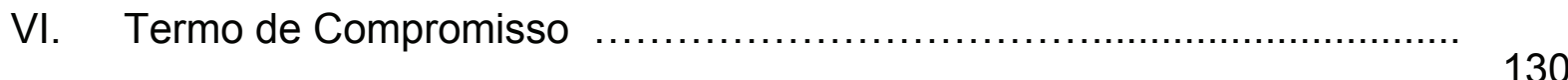

VII. Parecer Consubstanciado do Comitê de Ética e Pesquisa da Irmandade da Santa Casa de Misericórdia de São Paulo

VIII. Aprovação do Comitê de Ética e Pesquisa da Faculdade de Medicina da Universidade de São Paulo 
LISTA DE SIGLAS

[P25-P75] Intervalo entre Percentil 25 e 75

CASP Critical Appraisal Skills Programme

CEDEM Centro de Desenvolvimento de Educação Médica

CEP Código de endereçamento postal

CDC Center of Disease Control

COREQ Consolidated criterio for reporting qualitative research

CLT Consolidação das Leis do Trabalho

DCNT Doenças Crônicas Não Transmissíveis

DP Desvio Padrão

ECA Estatuto da Criança e do Adolescente

ENEM Exame Nacional do Ensino Médio

ETEC Escola Técnica

FCMSCSP Faculdade de Ciências Médicas da Santa Casa de São Paulo

FMUSP Faculdade de Medicina da Universidade de São Paulo

HIV Vírus da Imunodeficiência Humana

HBSC Health Behaviour In School-Aged Children)

IEP Inventário de Estilos Parentais (IEP),

IBGE Instituto Brasileiro de Geografia e Estatística

OMS Organização Mundial da Saúde

ONU Organização das Nações Unidas

OPAS Organização Panamericana da Saúde

QV Qualidade de Vida

QVRS Qualidade de Vida Relacionada à Saúde

RG Registro geral

SPSS Statistical Package for the Social Sciences

TDAH Transtorno De Déficit De Atenção E Hiperatividade

TCLE Termo de Consentimento e Livre e Esclarecido 
THE WHOQOL GROUP

The World Health Organization Quality of Life group

TV

Televisão

WHOQOL World Health Organization Quality of Life

WHOQOL-

BREF

The World Health Organization Quality of Life instrument 


\section{LISTA DE FIGURAS, QUADROS E TABELAS}

Figura 1 Documentação fotográfica dos grupos focais

Figura 2 Imagem do livro infanto-juvenil "Eu, Super" e da
alimentação oferecidos como brindes éticos aos participantes.

Figura 3 Fluxograma de perdas do estudo.

Quadro 1 Domínios do WHOQOL-BREF.

Quadro 2 Domínios do RS - 14.

Quadro 3 Intensidade de resiliência - escore global do RS - 14

Tabela 1

Distribuição do diagnóstico etiológico dos participantes do estudo.

Tabela 2 Distribuição do grau de escolaridade da amostra.

Tabela 3

Qualidade de vida por escore geral em autoavaliação por idade, sexo e ano escolar perdido. Mediana dos escores dos domínios do WHOQOL-BREF

Tabela 4 de acordo com sexo. Mediana dos escores dos domínios do WHOQOL-BREF

Tabela 5 por ano letivo perdido.

Tabela 6 Mediana dos escores dos domínios do WHOQOL-BREF por grupo etário.

Tabela 7 Mediana dos escores de resiliência global e por domínios.

Mediana dos escores de resiliência global, por sexo,

Tabela 8 idade e ano letivo perdido.

Tabela 9 Distribuição do grau de escolaridade dos pais ou responsáveis dos respondentes. Mediana dos escores de resiliência global, qualidade de

Tabela 10 vida, domínios por escolaridade dos pais.

Tabela 11 Análise qualitativa relativa às respostas da pergunta "Em que sua vida é diferente em relação aos outros adolescentes?"

Tabela 12

Análise qualitativa relativa às respostas da pergunta "Como sua família e amigos lidam com as questões relativas à sua saúde?"

Tabela 13 Análise qualitativa relativa às respostas da pergunta "Como você se sente em relação ao seu tratamento? 
Tabela 14

Análise qualitativa das respostas relativa à pergunta

"Como você vê seu corpo?"

Tabela 15

Análise qualitativa relativa às respostas da pergunta "O

que faz você sentir melhor? O que te alegra? "

Análise qualitativa relativa às respostas da pergunta

Tabela 16

"Quais são seus projetos para o futuro?"

72

Análise qualitativa relativa às respostas da pergunta "Que

Tabela 17 conselho você daria ao profissional de saúde que o

atende?" 
RESUMO

Nigro SMB. Qualidade de vida, adolescência e doença crônica [tese]. São Paulo: Faculdade de Medicina, Universidade de São Paulo; 2018.

INTRODUÇÃO: Novas abordagens terapêuticas possibilitaram a sobrevida de crianças com doenças graves permitindo que atinjam a adolescência. $O$ impacto da doença crônica no adolescente afeta seu desenvolvimento e qualidade de vida. OBJETIVO: Analisar a percepção de adolescentes com doença crônica acerca das interações da sua condição de saúde com as peculiaridades biopsicossociais da adolescência e seu impacto na qualidade de vida, identificando as estratégias de enfrentamento utilizadas, e avaliar os escores de resiliência e qualidade de vida.MÉTODOS: O estudo qualiquantitativo transversal e exploratório, envolveu 31 adolescentes (12-18 anos) em tratamento de doenças crônicas no ambulatório de especialidades pediátricas do Departamento de Pediatria da Faculdade de Ciências Médicas da Santa Casa de São Paulo. Coleta de dados utilizou: autoavaliação, questionário sociodemográfico, WHOQOL-BREF, RS14-Escala e grupos focais.RESULTADOS: Idade média dos participantes foi $15,1 \pm 1,5$ anos, 20 adolescentes eram do sexo feminino $(64,5 \%)$ e 11 masculino (35,5\%). A percepção da qualidade de vida por autoavaliação não variou em relação ao sexo, grupo etário, ano letivo perdido e grau de escolaridade dos pais. Menores escores de resiliência estavam associados ao atraso escolar. Os adolescentes com doença crônica percebem suas limitações e experimentam o desenvolvimento pessoal a partir do processo de adoecimento e tratamento, que gera sentimentos ambíguos como revolta pelo desconforto e dor, em contraste com a auto-percepção do desenvolvimento de resiliência. Valorizam de modo ambivalente a rede de suporte representada pela família e amigos. Destacam sentimentos de constrangimento referentes à imagem corporal e seus efeitos sobre a autoestima. Apreciam as oportunidades de lazer como esporte, mídias e atividades relacionadas à música. Reconhecem os relacionamentos sociais e têm vínculos e modelos entre amigos, família e parceiros. Atividades básicas como comer e dormir foram consideradas fatores de promoção de bem-estar. Os adolescentes com doenças crônicas têm projetos de vida, sonhos mágicos e planos reais que remetem a futuras profissões no campo da saúde e cuidado. CONCLUSÕES: A despeito da doença crônica, os adolescentes que participaram do estudo têm sonhos, desejos e comportamentos sociais esperados nesta fase do ciclo vital. A doença crônica tem impacto na sua socialização e escolarização. Aqueles com maiores escores de resiliência tiveram menos atraso escolar. Desenvolvem comportamentos sociais adaptativos e contam com apoio de pais e amigos. Desejam e têm condições de participar do seu processo terapêutico. 
Descritores: qualidade de vida; adolescente; doença crônica; resiliência psicológica; adaptação psicológica; relações médico-paciente; comportamento do adolescente 


\section{ABSTRACT}

Nigro SMB. Quality of life, adolescence and chronical diseases [thesis]. São Paulo: "Faculdade de Medicina, Universidade de São Paulo"; 2018.

INTRODUCTION: New therapeutic approaches have made possible for children with serious diseases to live up until adolescence. The impact of a chronical disease in an adolescent affects its development and quality of life.

OBJECTIVE: to analyze the perception of adolescents with chronical diseases of the interactions of their life conditions with the biopsychosocial peculiarities of the adolescence and its impact in their quality of life, indicating strategies utilized and evaluating resilience and quality of life scores.METHODS: the qualiquantitative, transversal and exploratory study involved 31 adolescents (12-18 years old), who have been having treatment of their chronical diseases in the pediatric specialties ambulatory of the Pediatrics Department of the Medical Sciences School of Santa Casa of São Paulo. The data collect involved: auto evaluation, sociodemographic questionnaires, WHOQOL-BREF, RS-14-scale and focus groups.RESULTS: the participants were 15 years old in average $( \pm 1,5)$, there were 20 adolescents female gender $(64,5 \%)$ and other $11(35,3 \%)$ male. Their perception of quality of life in their auto evaluation did not vary according to their gender, age, lost school year or degree of education of their parents. The lowest resilience scores were associated with school delay. The adolescents notice their limitations and try the social development through the process of sickening and treatment, generating ambiguous feelings like revolt and pain, contrasting with their auto-perception of the development of resilience. They value ambivalently the support network composed of family and friends. They highlight feelings of embarrassment due to their corporal image and their impacts on the self-stem. They appreciate leisure opportunities like sports, medias and music. They acknowledge their social relationships and their models among friends, family and partners. Basic activities like eating and sleeping were considered promoting factors of well-being. The adolescents with chronical disease have life projects, magical dreams and real plans that remit to future careers in health and care fields.CONCLUSIONS: In spite of their chronical diseases, the adolescents studied have dreams, desires and social behaviors expected of them in their age range. However, their condition impacts on their socialization and education. Those with lower resilience scores had less school delay. The adolescents develop social adaptive behaviors e count on their friends and family support. They wish and have conditions to participate of their therapeutic process. 
Descriptors: quality of life; adolescent; chronic disease; resilience, psychological; adaptation, psychological; physician-patient relations; adolescent behavior 


\section{Introdução}

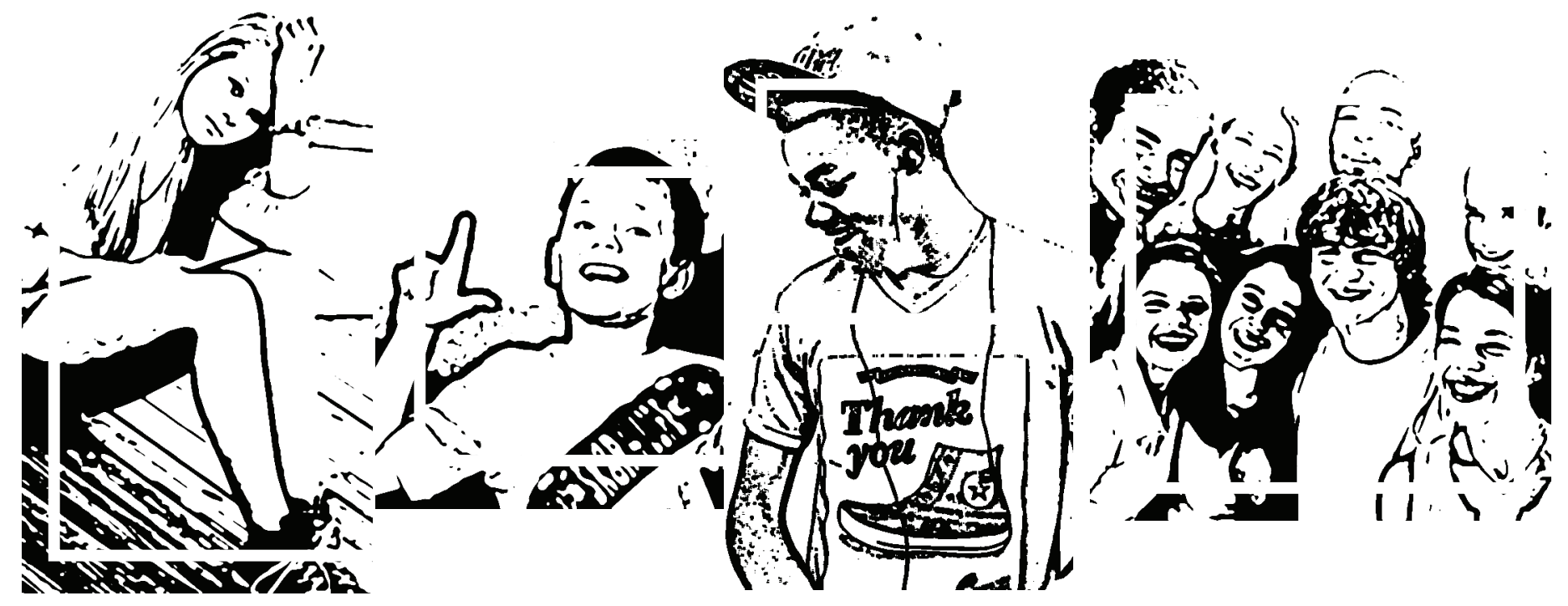


Segundo o Relatório Mundial sobre Doenças Não Transmissíveis de 2014 da Organização Mundial da Saúde (OMS), Doenças Crônicas Não Transmissíveis (DCNT) são a causa principal de mortalidade e de incapacidade prematura em todas as regiões do mundo. As principais causas de morte por DCNT foram: doenças cardiovasculares $(46,2 \%)$, cânceres $(21,7 \%)$, doenças respiratórias, incluindo asma e doença pulmonar obstrutiva crônica $(10,7 \%)$ e diabetes $(4 \%) .^{(1)}$

Anteriormente, no início do século passado, as doenças infecciosas eram as que mais levavam ao óbito. Hoje, no entanto, com as melhorias de condições sócio-econômico-culturais, a mortalidade é preponderantemente consequência das doenças crônicas não transmissíveis,

Este fenômeno, denominado "transição epidemiológica", ocorre devido à mudança do padrão de mortalidade que afeta uma população(2). No Brasil, dados do Ministério da Saúde/SVS - Sistema de Vigilância em Saúde apontam também essa tendência mundial; as DCNT são a causa de aproximadamente $72 \%$ das Mortes. ${ }^{(3)}$

Na infância e adolescência há grande variabilidade nas taxas de prevalência de condições crônicas de saúde, explicada pela diversidade considerável nos conceitos utilizados para esta faixa etária. Alguns autores dedicaram-se a revisar este conceito. Uma revisão publicada em 2007 por Van der Lee e colaboradores, concluiu que seria necessário um consenso internacional sobre a definição conceitual de condições crônicas de saúde na Infância(4,5). Outra revisão da literatura publicada em 2014, por Moreira, Gomes e Calheiros evidencia uma categorização através de análise de conteúdo temático, mostrando estreita relação entre as limitações impostas pela condição crônica e qualidade de vida em crianças e adolescentes ${ }^{(6)}$.

No presente estudo, optou se pela definição citada por Stein e Silver na qual doença crônica na infância seria definida por: "Condições que devem ter base biológica, psicológica ou cognitiva; duração de um ano ou mais e capazes de produzir uma das seguintes consequências 
(1) limitações de função, atividades ou papel social, em comparação com seus pares de idade saudáveis nas áreas: física, cognitiva, emocional, e crescimento e desenvolvimento social;

(2) dependência de uma das seguintes opções para compensar ou minimizar as limitações de função, atividades ou papel social: medicamentos, dieta especial, assistência médica, dispositivo de apoio, ou assistência pessoal;

(3) necessidade de cuidados médicos, psicológico ou serviços educacionais acima do habitual para a idade ou tratamentos especiais em curso, intervenções, ou acomodações na casa ou na escola" ${ }^{(7,8,9)}$.

Ao longo dos últimos anos, as doenças crônicas anteriormente caracterizadas como fatais passaram a ser precocemente diagnosticadas graças à evolução de novos métodos diagnósticos. Da mesma forma, o desenvolvimento de novas abordagens terapêuticas possibilitou o aumento da sobrevida de crianças nestas condições clínicas. Consequentemente, estas crianças passaram a apresentar aumento de sua sobrevida, passando pela adolescência e, em muitos casos, atingindo a idade adulta. Assim, a população de adolescentes acometidos de doenças crônicas vêm crescendo significativamente. Uma revisão sistemática de programas de desenvolvimento positivo para adolescentes com doença crônica, publicada em 2013, faz análise dos programas para jovens, incluindo os adolescentes com doenças crônicas, que implantem princípios de desenvolvimento positivo apoiando sua transição para a idade adulta a partir da realidade epidemiológica que se apresenta. Todos os anos, nos Estados Unidos, 500.000 adolescentes com necessidades específicas de cuidados de saúde chegam aos 18 anos de idade e $85 \%$ dos jovens com doenças crônicas se tornam adultos ${ }^{(10)}$.

Os adolescentes crônicos não podem ser vistos como um grupo homogêneo, pois há grande variação entre os jovens, quanto ao grau de acometimento, às perspectivas individuais de futuro e às limitações impostas pelas suas diferentes doenças de base. Observam-se desde jovens que têm sua rotina pouco alterada, até aqueles com doenças mais complexas, que 
necessitam de constante atenção diferenciada e até têm noções precoces de finitude.

Outra dificuldade que se encontra na avaliação do impacto da doença crônica em adolescentes é definir o que significa qualidade de vida para eles. A expressão "qualidade de vida" é um termo utilizado em várias áreas do conhecimento. Trata-se de um termo complexo e devido à subjetividade que representa para cada pessoa ou grupo social, pode representar felicidade, harmonia, saúde, prosperidade, morar bem, ganhar salário digno, ter amor e família, poder conciliar lazer e trabalho, ter liberdade de expressão e ter segurança(11)

Tão importante quanto estudar o controle de sintomas, a diminuição da mortalidade e o aumento da expectativa de vida, é avaliar a qualidade de vida nas pesquisas médicas. Este novo parâmetro de avaliação foi, então, incluído em estudos, uma vez que, na busca de acrescentar "anos à vida" era deixada de lado a necessidade de acrescentar "vida aos anos"(12,13).

A Organização Mundial da Saúde (THE WHOQOL GROUP, 1994) definiu qualidade de vida como a "percepção do indivíduo sobre a sua posição na vida, no contexto da cultura e dos sistemas de valores nos quais ele vive, e em relação a seus objetivos, expectativas, padrões e preocupações."(14) Tratase de conceito amplo afetado de forma complexa pela saúde da pessoa física, estado psicológico, nível de independência, relações sociais e ambiente.

Qualidade de Vida Relacionada à Saúde (QVRS) é um subconjunto do termo amplo Qualidade de Vida (QV) e recebe esta classificação por incluir os domínios físico, psicológico e social que possuem relação com a saúde. ${ }^{(14)}$ A qualidade de vida relacionada à saúde (QVRS), inicialmente mais investigada na população adulta, tem sido objeto de atenção e pesquisa na infância e adolescência devido ao impacto que o seu prejuízo pode causar em longo prazo, além do benefício que as intervenções precoces com foco na sua melhoria podem proporcionar, especialmente nas doenças crônicas. A avaliação da QVRS em crianças e adolescentes têm sido utilizada para identificar grupos e subgrupos que estejam em risco, rastrear hábitos de saúde 
e compreender melhor o impacto dos sobre a qualidade de vida dessa população. ${ }^{(15)}$

Bullinger (1993) considera que o termo qualidade de vida é mais geral e inclui uma variedade potencial maior de condições que podem afetar a percepção do indivíduo, seus sentimentos e comportamentos relacionados com o seu funcionamento diário, incluindo, mas não se limitando, à sua condição de saúde e às intervenções médicas. ${ }^{(16)}$

Para avaliar a qualidade de vida a Organização Mundial da Saúde desenvolveu instrumentos como o WHOQOL100 em 15 centros de todo o mundo, isto é, através de uma perspectiva multicultural. Os aspectos importantes da qualidade de vida foram elaborados com base em declarações feitas por pacientes com uma variedade de doenças e diversos profissionais de saúde. E ainda, o WHOQOL-BREF, versão abreviada com quatro domínios: Domínio Saúde Física, Domínio Psicológico, Domínio Relações Sociais, Domínio Ambiente. Os instrumentos foram rigorosamente testados para verificar sua validade e confiabilidade em cada um dos centros. ${ }^{(12)}$

Atualmente a qualidade de vida e sensação de bem estar tem sido associada com o conceito de resiliência. ${ }^{(17)}$ Este termo é utilizado na física definido como a capacidade de um material absorver energia quando submetido à pressão sem sofrer deformação permanente, ou seja, é capaz de recuperar sua forma original após o término da tensão. $O$ conceito de resiliência foi ampliado pela psicologia para designar a capacidade de uma pessoa de enfrentar problemas e resistir à pressão em situações adversas sem sofrer danos físicos, psicológicos ou sociais. Envolve habilidades de adaptação, flexibilidade, interação, superação e ressignificação das experiências vividas. E que, portanto, vem sendo entendido, de uma maneira geral, como o potencial de superação dos indivíduos e comunidades frente a situações adversas. ${ }^{(18)}$

Resiliência é uma característica que nos permite existir neste mundo imperfeito, visualizando o presente e o futuro com otimismo e confiança, mesmo em meio à adversidade. O resiliente não procura problemas, mas 
enxerga a possibilidade de se tornar mais forte com eles. Não se coloca em posição de vítima e procura soluções. Não é invulnerável, nem perfeito, nem isento de risco.

Mais recentemente a resiliência tem sido estudada não somente como o conjunto de características individuais, tais como a confiança, a capacidade de planejamento, o autocontrole, e a persistência que explica porque algumas pessoas reagem de forma positiva ou negativa às experiências estressantes. $A$ resiliência considerada como um processo, onde um indivíduo, para ser considerado resiliente, deve ter essas características pessoais testados na situação de risco. Demonstrando a capacidade de resposta. E como um sistema, a resiliência é definida como o resultado da interação entre o indivíduo, sua rede social e a adversidade, incluindo valores pessoais, influência cultural, social e ética. ${ }^{(19)}$ Mas a resiliência pode ser construída, incentivada e pode ser um fator crucial de prosperidade global do indivíduo, em especial numa fase tão particular de mudanças como a adolescência. ${ }^{(20)}$

A definição de adolescência é outro desafio. Para a sociologia, depende da inserção cultural, sendo singular em sociedades diversas como a oriental, indígena ou de áreas rurais, por exemplo; para a antropologia pode ser vista como um rito de passagem para o período da fase adulta. Já o direito, enxerga o adolescente conforme a legislação vigente. ${ }^{(21)}$ Atualmente a adolescência pode ser definida como um período de transição entre a infância e idade adulta. Embora impreciso, desde meados do século 20, a Organização Mundial da Saúde (OMS) considera adolescência o período de vida dos 10 aos 20 anos incompletos. $^{(22-24)}$

Recentemente, foi publicado um ponto de vista de Sawyer e colaboradores acerca dos limites de idade da adolescência. Enquanto seu início é marcado pela ativação do eixo neuroendócrino hipotalâmico-hipofisáriogonadal que deflagra a puberdade, permanece em discussão a definição do encerramento desta fase de vida. Esta discussão é influenciada por fatores biológicos, culturais e sociais. Se por um lado os padrões de crescimento mudaram com a aceleração da puberdade, que ocorre mais cedo, e reflete a melhora da saúde e da nutrição na infância, por outro a transição de papéis 
tem sido mais longa e reflete as mudanças sociais, atraso na conclusão da educação, idade em que ocorre o casamento e a paternidade. Assim, ampliar esta definição para a faixa de idade para 10 a 24 anos seria mais apropriado para estes autores. ${ }^{(25)}$

De acordo com o Estatuto da Criança e do Adolescente - ECA(26)(27) (Lei n 8069 de 13/07/90) é considerado adolescente o indivíduo entre 12 e 18 anos de idade. Segundo estimativas da Organização das Nações Unidas (ONU), os adolescentes representam cerca de $25 \%$ da população mundial. (23) Na América Latina e no Países do Caribe, os adolescentes com idades entre 10-19 que representam $16,9 \%$ da população. ${ }^{(28)}$ Dados do Instituto Brasileiro de Geografia e Estatística (IBGE 2010), mostram que cerca de $18 \%$ da população brasileira se concentra nesta faixa etária. ${ }^{(29)}$

Independente destas diferenças nos limites de idade, seguramente a adolescência é um período especial no desenvolvimento humano. $O$ adolescente, bem como suas famílias, traz, neste momento, um espectro de situações muito mais complexo, envolvendo seus cuidados de saúde numa transição para a autonomia.

A doença crônica pode ser um potente fator de estresse para 0 adolescente e sua família, bem como a convivência com a doença, seus sintomas, exposição aos procedimentos diagnósticos e terapêuticos. Eventuais restrições impostas ao que ser refere às atividades físicas, posologia e vias de administração de medicamentos, dietas especiais podem gerar sobrecarga para a rotina basal, de atividades físicas e de lazer, podendo acarretar prejuízo na socialização e absenteísmo escolar, em alguns casos, afetando as perspectivas educacionais e profissionais. ${ }^{(30)}$

Aberastury e Knobel descreveram a Síndrome da Adolescência Normal, que inclui características desta etapa da vida como sexualidade, busca de identidade, sentimento de invulnerabilidade, vivência temporal singular, afastamento progressivo de pais e a tendência grupal.(31)Mais recentemente, a literatura vem discutindo a adolescência, levando-se em conta também o desenvolvimento cerebral na adolescência conforme esta evolui no tempo. 
Nos pré-adolescentes ainda há pouco desenvolvimento das funções executivas do lobo pré-frontal. Inicia-se a mudança gradual do pensamento egocêntrico para o sociocêntrico. Há um aumento no desejo de novas informações, mas a linguagem ainda é concreta. Na adolescência inicial, o pensamento abstrato se amplia e o pensamento concreto ser reduz. Vão adquirindo funções de conservação. Ainda há pouco desenvolvimento do lobo pré-frontal e funções executivas, em especial entre os meninos.

A capacidade de resolver problemas, planejar com antecedência e de controlar a impulsividade, aparece na adolescência média, em especial entre as meninas. Esta habilidade parece se desenvolver com a conclusão do desenvolvimento lobo pré-frontal que, nos meninos, ocorre durante a adolescência tardia. Estágios mais elevados de desenvolvimento cognitivo e moral são alcançados na maioria adolescentes de ambos os sexos após os 18 anos, quando possuem potencial biológico adequado e apoio social e emocional. ${ }^{(32)}$

A vivência da adolescência nos jovens com doença crônica apresenta uma série de condições que interferem, ou mesmo se contrapõem, com a percepção da adolescência normal. No entanto, eles atravessarão a adolescência como seus pares saudáveis. Convivendo com as dores, deformidades, limitações, dependência de medicamentos e de terceiros. Socialmente não são menos idealistas ou sem desejo de liberdade, de viver e conquistar o mundo, convivendo com a superproteção de todos e a inclusão da condição crônica em projetos de futuro.

Assim, entre outros desafios que os adolescentes com doença crônica enfrentam com a transição para vida adulta estão àqueles relacionados à qualidade de vida, educação, sexualidade, perspectivas de futuro financeiro e profissional que são em muito influenciados pela sua condição de saúde. Cada indivíduo percebe estes desafios conforme seu patrimônio social, cultural e afetivo. Portanto, estudar o impacto de uma doença crônica em adolescentes a partir de sua percepção de qualidade de vida requer a participação ativa dos próprios adolescentes em todo processo. Além disso, informações sobre a 
qualidade de vida deste grupo de indivíduos podem ser usadas para monitorar o seu processo de tratamento, comparar diferentes estágios da doença.

Justifica-se este estudo pela possibilidade que ele oferece para melhor compreender o processo de adoecimento em adolescentes com doença crônica, sua percepção de qualidade de vida, os fatores de estresse e proteção, bem como seu enfrentamento e desenvolvimento pessoal. Estes dados podem contribuir para a melhoria do cuidado prestado aos adolescentes com doença crônica, à medida que profissionais da saúde conseguirem enxergá-los como sujeitos de sua vida em todos os aspectos.

O presente estudo que se propõe a entender o adolescente como protagonista de sua vida, buscando identificar aspectos que melhorem sua qualidade de vida e sucesso do processo terapêutico como um todo e utilizou os mesmos pressupostos para a escolha do seu método de pesquisa. $E$ a dar voz ao adolescente com doença crônica, compreendendo-o em toda sua complexidade de transformações dentro da instituição de assistência e na sociedade onde estão inseridos. 


\section{Hipóteses e Objetivos}

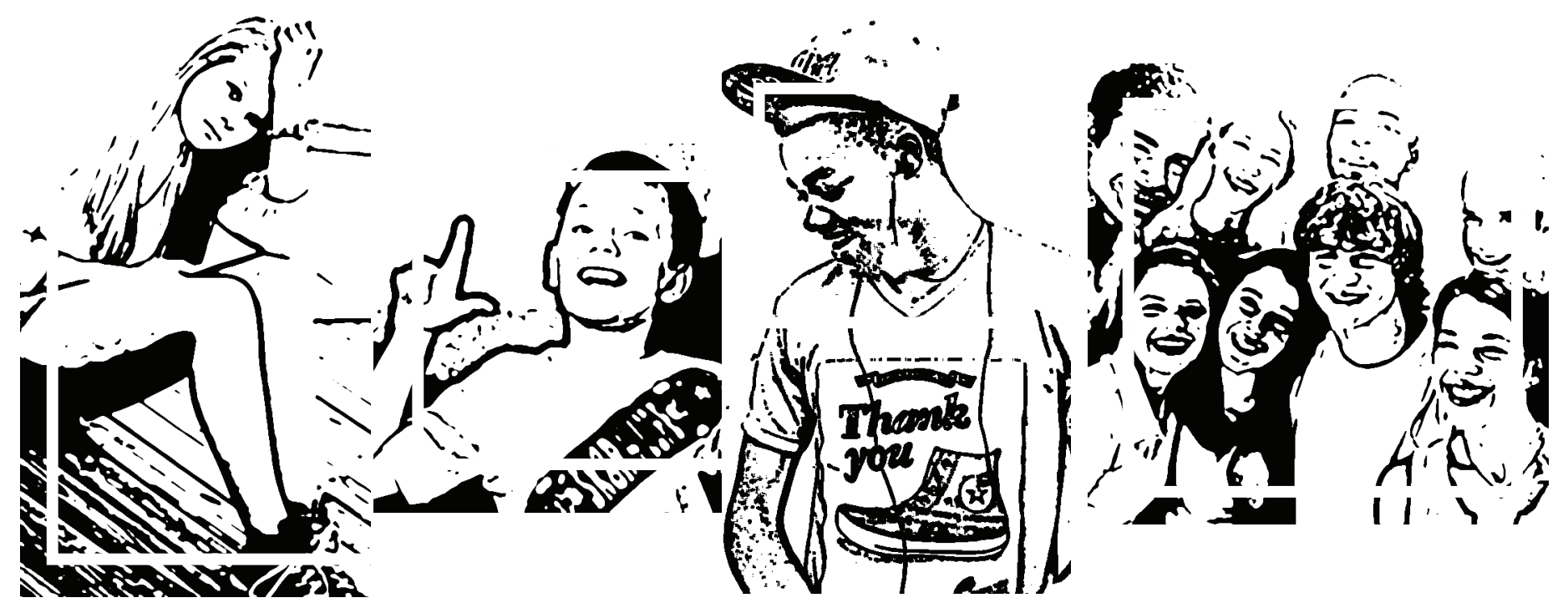




\section{HIPÓTESES}

Como hipóteses iniciais deste estudo apresentaram-se as seguintes afirmações a serem testadas:

O adolescente com doença crônica tem percepção negativa acerca da sua qualidade de vida, e, no entanto, as suas condições permitem o desenvolvimento da sua resiliência.

O adolescente com doença crônica deseja e tem condições de participar do seu processo terapêutico.

A doença crônica na adolescência não interfere nos sonhos, desejos e comportamentos sociais esperados de uma pessoa saudável nesta fase.

A doença crônica tem impacto na socialização e escolarização do adolescente.

\section{OBJETIVOS}

\section{Objetivo Geral:}

Analisar a percepção dos adolescentes com doença crônica acerca das interações da sua condição de saúde com as peculiaridades biopsicossociais da adolescência e seu impacto na qualidade de vida, identificando as estratégias de enfrentamento por eles utilizadas.

\section{Objetivos Específicos:}

Analisar a percepção dos adolescentes acerca da sua condição de saúde e qualidade de vida;

Avaliar o impacto da doença crônica no desempenho escolar;

Identificar as estratégias de enfrentamento utilizadas pelos adolescentes com doença crônica e suas as principais redes de suporte;

Avaliar os escores de resiliência e qualidade de vida entre os adolescentes com doença crônica participantes e compará-los por idade e sexo. 


\section{Métodos}

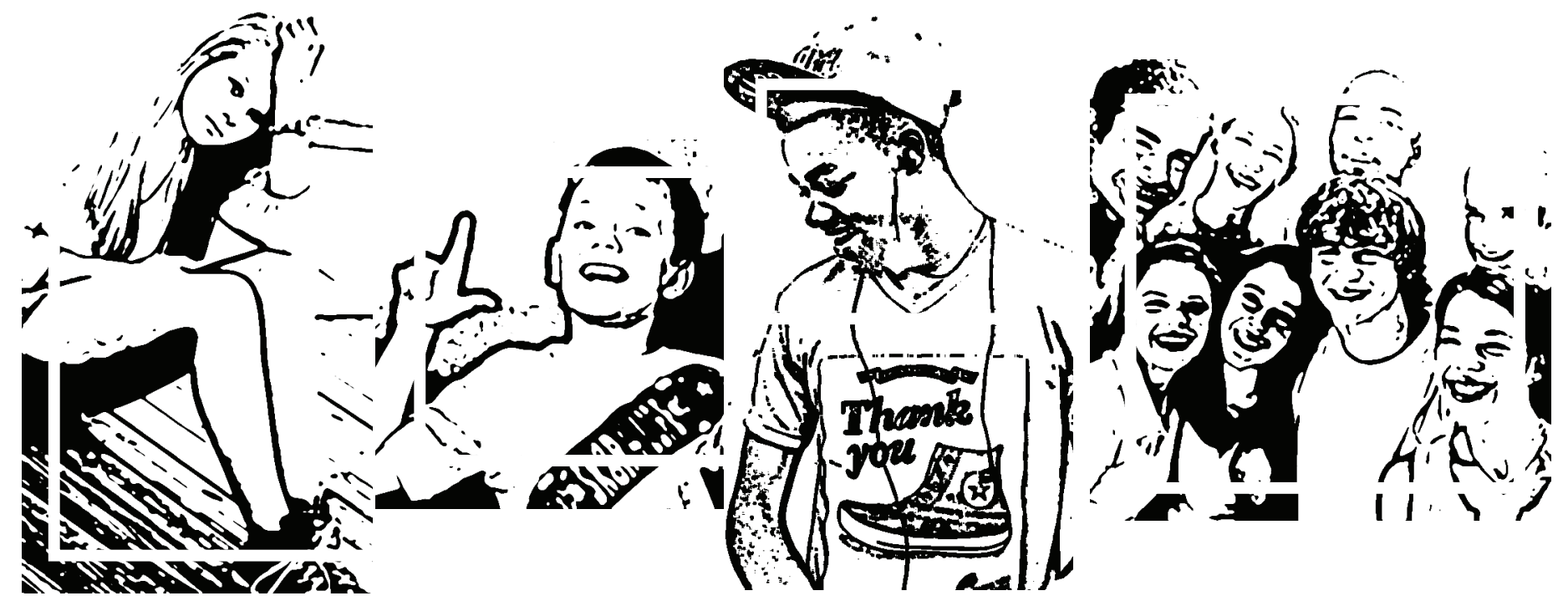




\section{MÉTODOS}

\section{Aprovação do projeto de estudo}

O Comitê de Ética em Pesquisa da Faculdade de Medicina da Universidade de São Paulo, em sessão de 10/12/2014, aprovou o Protocolo de Pesquisa $n^{\circ}$ 397/14 intitulado: "Qualidade de vida, adolescência e doença crônica" apresentado pelo Departamento de Clínica Médica.

\section{Caracterização do estudo}

Este estudo caracteriza-se por ser transversal e exploratório, que utilizou métodos de pesquisa qualitativa e quantitativa, para analisar a percepção de saúde e qualidade de vida em uma amostra de conveniência de adolescentes com doença crônica.

\section{Participantes}

Os participantes da pesquisa foram pacientes do ambulatório de especialidades pediátricas do Departamento de Pediatria da Faculdade de Ciências Médicas da Santa Casa de São Paulo (FCMSCSP). Os critérios de inclusão foram: adolescentes com idades entre 12-18 anos, conforme critério do Estatuto da Criança e do Adolescente (ECA)(27) acompanhados no ambulatório do Departamento de Pediatria da Faculdade de Ciências Médicas da Santa Casa de São Paulo nas especialidades pediátricas de endocrinologia, reumatologia, nefrologia, cardiologia, gastrenterologia, hematologia e pneumologia. Foram excluídos adolescentes em cuidados paliativos, com doença dermatológica, doença oncológica, com deficiência intelectual e os soropositivos para HIV. A fim conseguir uma amostra relativamente homogênea em relação a proposta do estudo os critérios de exclusão se justificam pois:

As manifestações dermatológicas severas interferem na imagem corporal dos adolescentes, variável importante satisfação pessoal destes. As 
doenças oncológicas e os em cuidados paliativos trazem a percepção de finitude muito antes do que se espera para faixa etária. Os soropositivos para HIV têm as questões relacionadas ao exercício da sexualidade e projetos de constituição de família diversos dos seu pares. E o método de pesquisa não é adequado aos adolescentes com deficiência intelectual.

\section{Questões éticas do estudo}

Foi garantido o anonimato dos participantes e acesso aos resultados da pesquisa. A participação foi voluntária, não estando previsto nenhum tipo de remuneração ou recompensa de qualquer natureza, bem como a recusa em participar não incorreu em perda ou dano de qualquer natureza. Ela foi condicionada à assinatura do paciente participante e seu responsável legal do Termo de Consentimento Livre e Esclarecido - TCLE (Anexo I).

Fez parte da ética desta pesquisa oferecer acesso a apoio psicológico aos participantes, caso fosse necessário, considerando ser esta pesquisa de risco baixo, mas não inexistente por se tratar de questões ligadas a aspectos psicoemocionais. O apoio psicológico seria realizado no próprio serviço de Psicologia da Santa Casa de São Paulo. No entanto ela não foi necessária por falta de demanda dos participantes.

\section{$\underline{\text { Coleta de dados fase I }}$}

O estudo foi realizado no Ambulatório do Departamento Pediatria da Faculdade de Ciências Médicas da Santa Casa de São Paulo em duas fases, uma qualitativa e a outra quantitativa.

O recrutamento dos participantes da pesquisa foi feito inicialmente por telefone pela pesquisadora. Para que não tivessem prejuízo de seus compromissos escolares, nem absenteísmo de seus responsáveis ao trabalho, a escolha das datas dos grupos, em sua maioria, coincidiu com as datas das consultas.

Os encontros foram realizados em horários contíguos das consultas agendadas com as respectivas especialidades pediátricas. 
Foram realizados cinco grupos focais com adolescentes com idade entre 12 e 18 anos, mantendo a diversidade quanto ao sexo e diagnóstico de saúde. A composição dos grupos focais respeitou o critério de limite de idade, sendo um grupo composto por adolescentes entre 12 a 14 anos e quatro por adolescentes entre 15 a 18 anos.

O desenvolvimento psicoemocional dos adolescentes difere entre os sexos e se modifica ao longo dos anos da adolescência. Encontram-se diferentes classificações na literatura. A revisão de 2015, publicada por Verônica Gaete, classifica a em: ${ }^{(33)}$

Adolescência inicial: de 10 a 13-14 anos.

Adolescência média: 14-15 a 16-17 anos.

Adolescência tardia: a partir de 17-18 anos em diante

Enquanto que em 2005 a Organização Panamericana da Saúde(OPAS), no documento cientifico : Youth: choices and change: promoting healthy behaviors in adolescents, classifica de maneira mais ampla: ${ }^{(32)}$

Pré-adolescente refere-se a meninas com idade entre 9-12 anos e meninos com idade entre 10-13 anos;

Adolescente inicial refere-se às meninas com idade entre 12-14 anos e meninos com idade entre 13-15 anos;

Adolescente médio refere-se a meninas com idade entre 14-16 anos e meninos com idade entre 15-17 anos;

Adolescente tardia refere-se a meninas com idades entre 16-18 anos e meninos com idades entre 17-18 anos;

A juventude refere-se a idades entre 18-21 anos em ambos os sexos; e adulto jovem refere-se às idades entre 21-24 anos, para ambos os sexos.

Para análise dos resultados deste estudo, optou-se por separar os participantes por idade em dois grupos. Os menores de 15 anos e acima de 15 anos completos. 
Geralmente nesta idade, percebe-se o comportamento diferenciado entre adolescentes característicos da adolescência média e tardia, onde a variabilidade do desenvolvimento e as diferenças de gênero se mostram menos marcantes.

A técnica de grupo focal se caracteriza essencialmente pela interação entre participantes e pesquisador. Os dados são produzidos a partir da discussão com temas específicos. ${ }^{(34)}$ No grupo focal se estimula a interação e o debate entre os participantes, permitindo que os temas abordados sejam mais aprofundados. Os participantes, de modo geral, ouvem as opiniões dos outros antes de formar as suas próprias e, constantemente, mudam de posição, ou fundamentam melhor sua opinião inicial, quando envolvidos na discussão. ${ }^{(35)}$ Este método contrasta com a técnica de aplicação de questionários fechados ou entrevistas individuais, onde o indivíduo se encontra isolado e emite suas opiniões sem esta oportunidade.

Segundo Soares e colaboradores (2011) a inclusão de adolescentes como sujeitos de pesquisa e na produção de conhecimento depende, portanto, dos mesmos serem desde sempre incluídos, respeitados seus limites e capacidades, no processo complexo de diagnóstico/tratamento e produção de saúde. Além disso, no processo da pesquisa, é necessária a habilidade e criatividade dos pesquisadores em adaptar instrumentos que se tornem interessantes e mobilizem os adolescentes a socializarem suas experiências. Esta revisão provoca ainda uma reflexão acerca da posição dos adolescentes e suas necessidades, expectativas e vivências específicas. O estudo da qualidade de vida nos adolescentes com doenças ou submetidos a tratamentos médicos, requer a aplicação de uma metodologia que esteja atenta às particularidades deste período da vida e suas transformações. ${ }^{(36)}$

\section{Protocolo do grupo focal}

O convite foi realizado por contato telefônico, realizado pela pesquisadora, com os adolescentes e seus os responsáveis. Neste contato, após a apresentação da pesquisadora, foi descrita sumariamente a proposta do 
estudo. Ocorrendo a aceitação, foi checado o endereço com CEP, e-mail e celular para novos eventuais contatos. Em caso de não aceitação do convite, foi anotado o motivo de recusa e este foi substituído por outro sujeito de pesquisa de perfil semelhante para garantir a diversidade do grupo focal.

Aos participantes, foi solicitado que comparecessem com o responsável, para assinatura do TCLE-Termo de Consentimento Livre e Esclarecido, uma vez que os participantes são adolescentes menores de idade. Os pais ou responsáveis foram acomodados na sala de espera do ambulatório.

No que se refere ao ambiente da pesquisa, o local foi preparado para receber os participantes, em sala privativa, adequadamente iluminada sob temperatura neutra, livre de interrupções, respondendo as demandas de conforto e ergonomia (Figura 01).

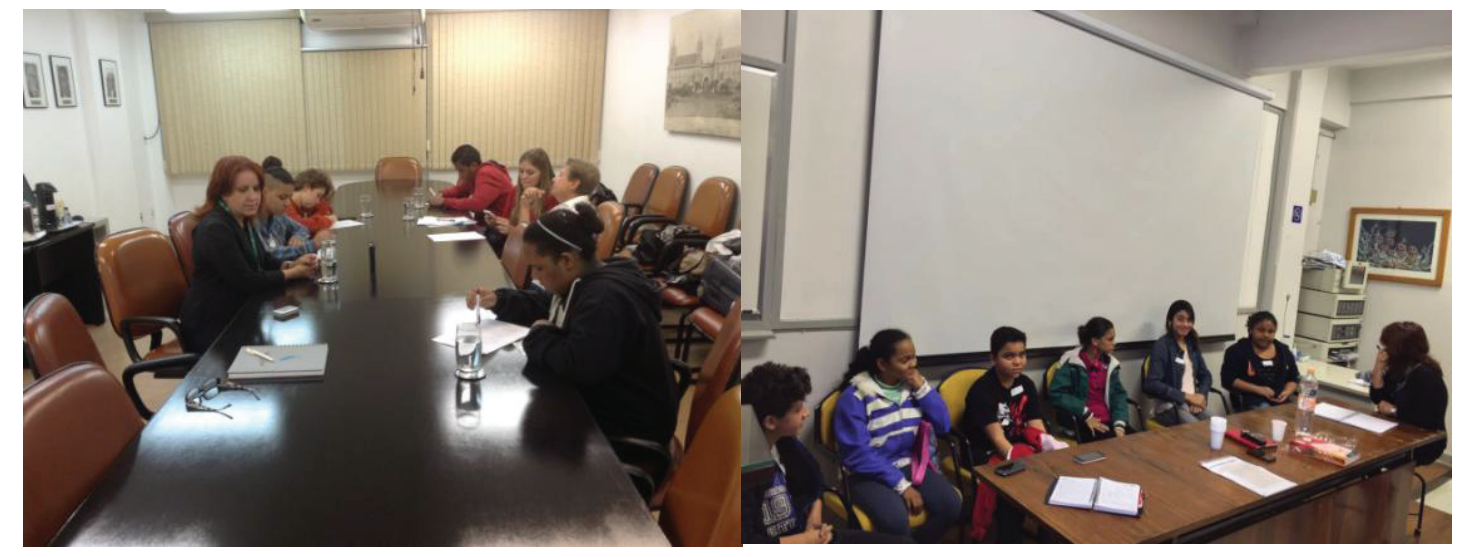

Figura 01: Documentação fotográfica dos grupos focais.

O ambiente de trabalho foi neutro, confortável e continha uma mesa de 10 lugares, ou cadeiras dispostas em círculo, permitindo a interação entre os participantes e possibilitando o contato visual entre os participantes e a pesquisadora. O tempo de cada sessão variou de 45 a 60 minutos, e, no final dela, foi dada uma breve devolutiva aos participantes.

Os encontros foram realizados no fim do período da manhã e no início do período da tarde, tendo sido ofertada aos participantes e aos seus responsáveis alimentação após a sessão. Além disto, cada adolescente 
recebeu um livro "Eu, Super" do autor Eric Peleias, como brinde ético no final da sessão. Foram respeitadas as eventuais limitações. Bem como foi disponibilizada cobertura de custo de transporte para os que solicitaram e não tinham condições de prover (Figura 02).

Todos os custos foram cobertos com verba própria da pesquisadora principal, sem qualquer conflito de interesses.

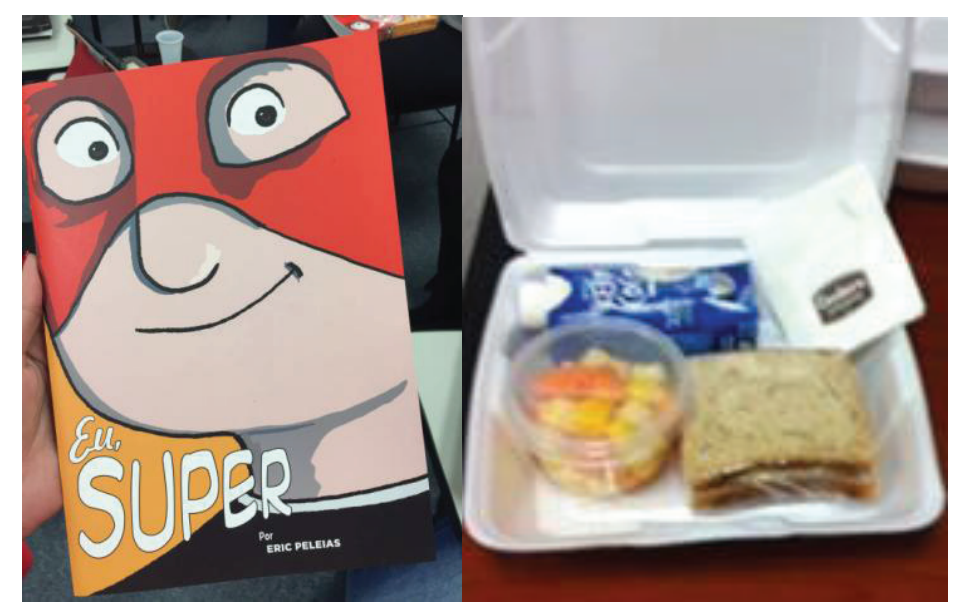

Figura 02: Imagem do livro infanto-juvenil "Eu, Super" e da alimentação oferecidos como brindes éticos aos participantes.

A coordenação dos grupos focais foi feita pela pesquisadora com apoio de um segundo pesquisador auxiliar que teve a função de realizar apontamentos complementares, colaborando com o preenchimento do caderno de campo. Esta ferramenta objetivou auxiliar a transcrição dos áudios dos grupos focais. O pesquisador auxiliar forneceu apoio logístico, sem qualquer interferência na coleta e produção de dados.

A participação direta do pesquisador principal como moderador dos grupos focais foi essencial para eventualmente introduzir questões adicionais pertinentes a pesquisa, ou para estar atendo à comunicação não verbal entre os participantes, explorando-a. Sínteses intermitentes foram feitas, com o objetivo de esclarecer aos demais participantes as qualificações que foram surgindo durante as sessões. ${ }^{(37)}$ 
Cada grupo focal seguiu o roteiro pré-determinado:

1. Participantes e responsáveis foram recebidos pela equipe de pesquisa e levados a sala na qual se realizaria o grupo focal.

2. Abertura com apresentação da equipe de coordenação, boas vindas e definição de objetivos.

3. Esclarecimento sobre o método de pesquisa.

4. O TCLE - Termo de Consentimento Livre e Esclarecido foi distribuído e eventuais dúvidas foram respondidas.

5. Os responsáveis também receberam um breve questionário sócio demográfico e o questionário de Resiliência

6. Respeitou-se o tempo de leitura, preenchimento e assinatura.

7. Uma vez finalizada esta etapa, apenas os sujeitos de pesquisa permaneceram no local.

8. Apresentação dos participantes entre si e entrega de crachás e formulários de identificação individual.

9. Estabelecimento do contrato grupal com definição de regras de convivência, assiduidade, atrasos, desistência e sigilo compartilhado.

10. Estabelecimento das regras do debate, enfatizando que não se busca consenso e que divergências podem ocorrer livremente.

11. Consentimento do grupo para gravação bem como garantir o sigilo do material produzido.

12. O grupo focal seguiu um roteiro semiestruturado com as perguntas:

- Em que sua vida é diferente em relação aos outros adolescentes?

- Como sua família e amigos lidam com as questões relativas à sua saúde?

- Como você se sente em relação ao seu tratamento? 
- Como você vê seu corpo?

- O que faz você sentir melhor? O que te alegra?

- Quais são seus projetos para o futuro?

- Que conselho você daria aos profissionais de saúde envolvidos em seu tratamento?

13. Síntese da sessão resumindo os resultados do grupo e com auxílio do segundo pesquisador oferecendo devolutiva ao grupo e garantia de acesso aos resultados finais do estudo.

14. Encerramento e agradecimentos e eventual agendamento de nova sessão.

Os questionários que compõem a fase quantitativa (Fase II) da pesquisa foram aplicados aos participantes dos grupos, de forma individual imediatamente antes da realização da sessão de grupo focal. Foram utilizados dois métodos de registro de dados. Cada sessão de discussão foi gravada em áudio, um gravador manual, e outro gravador do aparelho marca Ipad®. Anotações manuais também foram feitas pelo pesquisador, incluindo reações não verbais e dinâmicas do grupo. Após cada sessão, as gravações de áudio, complementadas pelas notas manuais, foram usadas para gerar a transcrição da sessão.

As perguntas dos grupos focais seguiram um roteiro semiestruturado baseadas no Questionário de Percepção de Doença - versão abreviada ${ }^{(38)}$ e nas características da Síndrome da Adolescência Normal. ${ }^{(31)}$ O Questionário de Percepção de Doença consiste numa escala projetada para avaliar de forma sucinta e as representações cognitivas e emocionais da doença. Ele foi desenvolvido em adultos a partir da descrição anterior de Leventhal $^{(39)}$ dos componentes da representação da doença de forma que pudesse se adaptar a diferentes condições crônicas de saúde, baseado em cinco perspectivas:

1. Identidade - os sintomas que o paciente associa à doença

2. Causas- ideias pessoais sobre etiologia 
3. Linha do tempo - a duração percebida da doença

4. Consequências - efeitos esperados e resultados

5. Controle e cura - como se controla ou recupera da Doença ${ }^{(40)}$

As características da Síndrome da Adolescência Normal descritas por Aberastury e Knobel como um conjunto de sintomas sob enfoque psicanalítico de seus autores são: ${ }^{(31)}$

1. Busca pela identidade do ser adulto e de si mesmo

2. Necessidade de fantasiar e crescer intelectualmente

3. Separação progressiva dos pais

4. Tendência a viver em grupos

5. Contradições nas manifestações de conduta

6. Crises religiosas

7. Atitude social reivindicatória

8. Alternância de humor

9. Evolução sexual

10. Deslocações no tempo.

Entretanto, não encontramos na literatura algum instrumento válido que inclua as especificidades da adolescência, por esta razão as perguntas norteadoras foram fundamentadas desta forma.

\section{Análise de dados qualitativos}

O método de análise dos dados coletados nos grupos focais foi o de Análise de Conteúdo. Análise de Conteúdo consiste num conjunto de técnicas e procedimentos sistemáticos e objetivos de descrição dos conteúdos, de forma que permitam a categorização, a elaboração de inferências e a interpretação e discussão dos dados. ${ }^{(41)}$ 
A análise dos dados qualitativos seguiu a proposição de $\operatorname{Bardin}^{(41)}$ : Flick $^{(42)}$ e Gibbs ${ }^{(43)}$ :

1. Preparação do material - transcrição das entrevistas gravadas e anotações

2. Pré -análise -realização de leituras

3. Categorização - destaque de assuntos por relevância e/ou por repetição

4. Validação externa - discussão com o grupo de pesquisa e debate dos resultados

5. Apresentação descritiva dos resultados divididos em grandes temas e exemplos de discursos com citações ilustrativas das falas.(35)

Este estudo cumpriu os critérios do Critical Appraisal Skill Programme $(\mathrm{CASP})^{(44)}$. O CASP é uma instituição que desenvolve ferramentas e oferece treinamentos para a avaliação da pesquisa no Reino Unido, com um módulo específico para pesquisa qualitativa. O estudo foi também submetido aos critérios do Consolidated Criteria for Reporting Qualitative Research (COREQ) que consiste de uma lista de 32 itens que são necessários para uma pesquisa qualitativa de qualidade. ${ }^{(45)}$

\section{$\underline{\text { Coleta de dados da Fase II }}$}

Na Fase II do estudo foram coletados dados do perfil sócio demográfico, da percepção da qualidade de vida e resiliência, a partir de questionários autoinformes.

1. Questionário sócio demográfico (Anexo II).

2. WHOQOL-BREF (Anexo III).

3. RS - 14-Escala de Resiliência de Wagnild \& Young (Anexo IV).

Os dados de diagnóstico foram colhidos do prontuário do participante. A coleta de dados utilizou um questionário com variáveis sobre características sociodemográficas (sexo, idade, escolaridade) e comportamentais. Todos os questionários foram aplicados pela autora. 


\section{Avaliação da Qualidade de Vida}

A avaliação da qualidade de vida foi realizada por meio do WHOQOLBREF e da autoavaliação da qualidade de vida. Este instrumento foi validado no Brasil por Fleck et al em 1999, no Centro WHOQOL para o Brasil, na Universidade Federal do Rio Grande do Sul. O WHOQOL-BREF consta de 26 questões, sendo duas avaliadas individualmente e 24 distribuídas em 4 domínios (Quadro 1). ${ }^{(12)}$

\begin{tabular}{|l|l|}
\hline \multicolumn{2}{|l|}{ Quadro 1- Domínios do WHOQOL-BREF } \\
\hline Domínio Saúde Física & $\begin{array}{l}\text { Avalia a qualidade de vida em relação a } \\
\text { aspectos físicos como energia individual, } \\
\text { fadiga, dependência de substâncias } \\
\text { medicinais e ajuda médica, dor, desconforto, } \\
\text { sono e repouso e capacidade de trabalho. }\end{array}$ \\
\hline Domínio Psicológico & $\begin{array}{l}\text { Avalia a qualidade de vida em relação } \\
\text { imagem corporal e aparência, sentimentos } \\
\text { negativos e positivos, autoestima, } \\
\text { espiritualidade/religião/crenças pessoais e } \\
\text { pensamento, aprendizagem, memória e } \\
\text { concentração. }\end{array}$ \\
\hline Domínio Relações & $\begin{array}{l}\text { Avaliam relações interpessoais e sociais, } \\
\text { redes de suporte e atividade sexual. }\end{array}$ \\
\hline Dociais & $\begin{array}{l}\text { Avalia a mobilidade, atividades diárias, } \\
\text { necessidade de medicamentos, recursos } \\
\text { financeiros, liberdade e segurança física, } \\
\text { cuidados de saúde e sociais: disponibilidade e } \\
\text { qualidade do ambiente doméstico, } \\
\text { oportunidades para adquirir novas } \\
\text { informações e habilidades, participação e } \\
\text { oportunidades de recreação/lazer, ambiente } \\
\text { físico (poluição/ruído/trânsito/ clima) e } \\
\text { transporte e capacidade para o trabalho. }\end{array}$ \\
\hline Domín & \\
&
\end{tabular}


Tal avaliação se concentra no que é percebido pelos entrevistados, e não é um meio de medição de todos os sintomas de forma detalhada, doenças ou condições, mas dos efeitos das intervenções da doença e saúde na qualidade de vida. A avaliação de qualidade de vida é verificada pelas médias que variam de 26 a 130 pontos e de 0 a 100 para cada domínio, não existindo um ponto de corte que indique médias desejáveis, contudo, quanto mais altas as médias, melhor percepção da qualidade de vida tem o indivíduo.

Dados perdidos foram tratados conforme instruções de utilização do WHOQOL-BREF: quando mais de $20 \%$ dos dados estivessem ausentes de uma avaliação, a avaliação seria descartada. Quando um item estivesse faltando, seria substituído pela média de outros itens do domínio. ${ }^{(46)}$

\section{Avaliação da Resiliência}

A resiliência foi avaliada por meio do questionário RS-14 (Resilience Scale) - Escala de Resiliência de Wagnild \& Young, o primeiro e mais usado instrumento para medir resiliência. Apresenta 25 afirmações em escala do tipo Likert de sete pontos. Existe uma versão abreviada, a RS-14, com 14 questões, agrupadas em cinco domínios (Quadro 2)

\begin{tabular}{|l|l|}
\hline \multicolumn{2}{|l|}{ Quadro 2- Domínios do RS - 14 } \\
\hline Autoconfiança & $\begin{array}{l}\text { Avaliação subjetiva que uma pessoa faz de si mesma } \\
\text { como sendo intrinsecamente positiva ou negativa em } \\
\text { algum grau. Mede a crença em si mesmo e o } \\
\text { conhecimento de suas qualidades pessoais. Questões: 1, } \\
5,7,12,14 \text {. Varia de 5 a } 35 \text { pontos. }\end{array}$ \\
\hline Sentido da Vida & $\begin{array}{l}\text { Questionamento filosófico acerca do propósito e } \\
\text { significado da existência humana. Mede o reconhecimento } \\
\text { do indivíduo sobre o propósito da vida. Pessoas com altos } \\
\text { escores nesse domínio geralmente dizem que têm uma } \\
\text { razão para acordar pela manhã. Questões: 2,9,13. Varia } \\
\text { de 3 a 21 pontos }\end{array}$ \\
\hline Serenidade & $\begin{array}{l}\text { Estado de calma ou tranquilidade, ausência de } \\
\text { perturbações ou agitação. Mede quanto à perspectiva de }\end{array}$ \\
\hline
\end{tabular}




\begin{tabular}{|l|l|}
\hline & $\begin{array}{l}\text { vida e das experiências é equilibrada. Pessoas com altos } \\
\text { escores nesse domínio geralmente têm bom senso de } \\
\text { humor. Questões 3,10. Varia de } 2 \text { a 14 pontos. }\end{array}$ \\
\hline Perseverança & $\begin{array}{l}\text { Capacidade de manter esforços, mesmo frente a } \\
\text { dificuldades, falhas ou oposições. Mede o ato de persistir } \\
\text { apesar de adversidades ou desencorajamentos. Questões } \\
6 \text { e 8. Varia de 2 a 14 pontos. }\end{array}$ \\
\hline Autossuficiência & $\begin{array}{l}\text { Estado de não necessitar ajuda, apoio ou interação de } \\
\text { outros, para sobreviver. Mede o senso de singularidade } \\
\text { do indivíduo e de liberdade. Questões } 4 \text { e 11. Varia de } 2 \text { a } \\
14 \text { pontos. }\end{array}$ \\
\hline
\end{tabular}

Para a interpretação dos resultados do RS-14 são calculados os escores para cada domínio, que é igual à somatória de questões de cada domínio. Um escore total é obtido pela somatória de todas as questões e determina a intensidade de resiliência, que varia de alta a muito baixa, Quanto maior o valor, maior a resiliência ${ }^{(47,48)}$ (Quadro 3).

\begin{tabular}{|l|c|}
\hline \multicolumn{2}{|l|}{ Quadro 3- Intensidade de Resiliência - escore global do RS - 14.} \\
\hline Resiliência & Escore global \\
\hline Alta & $81-98$ \\
\hline Moderadamente Alta & $74-81$ \\
\hline Nem Alta nem baixa & $65-73$ \\
\hline Mais para baixa & $57-64$ \\
\hline Baixa & $14-56$ \\
\hline Muito baixa & \\
\hline
\end{tabular}




\section{Análise de dados quantitativos}

Os dados quantitativos da fase II foram submetidos à análise estatística descritiva, utilizando o pacote estatístico Statistical Package for the Social Sciences (SPSS), versão 22.

As variáveis que corresponderam a distribuição normal (paramétricas) foram expressas em média e desvio padrão (DP) e as não paramétricas foram expressas em mediana e percentil 25-75 [P25-P75]. Os dados categóricos foram descritos em valor absoluto e porcentagem da amostra total.

Para comparar medidas de tendência central dos domínios dos questionários analisados de acordo com o sexo, faixa etária categorizada em menor que quinze anos e maior/igual a 15 anos, ano letivo perdido, escolaridade dos pais, categorizada em menor/igual a nove anos e acima de nove anos, foi utilizado o teste para duas amostras independentes, MannWhitney U-teste, porque a maioria dos domínios tiveram distribuição não normal. 


\section{Resultados}

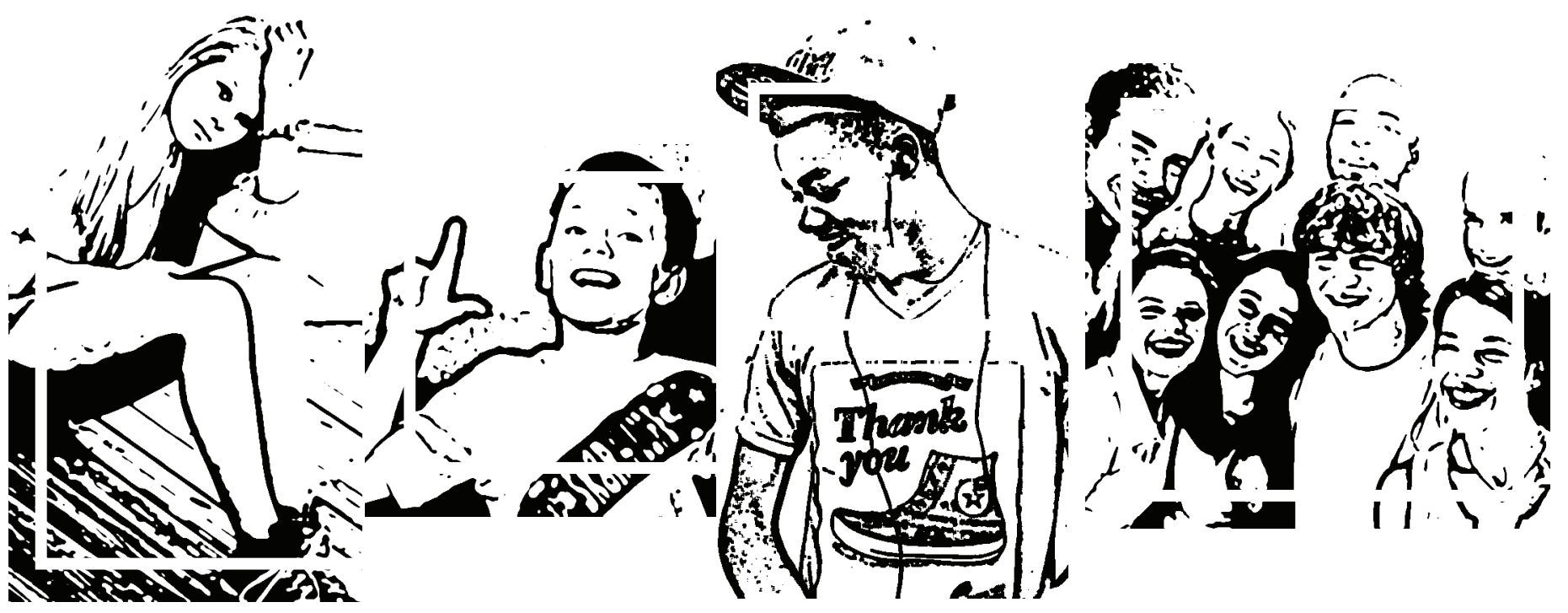




\section{RESULTADOS}

\section{Caracterização da amostra}

No total, foram selecionados a partir do banco de registros do Ambulatório do Departamento de Pediatria da Faculdade de Ciências Médicas da Santa Casa de São Paulo, pacientes com perfil para compor a amostra. E feitos efetivamente 60 convites telefônicos para participação nos grupos focais. Dos quais resultaram 43 aceitações e 31 participações. Houve 12 faltas. As razões de recusa foram: falta de verba e/ou logística para o deslocamento até o hospital, já que alguns deles residem distantes ou até em cidades vizinhas, impossibilidade de faltar à escola e/ou do responsável ausentar-se do trabalho e responsável doente (Figura 03 ).

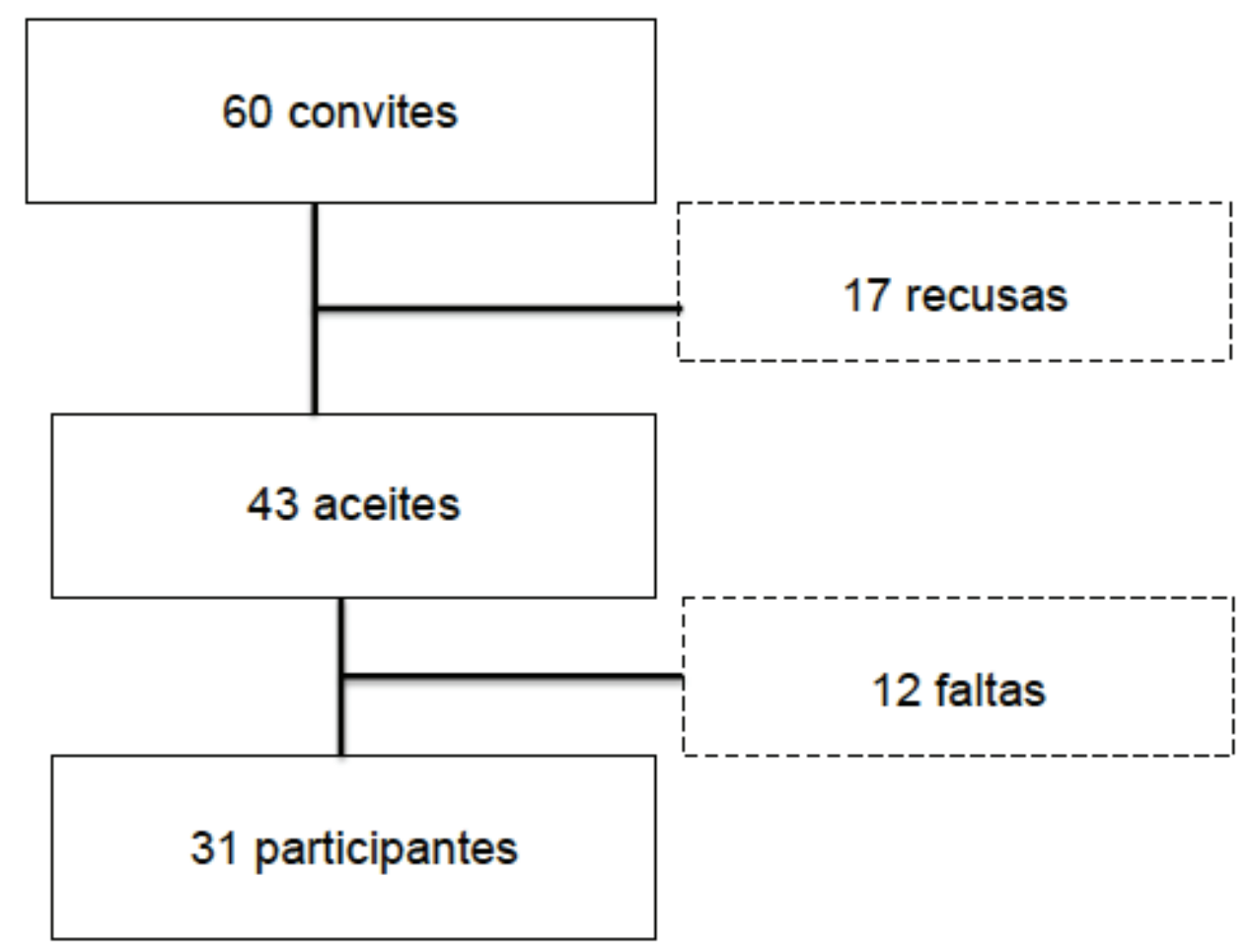

Figura 03: Fluxograma de perdas do estudo

Participaram deste estudo 31 adolescentes em seguimento regular no Ambulatório de Especialidades Pediátricas do Departamento de Pediatria da Faculdade de Ciências Médicas da Santa Casa de São Paulo, com idade variando de 12 a 18 anos, sendo a média de 15,1 $\pm 1,5$ anos. Foram nomeados adolescentes médios aqueles com idade inferior a 15 anos, nesta amostra 
eram nove adolescentes (29,03\%) e 22 adolescentes (70,97\%), adolescentes tardios, com idade igual ou maior de 15 anos. Em relação ao sexo, 20 adolescentes eram do sexo feminino $(64,5 \%)$ e 11 do sexo masculino $(35,5 \%)$.

Entre os 31 participantes, oitos (25,8\%) revelaram ter um ano de atraso escolar, entre estes dois não relacionam a perda ao processo de doença e tratamento. Três dos participantes trabalhavam além de estudar, um como jovem aprendiz, um como estagiário e um com emprego formal registrado na CLT (Consolidação das Leis do Trabalho).

No que ser refere ao diagnóstico etiológico dos participantes, observaram-se 12 doenças. (Tabela 1)

Tabela 1: Distribuição do diagnóstico etiológico dos participantes do estudo.

\begin{tabular}{lcc}
\hline Doenças & Participantes & Porcentagem \\
\hline Diabetes tipo 1 & 10 & $31,25 \%$ \\
Síndrome Nefrótica & 5 & $16,13 \%$ \\
Cardiopatia & 5 & $16,13 \%$ \\
Diabetes tipo 2 & 1 & $3,22 \%$ \\
Lúpus Eritematoso Sistêmico & 3 & $9,68 \%$ \\
Fibrose Cística & 2 & $6,45 \%$ \\
Artrite & 1 & $3,22 \%$ \\
Hipertensão & 1 & $3,22 \%$ \\
Esclerodermia & 1 & $3,22 \%$ \\
Anemia Falciforme & 1 & $3,22 \%$ \\
Alergia Alimentar & 1 & $3,22 \%$ \\
\hline
\end{tabular}


Quanto ao grau de escolaridade os adolescentes frequentavam o ensino fundamental e médio (Tabela 2). Dos 31 adolescentes participantes do estudo, oitos $(25,80 \%)$ revelaram ter perdido algum ano letivo e destes, dois deles (25\%) não relacionaram a repetência à sua doença.

Tabela 2: Distribuição do grau de escolaridade da amostra.

\begin{tabular}{llc}
\hline Ano escolar & $\mathrm{n}$ & $\%$ \\
\hline $6^{\circ}$ ano do ensino fundamental & 2 & 6,45 \\
$7^{\circ}$ anos do ensino fundamental & 1 & 3,22 \\
$8^{\circ}$ ano do ensino fundamental & 5 & 16,13 \\
$9^{\circ}$ ano do ensino fundamental & 5 & 16,13 \\
$1^{\circ}$ ano do ensino médio & 9 & 29,03 \\
$2^{\circ}$ ano do ensino médio & 6 & 19,35 \\
$3^{\circ}$ ano do ensino médio & 3 & 9,68 \\
\hline
\end{tabular}

Entre os 31 participantes, apenas seis deles (19,35\%) nunca foram tratados em regime de internação hospitalar. O número de internações variou de um a sete períodos. O tempo de internação variou de dois a 60 dias.

Quanto ao uso de medicações, apenas 6,4\% não usam medicamento. Os pacientes estão em seguimento e são aderentes ao tratamento.

\section{Avaliação da Qualidade de Vida}

A autoavaliação da qualidade de vida foi analisada atribuindo-se uma nota de zero a dez, sendo zero pior qualidade de vida possível. Entre os participantes a mediana foi 8,00 e o intervalo interquartílico 3,00. Considerando a qualidade de vida avaliada por escore geral na autoavaliação, não se 
observou diferença estatisticamente significativa quanto a idade, sexo e ano letivo perdido (Tabela 3).

Tabela 3: Qualidade de vida por escore geral na autoavaliação por idade, sexo e ano letivo perdido.

\begin{tabular}{lccc}
\hline $\begin{array}{l}\text { Qualidade } \\
\text { De Vida Geral }\end{array}$ & $\mathrm{N}(\%)$ & $\begin{array}{c}\text { Mediana } \\
{[\mathrm{P} 25-\mathrm{P} 75]}\end{array}$ & $\mathrm{p}$ \\
\hline$<15$ anos & $9(29,03 \%)$ & 8,00 & 0,848 \\
& & {$[5,5-9,5]$} & \\
$\geq 15$ anos & $22(70,97 \%)$ & 8,00 & \\
& & {$[6-9]$} & \\
Masculino & $11(35,5 \%)$ & 8 & 0,403 \\
& & {$[8-9]$} & \\
Feminino & $20(64,5 \%)$ & 7,5 & \\
Perda de ano & $8(25,8 \%)$ & $7,50-9]$ & 0,550 \\
letivo & & {$[6-8,75]$} & \\
Sem perda de & $23(74,2 \%)$ & 8,00 & {$[6-9]$} \\
ano letivo & & & \\
\hline Teste Mann-Whitney & & \\
\end{tabular}

Teste Mann-Whitney ${ }^{*} p<0,05$.

A avaliação da qualidade de vida por meio do questionário da Organização Mundial de Saúde (WHOQOL-BREF) não revelou diferença estatisticamente significativa quanto a sexo ou ano escolar perdido (Tabela 4 e Tabela 5). 
Tabela 4: Mediana dos escores dos domínios do WHOQOL-BREF de acordo com sexo.

\begin{tabular}{|c|c|c|c|}
\hline & Masculino & Feminino & \\
\hline \multirow{2}{*}{ Domínios } & Mediana & Mediana & $p$ \\
\hline & [P25-P75] & [P25-P75] & \\
\hline $\mathrm{N}(\%)$ & $11(35,5 \%)$. & $20(64,5 \%)$ & \\
\hline \multirow[t]{2}{*}{ Domínio Físico } & 71,43 & 64,28 & 0,104 \\
\hline & {$[64,28-75]$} & {$[57,14-71,43]$} & \\
\hline \multirow[t]{2}{*}{ Domínio Psicológico } & 79,17 & 62,50 & 0,072 \\
\hline & {$[58,33-83,33]$} & {$[55,20-73,96]$} & \\
\hline \multirow[t]{2}{*}{ Domínio Relações Sociais } & 75,00 & 75,00 & 0,730 \\
\hline & {$[58,33-91,66]$} & {$[66,6-75]$} & \\
\hline \multirow[t]{2}{*}{ Domínio Ambiente } & 50,00 & 45,31 & 0,670 \\
\hline & {$[21,87-78,12]$} & {$[16,40-64,84]$} & \\
\hline
\end{tabular}

Teste Mann-Whitney ${ }^{*} \mathrm{p}<0,05$.

Tabela 5: Mediana dos escores dos domínios do WHOQOL-BREF por ano letivo perdido.

\begin{tabular}{lccc}
\hline \multirow{2}{*}{ Domínios } & Sim & Não & \\
& Mediana & Mediana & $\mathrm{p}$ \\
& {$[\mathrm{P} 25-\mathrm{P} 75]$} & {$[\mathrm{P} 25-\mathrm{P} 75]$} & \\
\hline $\mathrm{N}(\%)$ & $8(25,8 \%)$ & $23(74,2 \%)$ & \\
\hline Domínio Físico & 62,50 & 67,86 & 0,437 \\
& {$[58,03-69,64]$} & {$[57,14-71,42]$} & \\
Domínio Psicológico & 62,50 & 70,83 & 0,237 \\
\hline
\end{tabular}




$$
\text { [58,33-66,66] [58,33-83,33] }
$$

Domínio Relações Sociais

$$
75,00
$$

75,00

0,842

[68,74-75,00]

[58,33-83,33]

Domínio Ambiente

$$
21,87
$$

56,25

0,110

[19,53-50,00]

$[18,75-68,75]$

Teste Mann-Whitney ${ }^{\star} p<0,05$.

Entre os adolescentes dos dois grupos etários, isto é, menores de 15 anos e maiores de 15 anos inclusive, encontrou-se diferença estatisticamente significativa apenas no Domínio Relações Sociais, os adolescentes com idade inferior a 15 anos têm escores mais elevados neste domínio (Tabela 6).

Tabela 6: Mediana dos escores dos domínios do WHOQOL-BREF por grupo etário

\begin{tabular}{lccc}
\hline \multirow{2}{*}{ Domínios } & $<15$ anos & $\geq 15$ anos & \\
& Mediana & Mediana & $p$ \\
& {$[\mathrm{P} 25-\mathrm{P} 75]$} & {$[\mathrm{P} 25-\mathrm{P} 75]$} & \\
\hline $\mathrm{N}$ & $9(29,03 \%)$ & $22(70,97 \%)$ & \\
\hline Domínio Físico & 67,86 & 64,28 & 0,915 \\
& {$[50,00-73,21]$} & {$[57,14-71,42]$} & \\
Domínio Psicológico & 62,5 & 66,66 & 0,848 \\
& {$[60,42-79,17]$} & {$[58,33-75,00]$} & \\
Domínio Relações Sociais & 83,33 & 70,83 & $0,04^{*}$ \\
& {$[75,00-100,00]$} & {$[58,33-75,00]$} & \\
Domínio Ambiente & 56,25 & 23,43 & 0,064 \\
& {$[45,31-71,87]$} & {$[15,62-63,28]$} & \\
\hline
\end{tabular}

Teste Mann-Whitney ${ }^{*} \mathrm{p}<0,05$. 


\section{Avaliação da Resiliência(48)}

A avaliação da resiliência dos adolescentes avaliada por meio dedo questionário validado RS-14 Escala de Resiliência de Wagnild \& Young.

Um escore total é obtido pela somatória de todas as questões e determina a intensidade de resiliência, que varia de alta a muito baixa.

$\mathrm{Na}$ amostra do estudo, o escore obtido, com mediana 73 [67-78], localiza-se entre mais para baixa e nem alta nem baixa (Tabela 7).

Tabela 7: Mediana dos escores de resiliência global e por domínios.

\begin{tabular}{lc}
\hline $\begin{array}{l}\text { Resiliência (escore mínimo - escore } \\
\text { máximo) }\end{array}$ & Mediana [P25-P75] \\
\hline Escore Global (14-98) & $73[67-78]$ \\
Domínio Autoestima (5-35) & 24 [20-27] \\
Domínio Sentido da Vida (3- 21) & $17[14-19]$ \\
Domínio Serenidade (2-14) & $11[10-13]$ \\
Domínio Perseverança (2-14) & $11[8-12]$ \\
Domínio Autossuficiência (2-14) & $12[9-13]$ \\
\hline
\end{tabular}

Considerando a resiliência comparada entre os sexos, nenhuma diferença estatisticamente significativa foi encontrada. Também não foram identificadas diferenças significativas em relação as idades dos participantes

Quando analisada a resiliência em relação a perda de ano letivo, observamos diferença estatisticamente significativa, $p=0,023$. Os adolescentes que não perderam anos escolares têm escores mais elevados de Resiliência (Tabela 8). 
Tabela 8: Mediana dos escores de Resiliência Global, por sexo, idade e ano letivo perdido.

\begin{tabular}{lccc}
\hline Resiliência & $\mathrm{N}$ & $\begin{array}{c}\text { Mediana } \\
{[\mathrm{P} 25-\mathrm{P} 75]}\end{array}$ & $\mathrm{p}$ \\
\hline Masculino & $11(35,5 \%)$ & 73,00 & \\
Feminino & $20(64,5 \%)$ & $768,00-78,00]$ & 0,792 \\
& & 73,5 & \\
$<15$ anos & $9(29,03 \%)$ & 76,00 & \\
& & {$[69,50-84,00]$} & \\
$\geq 15$ anos & $22(70,97 \%)$ & 72,50 & 0,188 \\
& & {$[62,25-77,25]$} & \\
Perda de ano letivo & $8(25,8 \%)$ & 67,50 & \\
& & {$[58,03-69,64]$} & \\
Sem perda de ano & $23(74,2 \%)$ & 75,00 & $0,023^{*}$ \\
letivo & & {$[57,14-71,42]$} & \\
\hline
\end{tabular}

Teste Mann-Whitney ${ }^{*} p<0,05$.

A escolaridade dos pais ou responsáveis avaliada por meio de questionário sociodemográfico, distribuiu-se entre ensino fundamental incompleto até ensino superior completo (Tabela 9).

Tabela 9: Distribuição do grau de escolaridade dos pais ou responsáveis dos respondentes.

\begin{tabular}{lcc}
\hline Ano escolar & $\mathrm{N}$ & $\%$ \\
\hline Ensino fundamental & 10 & 32,26 \\
incompleto & & \\
Ensino fundamental completo & 4 & 12,90 \\
\hline
\end{tabular}




\begin{tabular}{lcc}
\hline Ensino médio incompleto & 2 & 6,45 \\
Ensino médio completo & 12 & 38,71 \\
Ensino superior completo & 3 & 9,68 \\
\hline
\end{tabular}

Para fins de comparação optou-se por avaliar dois grupos. Um deles com até nove anos de escolaridade que corresponde ao ensino fundamental completo e outro grupo com escolaridade de nove anos ou mais. Comparando os dados de resiliência, qualidade de vida e cada um dos seus domínios dos adolescentes, com a escolaridade dos pais, não observamos diferença estatisticamente significativa (Tabela 10).

Tabela 10: Mediana dos escores de resiliência global, qualidade de vida, domínios por escolaridade dos pais.

\begin{tabular}{lccc}
\hline & $\begin{array}{c}\leq 9 \text { anos de } \\
\text { escolaridade }\end{array}$ & $\begin{array}{c}>9 \text { anos de } \\
\text { escolaridade }\end{array}$ & $p$ \\
\hline Mediana & $\begin{array}{c}\text { Mediana } \\
{[\text { P25-P75] }}\end{array}$ & \\
\hline $\mathrm{N} 25-\mathrm{P} 75]$ & \\
\hline Qualidade de vida & $14(45,16 \%)$ & $17(54,84 \%)$ & \\
\hline Domínio Físico & 8,00 & 8,00 & 0,824 \\
& {$[6,75-9,00]$} & {$[6,00-9,00]$} & \\
Domínio Psicológico & 64,29 & 64,29 & 0,508 \\
& {$[56,25-71,43]$} & {$[57,14-73-21]$} & \\
Domínio Relações Sociais & 66,66 & 62,50 & 0,984 \\
& {$[61,46-75,00]$} & {$[56,25-83,33]$} & \\
Domínio Ambiente & 75,00 & 75,00 & 0,424 \\
& {$[66,66-79,16]$} & {$[58,33-79,16]$} & \\
& 37,50 & 59,37 & 0,462 \\
& {$[21,87-57,03]$} & {$[15,62-73,43]$} & \\
\hline
\end{tabular}




\begin{tabular}{lccc}
\hline Resiliência & 73,00 & 73,00 & 0,984 \\
& {$[67,75-77,25]$} & {$[64,5-79,50]$} &
\end{tabular}

Teste Mann-Whitney ${ }^{*} \mathrm{p}<0,05$.

\section{Análise dos Dados dos Grupos Focais}

A análise dos dados qualitativos foi realizada separadamente para cada uma das perguntas norteadoras do grupo focal.

Do conjunto de discursos referentes à primeira pergunta "Em que sua vida é diferente em relação aos outros adolescentes? ", emergiram duas categorias principais: limitação e desenvolvimento pessoal.

Os discursos dos participantes foram coincidentes ao explicar as diferenças de suas vidas em relação a vida de outros adolescentes, revelando situações pelas quais passam e os adolescentes sem doença crônica, não. Inseridos na categoria limitação o uso de medicações, horários e vias de administração foram os itens definidos. Mas não necessariamente manifestados como uma situação negativa, os adolescentes que convivem com a doença há mais tempo consideraram-se adaptados ao tratamento e as limitações que este impõe, conforme o relato a seguir:

“... eu estou acostumada, desde os três anos, então eu cresci tomando insulina" (Fem., 14 anos)

Outro aspecto da limitação consiste na restrição à prática esportiva. Alguns revelaram desconforto físico e dor, outros lamentaram a ausência em esportes mais competitivos, exposição solar, permanência em locais abafados e falta de rendimento físico esperado para o esporte desejado. No entanto, também encontramos respostas ambivalentes neste item, como a resposta apresentada aqui como exemplo:

“... para mim não faz diferença nenhuma, porque tenho vida normal como todo mundo... a única diferença assim que faz é em futsal... em futsal ou qualquer outro esporte. A única coisa que eu não posso fazer é competição, mas tirando 
isso qualquer coisa estou liberado. Então não faz muita diferença..."(Masc., 14 anos)

As questões relativas à restrição alimentar são relevantes no desenvolvimento do adolescente com doença crônica. No momento em que o apetite do adolescente está se modificado em quantidade e em variedade, a refeição representa um encontro social e de pertencimento. Eles não desejam ser diferentes, como o depoimento abaixo ilustra:

"Quando eu vou para algum lugar comer, assim... para o shopping eu não posso comer várias coisas que tem lá... e eles não...” (Fem., 13 anos)

$\mathrm{Na}$ categoria desenvolvimento pessoal, os sujeitos da pesquisa, revelam que a doença e o tratamento os tornaram mais responsáveis, à medida que enfrentam restrição de liberdade, ausência escolar, horários de consultas, internações e medicações, desenvolvem maior disciplina. O exemplo a seguir retrata esta afirmação:

"... eu tenho que controlar a minha alimentação e as minhas medicações, porque o resto se eu tiver maturidade e disciplina suficiente, posso fazer. " (Fem., 15 anos).

As categorias, itens e exemplos de discursos, relativos a primeira pergunta estão descritos na tabela 11.

Tabela 11: Análise qualitativa relativa às respostas da pergunta "Em que sua vida é diferente em relação aos outros adolescentes? "

\begin{tabular}{lll}
\hline Categorias & Itens & Exemplos de Discurso \\
\hline
\end{tabular}

\begin{tabular}{l|l|l}
\hline \multirow{3}{*}{ Medicação } & $\begin{array}{l}\text { “... então... tomo remédio... tomo } 13 \text { tipos de } \\
\text { remédio... para mim não muda nada” (Fem., } \\
15 \text { anos) } \\
\text { "Eu tenho que tomar remédios antes de }\end{array}$ \\
\hline
\end{tabular}




\begin{tabular}{|c|c|c|}
\hline \multirow{4}{*}{ Limitação } & & comer." (Masc., 12 anos) \\
\hline & Dor & $\begin{array}{l}\text { "Por que... mais para mim e para qualquer } \\
\text { outro adolescente que fosse levar, porque tem } \\
\text { que beber muito líquido, e muitas vezes incha } \\
\text { muito e dói... é muito dolorido, muito } \\
\text { desconfortável. Tem atividades que eu não } \\
\text { posso fazer e todo mundo faz...então eu fico } \\
\text { excluída de muitas atividades." (Fem.,17anos) }\end{array}$ \\
\hline & $\begin{array}{l}\text { Prática } \\
\text { esportiva }\end{array}$ & $\begin{array}{l}\text { "Na educação física eu não posso correr, } \\
\text { porque eu sinto falta de ar." (Fem., } 13 \text { anos) } \\
\text { “... não tenho problema com atividade física... } \\
\text { é só eu controlar se eu começar a me sentir } \\
\text { diferente, para ver se a minha glicemia está } \\
\text { muito baixa, muito alta e é só, controlar isso." } \\
\text { (Fem., } 14 \text { anos) } \\
\text { "Eu sinto falta de jogar bola na rua com os } \\
\text { meus amigos... desde que eu tenho Lúpus, eu } \\
\text { não posso tomar sol e também não estou } \\
\text { conseguindo correr porque estou com } \\
\text { problema de joelho e sobrepeso também" } \\
\text { (Masc., 15anos) }\end{array}$ \\
\hline & Dieta & $\begin{array}{l}\text { “... e tenho meus cuidados de não exagerar } \\
\text { no doce, que é uma coisa que também eu não } \\
\text { sou muito chegada no doce...” (Fem. } 14 \text { anos) } \\
\text { “... eu tenho que controlar a minha } \\
\text { alimentação e as minhas medicações, porque } \\
\text { o resto se eu tiver maturidade e disciplina } \\
\text { suficiente, posso fazer. Eu posso lidar com } \\
\text { isso. Eu acho que não preciso me diferenciar } \\
\text { por causa da minha doença.” (Fem., } 15 \text { anos ) }\end{array}$ \\
\hline
\end{tabular}




\begin{tabular}{|c|c|c|}
\hline $\begin{array}{l}\text { Desenvolvimento } \\
\text { Pessoal }\end{array}$ & Disciplina & $\begin{array}{l}\text { “... ah, por causa que tenho que ter a minha } \\
\text { responsabilidade. Por causa que... } \\
\text { antigamente quando saía da escola eu não ia } \\
\text { direto para casa antes...eu ia direto bagunçar } \\
\text { assim, sabe ?, mas agora saio da escola e } \\
\text { vou direto para casa, faço as minhas } \\
\text { responsabilidades...” (Fem., } 14 \text { anos). }\end{array}$ \\
\hline
\end{tabular}

(Continuação Tabela 11)

Os adolescentes quando indagados a respeito de "Como sua família e amigos lidam com as questões relativas à sua saúde? ", demonstraram importância relevante dos seus cuidadores e responsáveis, categorizada aqui como cuidado parental.

Conforme a adolescência progride, um afastamento dos pais é esperado; neste grupo de adolescentes, demonstrou-se que a participação dos pais ou responsáveis no cuidado relativo à saúde ainda é bastante significativa. Este cuidado foi visto como uma vantagem, garantindo suporte e atenção, mas por vezes qualificado como superproteção e sentimento de culpa por parte dos adolescentes pelas perdas que seu cuidado impõe aos pais. O exemplo de discurso a seguir demonstra a culpa explicitada pelos adolescentes:

"Hoje ela faltou, amanhã vai ter que faltar de novo porque vou ter que voltar.

Então é chato, porque você se sente culpada pelo sentimento ruim que eles sentem". (Fem., 15 anos)

Outra categoria distinta refere-se ao cuidado dos pares. Os amigos demonstram atenção com os adolescentes, respeitando suas limitações, ajudando-os a se manterem aderidos ao tratamento. Por outro lado, ainda entre pares ocorre provocação, devido às limitações da doença, como os depoimentos que se seguem: 
"Quando eu passo mal, todos meus amigos me ajudam. me levam para diretoria... ai fica aquela multidão querendo ajudar...desesperados"(Fem., 15 anos)

"Mas tem outros que ficam - você quer bolacha? -, para mim... provocando." (Masc., 18 anos)

A ambivalência de sentimentos é constante no comportamento do adolescente, relaciona-se com as transformações globais que ocorrem no indivíduo. Coabitam, nesta fase, desejos ambivalentes de autonomia e de dependência, de se sentirem invisíveis e de sobressair-se (Tabela 12).

Tabela 12: Análise qualitativa relativa à pergunta "Como sua família e amigos lidam com as questões relativas à sua saúde?"

\begin{tabular}{|c|c|c|}
\hline Categorias & Itens & Exemplos de Discurso \\
\hline \multirow{3}{*}{$\begin{array}{l}\text { Cuidado } \\
\text { parental }\end{array}$} & Suporte & $\begin{array}{l}\text { "A minha mãe está sempre no meu } \\
\text { encalço para tomar remédio" (Masc., } 11 \\
\text { anos) } \\
\text { "Porque várias vezes passei mal e meu } \\
\text { pai saiu no meio do expediente do } \\
\text { trabalho dele para me socorrer, me levar } \\
\text { no hospital..." (Masc.,15 anos) }\end{array}$ \\
\hline & Superproteção & $\begin{array}{l}\text { "A minha mãe sempre foi muito } \\
\text { preocupada... e há quatro anos quando } \\
\text { fui diagnosticada a preocupação dela } \\
\text { começou a ser um pouco insuportável" } \\
\text { (Fem., } 15 \text { anos) }\end{array}$ \\
\hline & Culpa & $\begin{array}{l}\text { “... então, é bom porque a minha mãe } \\
\text { ela se preocupa bastante, mas é ruim }\end{array}$ \\
\hline
\end{tabular}




\begin{tabular}{|c|c|c|}
\hline & & $\begin{array}{l}\text { porque eu vejo que por causa de mim } \\
\text { eles vão se desgastando, parece como } \\
\text { se fosse um problema na vida deles. Se } \\
\text { preocupam demais. Às vezes deixam de } \\
\text { fazer alguma coisa por causa de } \\
\text { mim."(Fem., } 15 \text { anos) } \\
\text { "Por exemplo, a minha mãe vive faltando } \\
\text { no Por exemplo, a minha mãe vive } \\
\text { faltando no serviço porque eu tenho que } \\
\text { estar no hospital constantemente. (Fem., } \\
15 \text { anos) }\end{array}$ \\
\hline \multirow[b]{2}{*}{$\begin{array}{l}\text { Cuidado dos } \\
\text { Pares }\end{array}$} & Companheirismo & $\begin{array}{l}\text { "Até tem um amigo meu que lembra que } \\
\text { às } 5 \text { horas é a hora de tomar o remédio } \\
\text { e - e aí, já tomou o remédio?" (Masc., } 15 \\
\text { anos) }\end{array}$ \\
\hline & Constrangimento & $\begin{array}{l}\text { “... às vezes eles ficam: não vai para o } \\
\text { gol não, para não tomar pancada no } \\
\text { peito... não fica na frente da bola...” } \\
\text { (Masc., } 16 \text { anos) } \\
\text { "É... Também tenho um pouco de } \\
\text { vergonha, porque na escola tem que } \\
\text { fazer o dextro? Insulina, lá na sala } \\
\text { mesmo... É chato." (Fem., } 17 \text { anos) }\end{array}$ \\
\hline
\end{tabular}

(Continuação Tabela 12)

As categorias de análise identificadas a partir das respostas da questão "Como você se sente em relação ao seu tratamento?" foram duas: Percepção de doença e tratamento e Resiliência. 
Entre as características da adolescência está a busca de identidade. Nesta fase há muita atenção em si próprio e suas transformações físicas. Qualquer modificação nesta área, causada pela doença ou tratamento pode tomar grandes proporções. O processo do adoecimento e terapêutica conforme avançam durante o desenvolvimento são distintos na faixa etária menor e naqueles que convivem com a doença há mais tempo. Os adolescentes mais recentemente diagnosticados e os mais jovens demonstram por vezes, revolta e desconforto com os sintomas, crises agudas e limitações a que estão sujeitos. Um dos adolescentes nos conta em tom de desabafo:

“... eu queria ter nascido com lúpus já... desde o começo já... teria acostumado de vez, rápido." (Masc., 16 anos)

Os adolescentes mais tardios e/ou convivendo há mais tempo como a doença crônica, parecem aprender com ela, desenvolvendo mecanismos de enfrentamento, tornando-se mais maduros, disciplinados e capazes de controlar as situações, mantendo-se mais como sujeitos ativos no seu tratamento e menos em posição de vítima. A convivência com as condições impostas pela doença vai fazendo parte da vida como vemos no discurso a seguir:

"Você pode sair com seus amigos, você pode viajar com seus amigos... Você pode fazer o que você quiser você só precisa ter maturidade para tomar os seus medicamentos e ter uma alimentação." (Fem., 15 anos)

Outra categoria, a resiliência, emergiu do entendimento que os adolescentes aprendem a usar de seus recursos positivos para enfrentar as adversidades, sendo um fator de proteção para a adaptação às exigências cotidianas da doença e tratamento. Os adolescentes encontram em si mesmos e em sua rede de suporte, estratégias de enfrentamento. Eles desenvolvem disciplina e outras habilidades emocionais, são mais otimistas, aprendem a solicitar ajuda, preservam-se e mantêm o humor (Tabela 13). Como fica demonstrado no discurso de uma das adolescentes: 
“Então é a vida, né? Você não tem muito que fazer... você tem que erguer a cabeça e tentar fazer tudo para melhorar e não ficar só no pensamento negativo" (Fem., 15 anos).

Tabela 13: Análise qualitativa relativa à pergunta "Como você se sente em relação ao seu tratamento? "

\begin{tabular}{l|l|l}
\hline Categorias & Itens & Exemplos de Discurso \\
\hline
\end{tabular}

\begin{tabular}{|c|c|c|}
\hline \multirow[t]{3}{*}{ Percepção } & Revolta & $\begin{array}{l}\text { “Eu fico com raiva mesmo porque eu } \\
\text { não posso fazer o que eu fazia antes, } \\
\text { isto me revolta um pouquinho... eu } \\
\text { queria ter nascido com Lúpus já... } \\
\text { desde o começo já... teria acostumado } \\
\text { de vez, rápido..." (Masc., } 15 \text { anos) } \\
\text { "Por que às vezes cansa. Porque } \\
\text { comigo?" (Fem., } 15 \text { anos) }\end{array}$ \\
\hline & Desconforto & $\begin{array}{l}\text { "Por conta do remédio que eu tomo ele } \\
\text { me incha mais... antes de eu ficar } \\
\text { doente, de tomar esses remédios } \\
\text { todos, eu fazia ginástica então era bem } \\
\text { mais enérgica... então por conta dos } \\
\text { remédios parei com tudo isso... (Fem., } \\
12 \text { anos)" }\end{array}$ \\
\hline & Disciplina & $\begin{array}{l}\text { “... tirando a alimentação e os } \\
\text { medicamentos, acho que o resto você é } \\
\text { capaz de fazer. com maturidade e } \\
\text { disciplina... esportes, viagens e } \\
\text { passeios...” (Fem., } 15 \text { anos) }\end{array}$ \\
\hline
\end{tabular}




\begin{tabular}{l|l|l}
\hline Resiliência & $\begin{array}{l}\text { "Eu tento imaginar pessoas lidando } \\
\text { com coisas piores do que eu, que tem } \\
\text { restrições piores que as minhas." } \\
\text { (Fem., } 15 \text { anos) }\end{array}$ \\
\hline \multirow{E}{*}{ Enfrentamento } & $\begin{array}{l}\text { "Eu posso lidar com isso... Eu acho que } \\
\text { eu não preciso me diferenciar por } \\
\text { causa da minha doença" (Fem., 15 } \\
\text { anos) } \\
\text { "A doença não te prende a um certo } \\
\text { padrão" (Fem.,15 anos) }\end{array}$ \\
\hline
\end{tabular}

(Continuação Tabela 13)

A questão "Como você vê seu corpo?" tem foco na aparência como um fator importante no ser humano em transformação corporal tão expressiva quanto na fase da adolescência. A categoria imagem corporal foi a dominante. O tratamento e o grau de controle da doença influenciam a aparência dos adolescentes. Este aspecto é demonstrado na fala do adolescente:

"... eu no começo chorava quando me olhava no espelho. Tomava $40 \mathrm{mg}$ de corticóides... eu fiquei muito inchado. Aí quando me olhava no espelho .?. Agora hoje nem... nem ligo mais tanto assim. (Masc., 15 anos) "

A visão real contrasta com a idealizada, prejudicando a autoestima e gerando isolamento, constrangimento e situações de rejeição. Como se observa no seguinte exemplo:

"Ah, vou sair com meus amigos, porque quando eu estou inchada, eu me sinto muito feia, entendeu? Então você fica... não quero aparecer na frente dos meus amigos assim... tenho vergonha..." (Fem., 15 anos) 
Embora ligada a imagem corporal, a categoria autoestima destaca-se por estar relacionada a sentimentos que vão além da aparência, como a sensação de segurança e comportamentos de autoexclusão (Tabela 14).

Tabela 14: Análise qualitativa das respostas relativa à pergunta "Como você vê seu corpo?"

\begin{tabular}{l|l|l}
\hline Categorias & Itens & Exemplos de Discurso \\
\hline
\end{tabular}

\begin{tabular}{|c|c|c|}
\hline \multirow[t]{2}{*}{$\begin{array}{l}\text { Imagem } \\
\text { corporal }\end{array}$} & Constrangimento & $\begin{array}{l}\text { “No começo também tomava corticóides } \\
\text { e inchei bastante. Não queria sair do } \\
\text { quarto... que eu sentia vergonha... } \\
\text { (Fem., } 15 \text { anos) } \\
\text { “... então, eu fico muito mal assim... em } \\
\text { relação ao meu corpo, mesmo. Porque } \\
\text { eu sempre fui uma pessoa que tive } \\
\text { dificuldade para emagrecer. Quando } \\
\text { incho... eu fico... nossa! E aí eu... ah... } \\
\text { não sei muito que eu faço, porque na } \\
\text { verdade tenho que fazer repouso, não } \\
\text { posso fazer exercício.”(Fem.,15 anos ) }\end{array}$ \\
\hline & Expectativa & $\begin{array}{l}\text { "Para mim é um pouco complicado } \\
\text { porque às vezes eu engordo... } \\
\text { emagreço... e também eu tenho } 15 \\
\text { anos, mas os meninos da minha } \\
\text { idade... com } 15 \text { anos é um pouco alto... } \\
\text { Mas como eu faço tratamento os } \\
\text { remédios às vezes desgastam o osso... } \\
\text { e isso impede de eu crescer... muitas } \\
\text { vezes a pessoa pensa que eu tenho } 11\end{array}$ \\
\hline
\end{tabular}




\begin{tabular}{|c|c|c|}
\hline & & $\begin{array}{l}\text { anos... por causa dos remédios." } \\
\text { (Masc., } 15 \text { anos) }\end{array}$ \\
\hline \multirow[t]{2}{*}{ Autoestima } & Segurança & $\begin{array}{l}\text { “Então assim... eu faço exercício físico, } \\
\text { eu estou começando a cuidar do meu } \\
\text { corpo, mas é mais por mim. Não mais } \\
\text { pelo que as pessoas vêem. Porque eu } \\
\text { não sou muito assim de ligar para a } \\
\text { opinião dos outros. (Fem., } 15 \text { anos) } \\
\text { "E nunca ninguém também veio e me } \\
\text { chamou de alguma coisa, gorda, ou } \\
\text { alguma coisa do tipo, então eu me } \\
\text { cuido para mim, e não para os outros, } \\
\text { porque eu quero causar uma impressão } \\
\text { para mim mesma e não para os outros” } \\
\text { (Fem., } 15 \text { anos) }\end{array}$ \\
\hline & Rejeição & $\begin{array}{l}\text { "As pessoas te vêem diferente"(Fem. } \\
\text {,15 anos) } \\
\text { "Você não quer ligar para o que os } \\
\text { outros dizem só que não quer ser } \\
\text { rejeitado..." (Fem.,15 anos ) }\end{array}$ \\
\hline
\end{tabular}

(continuação da tabela 14)

Quando às perguntas "O que faz você sentir melhor? O que te alegra?" foi proposta aos adolescentes, estes foram muito férteis em respostas, diálogos e comentários, possibilitando a partir as suas respostas definir três categorias de análise: lazer, relacionamentos e necessidades básicas (Tabela 15). 
$\mathrm{Na}$ categoria: lazer, evidenciou-se tudo que ser refere à música. Ouvir simplesmente, variando as preferências quanto ao gênero musical. Tocar instrumentos e assistir shows ao vivo ou em canais da internet.

“... eu escuto música... rock, eu gosto muito de rock... e eletrônica. (Fem.15 anos)"

A prática esportiva em jogos coletivos com os amigos e ao ar livre foi significativo. Aparece como opção de lazer e relaxamento, o uso de mídias. Eles participam de jogos virtuais, e gostam de assistir séries da TV. Os exemplos de discursos a seguir, demonstram estes itens.

"ah... gosto de jogar bola, jogar vídeo game" (Masc., 16 anos) e “... gosto de jogar bola, jogar vídeo game, gosto também de conversar com o meu primo que mora ao lado da minha casa... vou lá, converso com ele..." (Masc., 15 anos)

Os participantes citaram os relacionamentos como forma conforto em momentos difíceis. A família, o namorado(a), os amigos e outras pessoas próximas desempenham este papel.

Observamos que embora seja esperado que os adolescentes se afastem um pouco dos pais e procurem participar de grupos cuja maneira de pensar, agir e comportar-se é parecida com a sua, também encontram em outros adultos modelos a seguir, e pessoas com quem contar (Tabela 15). O depoimento a seguir ilustra este item:

“... Eu converso com a minha tia que ela é casada com o irmão da minha mãe e ela me ajuda bastante. (Fem., 15 anos)

Necessidades básicas são muito valorizadas na adolescência, o prazer de comer é uma fonte de alegria e alívio. E, como os demais adolescentes, apreciam longos períodos de sono.

“... o que me deixa feliz assim... É comer também, né, eu gosto de comer...” (Masc., 15 anos) 
Tabela 15: Análise qualitativa relativa às respostas da pergunta "O que faz você sentir melhor? O que te alegra?"

\begin{tabular}{|c|c|c|}
\hline Categorias & Itens & Exemplos de Discurso \\
\hline \multirow{3}{*}{ Lazer } & Música & "Eu ouço música" (quase todos) \\
\hline & Mídias & $\begin{array}{l}\text { "É que para mim é o que mais tira o stress, } \\
\text { por exemplo... estou estressado com } \\
\text { alguma coisa... pego o celular, começo a } \\
\text { jogar, passa... "(Masc., } 14 \text { anos) }\end{array}$ \\
\hline & Esporte & $\begin{array}{l}\text { "Eu gosto de ficar jogando vôlei com as } \\
\text { minhas amigas... (Fem., } 12 \text { anos) }\end{array}$ \\
\hline \multirow[t]{3}{*}{ Relacionamentos } & Amigos & $\begin{array}{l}\text { "Eu gosto muito de conversar com quem } \\
\text { me sinto segura "(Fem., 15anos) } \\
\text { "eu tenho uma prima... e uma pessoa que } \\
\text { eu gosto bastante de me abrir" (Fem.,15 } \\
\text { anos) }\end{array}$ \\
\hline & Família & $\begin{array}{l}\text { "E fico feliz quando meus pais me ajudam, } \\
\text { eles dão conselhos, sentam comigo, } \\
\text { conversam... assim... me apoiando... me } \\
\text { deixa feliz, me deixa contente, ver que eu } \\
\text { tenho o apoio de alguém...(Fem.,15anos) }\end{array}$ \\
\hline & Parceiro & $\begin{array}{l}\text { "Ah, dormir... assistir série... sair com a } \\
\text { minha mãe, com o meu namorado... saber } \\
\text { que eu tenho eles, que eu posso contar... } \\
\text { que me aceitam do jeito que eu sou, que } \\
\text { gostam de mim...(Fem.,14 anos)" }\end{array}$ \\
\hline
\end{tabular}




\begin{tabular}{l|l|l}
\hline $\begin{array}{l}\text { Necessidades } \\
\text { básicas }\end{array}$ & Comer & $\begin{array}{l}\text { "Eu como um pote de sorvete" (Masc. 16 } \\
\text { anos) }\end{array}$ \\
\cline { 2 - 3 } & Dormir & $\begin{array}{l}\text { "Eu gosto de comer, bastante, dormir" } \\
\text { (Fem., 15 anos) }\end{array}$ \\
\hline
\end{tabular}

(Continuação da tabela 15)

Dos discursos referentes às respostas relativas à pergunta: Quais são seus projetos para o futuro? Emergiram duas categorias que se relacionam com o futuro de maneiras bem distintas, planos reais e pensamento mágico. Os respondentes são otimistas e têm algum tipo de projeto. Observamos projetos que remetem as categorias observadas nas perguntas anteriores. Planos reais de trabalho e formação educacional, direcionados àquelas fontes de limitação e também de prazer (Tabela 16).

Eles têm planos profissionais relacionados a faculdade de gastronomia, e nutrição, e já revelaram desconforto com a privações alimentares e prazer de comer . Imaginam-se como jogador ou treinador de futebol profissional, mesmo os que têm dificuldades motoras.

Os adolescentes mais jovens têm sonhos mais ambiciosos, expressados como pensamento mágico. Enquanto que os adolescentes tardios têm planos mais concretos e factíveis, envolvendo ensino superior e projetos de trabalho. Desenham um caminho mais realista, porém não menos carregado de expectativas. O foco de projeto futuro remete às profissões ligadas à saúde, como exemplificam estas afirmações:

“... como todo menino, primeiramente, queria ser jogador, né, mas... como é difícil... se eu fosse fazer uma faculdade eu faria de gastronomia" (Masc., 15 anos)

“Eu penso se eu conseguir passar nas provas da ETEC no final do ano... eu tentei ano passado, não consegui passar, vou tentar esse ano de novo... E sei 
lá... eu sempre estou pensando aonde que eu vou estar... em 5 anos... ou com 10 anos... "(Fem., 15 anos).

“Eu quero cursar faculdade, quero fazer curso também, de artes assim, de medicina, para trabalhar assim em hospital também... ou então ser farmacêutico..." (Masc., 15 anos)

Tabela 16: Análise qualitativa relativa às respostas da pergunta "Quais são seus projetos para o futuro?"

\begin{tabular}{|c|c|c|}
\hline Categorias & Itens & Exemplos de Discurso \\
\hline & $\begin{array}{l}\text { Formação } \\
\text { educacional }\end{array}$ & $\begin{array}{l}\text { "Eu me preocupo muito com estudos... a } \\
\text { minha faculdade... eu quero... eu tenho } \\
\text { duas opções de faculdade, faculdade de } \\
\text { gastronomia e nutrição." (Fem., } 15 \text { anos) }\end{array}$ \\
\hline $\begin{array}{l}\text { Planos } \\
\text { Reais }\end{array}$ & Trabalho & $\begin{array}{l}\text { "Estou meio indeciso, civil ou elétrica... } \\
\text { porque meu pai trabalha com essas } \\
\text { coisas e elétrica é... tipo... ele é eletricista, } \\
\text { aí eu fiz um curso e gostei... é, tenho... o } \\
\text { modelo é meu pai, estou indeciso ainda..." } \\
\text { (Masc., } 16 \text { anos) }\end{array}$ \\
\hline $\begin{array}{l}\text { Pensamento } \\
\text { Mágico }\end{array}$ & Sonhos & $\begin{array}{l}\text { “... eu gosto de cantar, então... gostaria de } \\
\text { ser aquela cantora de... aquela coisa de... } \\
\text { criança, que você fala - ah, quero ser } \\
\text { famosa, quero ser... -. Mas... não que seja } \\
\text { impossível, porque acho que nada é } \\
\text { impossível...” (Fem., } 15 \text { anos). } \\
\text { “... eu quero ser 'youtuber'... eu fiz } 700 \\
\text { seguidores no Youtube... agora estou sem }\end{array}$ \\
\hline
\end{tabular}




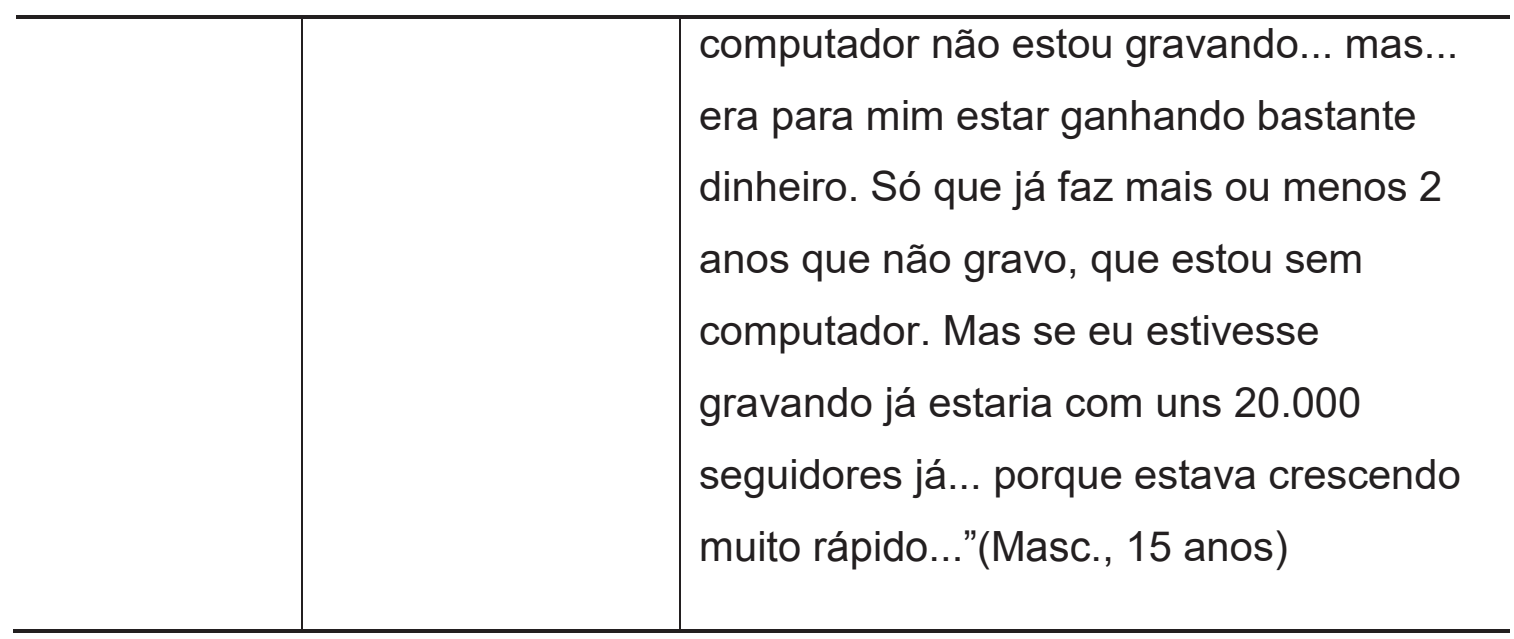

(Continuação da tabela 16)

No fim de cada grupo focal foi colocada a pergunta: Que conselho você daria ao profissional de saúde que o atende?

Como a pergunta ocorreu no final das sessões, os adolescentes estavam mais à vontade e comunicativos. Três categorias de análise para esta pergunta se apresentaram: comunicação, empatia e promoção de autonomia (Tabela 17).

$\mathrm{Na}$ categoria comunicação, eles se referiram às consultas de seguimento como algo repetitivo. Sendo um hospital a escola, eles reclamaram de médicos sempre diferentes que repetem as mesmas perguntas e as mesmas orientações. E sofrem com a morosidade do atendimento. Um dos participantes se expressou desta maneira:

“Por exemplo,.. para ser mais rápido o atendimento.... a maioria vão ter que imprimir os exames... ficaria bem mais rápido o atendimento, e... tem vez que eu demoro 2 horas aqui... aí demora bastante..."(Masc., 15 anos)

E na categoria empatia, os participantes foram generosos em exemplos, elogiando e criticando as relações com os profissionais, dando exemplo de consultas onde havia distanciamento e outros onde houve sintonia. Elogiaram os profissionais que os compreendem nas dificuldades com a sintomatologia 
diária e com a tolerância ao tratamento, como afirmou uma adolescente no grupo focal:

“... Tipo, eu não tenho o que reclamar a minha médica é maravilhosa, ela sempre deixa o lado profissional um pouco de lado e tenta me entender mais..."

(Fem., 15 anos)

Embora os adolescentes mais jovens tenham sido mais lacônicos nas suas respostas e mais tímidos na interação do grupo focal, alguns deles declararam que esperam ser recebidos com mais alegria. A adolescente disse:

$$
\text { “É... ser mais simpático... e não esperar tanto." (Fem.,13 anos) }
$$

"ah, eu acho que quando eles atendem a gente poderiam sorrir mais, ser mais alegres..." (Fem.,12 anos)

A promoção de saúde, prevenção de risco e promoção de autonomia estão entre os pilares da Medicina de Adolescência, baseadas em confidencialidade e privacidade. Os adolescentes, sujeitos desta pesquisa, são pacientes atendidos por pediatras especialistas. Nas consultas realizadas no Ambulatório de Especialidades Pediátricas da FCMSCSP não há oportunidade atendimento do adolescente sem a presença da mãe, no entanto, eles manifestaram o desejo de receber orientações diretas. A consulta direcionada à mãe impede que eles sejam mais participativos. Favorecer a confiança e independência é desejo dos adolescentes. Uma das adolescentes queixou-se:

“... quando tomava remédio eles falavam com minha mãe, não falavam comigo... tipo instruções, não falava para mim... seria legal saber o que eu vou fazer, o que eu vou tomar. (Fem., 15 anos)" 
Tabela 17: Análise qualitativa relativa às respostas da pergunta "Que conselho você daria ao profissional de saúde que o atende?"

\begin{tabular}{l|l|l}
\hline Categorias & Itens & Exemplos de Discurso \\
\hline
\end{tabular}

\begin{tabular}{|c|c|c|}
\hline \multirow[t]{3}{*}{ Comunicação } & Repetição & $\begin{array}{l}\text { "É tipo assim... é sempre a mesma } \\
\text { coisa... Chega aqui, uma moça chama a } \\
\text { gente, ela explica tudo sobre a doença, o } \\
\text { que aconteceu nesses últimos } 3 \text { meses... } \\
\text { que eu venho de } 3 \text { em } 3 \text { meses... Se eu } \\
\text { não pioro... porque eu moro em Santos, } \\
\text { entendeu?, e aí eles falam o que tem que } \\
\text { fazer e o que não tem que fazer, } \\
\text { entendeu?” (Fem.,15 anos) } \\
\text { “... é muito repetitivo...” (Fem. } 14 \text { anos) }\end{array}$ \\
\hline & Compreensão & $\begin{array}{l}\text { "Eu gosto do atendimento daqui, porque } \\
\text { tipo se você tem uma dúvida eles tiram } \\
\text { nossas dúvidas... conversa com a gente } \\
\text { bastante... é... acho que está tudo bem... } \\
\text { tranquilo..." (Fem., } 15 \text { anos) }\end{array}$ \\
\hline & Distanciamento & $\begin{array}{l}\text { "Eu queria... sei lá... pelo menos eu, } \\
\text { queria que eles entendessem um pouco. } \\
\text { Assim... tentassem entender mais... } \\
\text { isso... mas... sei lá... acho que alguns } \\
\text { médicos com os que eu já me tratei... } \\
\text { eles ficavam mais naquela zona do } \\
\text { profissional do que você tentar se } \\
\text { aprofundar e. tentar entender...” (Fem., } \\
15 \text { anos) } \\
\text { “... por que aquilo está acontecendo. }\end{array}$ \\
\hline
\end{tabular}




\begin{tabular}{|c|c|c|}
\hline \multirow{3}{*}{ Empatia } & & $\begin{array}{l}\text { Então, eles sempre pensam - ah, está } \\
\text { dando alguma coisa errada, então é } \\
\text { alimento... -, mas eles nunca pensam no } \\
\text { nosso psicológico..." (Fem., } 15 \text { anos) }\end{array}$ \\
\hline & Sintonia & $\begin{array}{l}\text { "Eu me sinto bem por ser atendida aqui, } \\
\text { os médicos sempre falam de igual para } \\
\text { igual, eles dão conselhos, eles não } \\
\text { chegam te dando bronca, eles falam - } \\
\text { ah... isso aqui é melhor para você... -, - o } \\
\text { jeito que está fazendo não está certo... } \\
\text { não está dando certo, tem que mudar -. } \\
\text { Isso eu acho legal, não chegam tipo 'eu } \\
\text { sou mais que você, porque você é } \\
\text { paciente e eu sou médico..." } \\
\text { (Fem.,14anos ) }\end{array}$ \\
\hline & Alegria & $\begin{array}{l}\text { "Ah, eu acho que quando eles atendem a } \\
\text { gente poderiam sorrir mais, ser mais } \\
\text { alegres..."(Fem.,12 anos) }\end{array}$ \\
\hline \multirow[b]{2}{*}{$\begin{array}{l}\text { Promoção } \\
\text { de } \\
\text { Autonomia }\end{array}$} & Independência & $\begin{array}{l}\text { "Ah, acho que eles deveriam tratar a } \\
\text { gente mesmo como adolescente e não } \\
\text { como um doente, que você não pode } \\
\text { fazer quase nada... e também ser um } \\
\text { pouco mais pacientes, porque muitas } \\
\text { vezes a gente não sabe se eles querem } \\
\text { que a gente responda ou os nossos } \\
\text { pais... então. (Fem.,16 anos) }\end{array}$ \\
\hline & Confiança & $\begin{array}{l}\text { "Ah, tem que falar para eles acreditar } \\
\text { mais na gente." (Masc., } 15 \text { anos) } \\
\text { "Acreditar mais na gente, que quando a }\end{array}$ \\
\hline
\end{tabular}




\begin{tabular}{l|l|l}
\hline & $\begin{array}{l}\text { gente fala que está tomando os remédios } \\
\text { eles não acreditam." (Masc., 15 anos) }\end{array}$ \\
\hline
\end{tabular}

(Continuação da tabela 17). 


\section{Discussão}

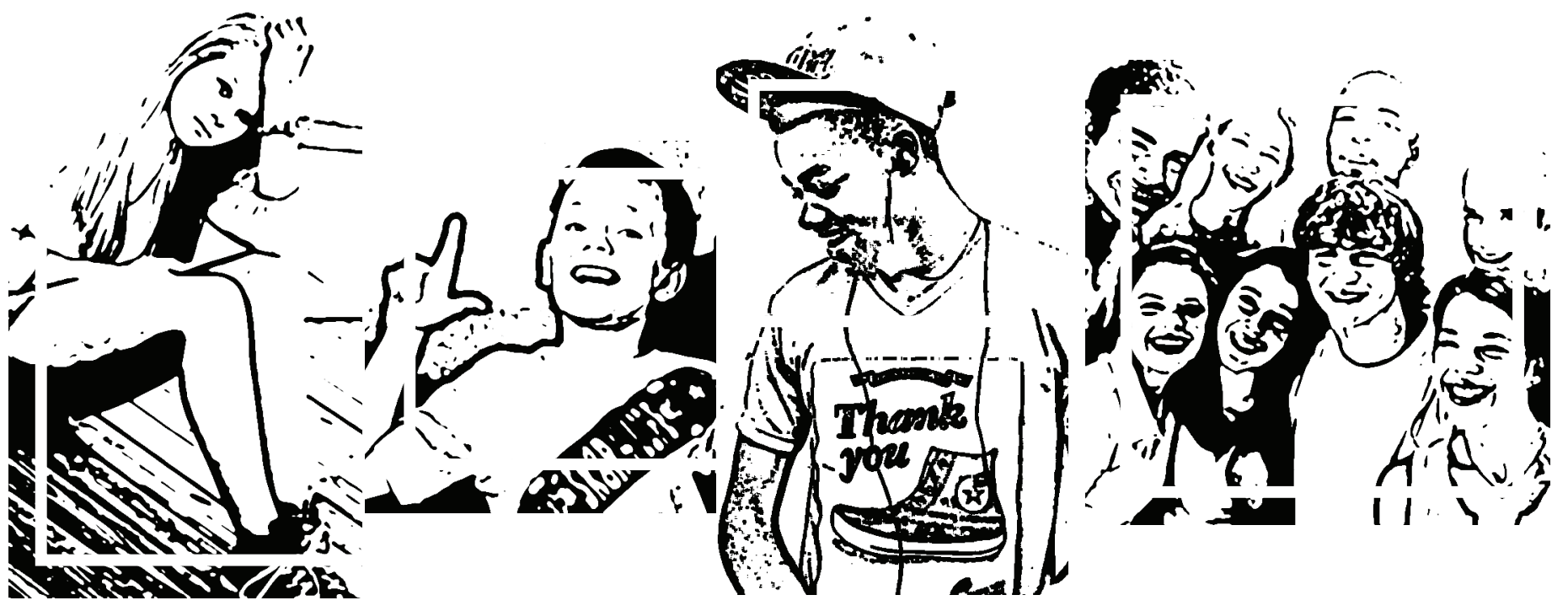




\section{DISCUSSÃO}

O presente estudo demonstra a partir de dados quantitativos que a percepção da qualidade de vida por autoavaliação não variou em relação ao sexo, grupo etário, ano letivo perdido e grau de escolaridade dos pais. Observou-se diferença por meio do WHOQOL-BREF que adolescentes mais jovens têm escores mais elevados no domínio relações sociais. Observamos também menores escores de resiliência estão associados ao atraso escolar.

Os dados qualitativos permitem afirmar que os adolescentes com doença crônica, percebem suas limitações e experimentam o desenvolvimento pessoal a partir da sua vivência do processo de adoecimento e tratamento. A experiência do tratamento gera sentimentos ambíguos. Ao mesmo tempo em que traz revolta pelo desconforto e dor, favorece o desenvolvimento de resiliência. A rede de suporte representada pela família e amigos é valorizada pelos adolescentes, porém identificou-se ambivalência de sentimentos em relação ao cuidado de ambos. No grupo estudado, destacam-se sentimentos de constrangimento referentes à imagem corporal e seus efeitos sobre a autoestima. Os sujeitos desta pesquisa apreciam as oportunidades de lazer como esporte, mídias e atividades relacionadas à música. Reconhecem os relacionamentos sociais e têm vínculos e modelos entre amigos, família e parceiros. Atividades básicas como comer e dormir foram consideradas fatores de promoção de bem-estar.

Os adolescentes com doenças crônicas que participaram deste estudo têm clareza dos seus projetos de vida. Desde sonhos mágicos até planos reais, alguns relativos às experiências que envolvem a doença e tratamento. As profissões desejadas remetem às questões ligadas à saúde ou mesmo as limitações como privação alimentar e vigor esportivo. Eles manifestam desejo de participação ativa no seu tratamento, o que é relevante para serviços de saúde de transição direcionados a esta faixa etária. E, finalmente, em relação aos cuidados de saúde para este grupo, foi sugerido que as equipes de saúde sejam mais empáticas, favoreçam a promoção de autonomia, melhorem a comunicação e atuem com mais alegria. 
Esta síntese dos resultados do presente estudo norteará a nossa discussão.

\section{Qualidade de Vida, Doença Crônica e Adolescência}

Nos últimos anos, foram publicados muitos estudos que envolvem doenças crônicas e qualidade de vida (QV). Eles refletem uma ampliação do foco destas pesquisas que incluem outros aspectos além daqueles relacionados apenas à doença, terapêuticas ou prognóstico, mas incluindo dimensões psicológicas e sociais do indivíduo com condições crônicas de saúde. A maioria dos estudos enfocam indivíduos adultos acometidos de enfermidades crônicas e capazes de produzir sequelas.(1,49-53) Nas últimas décadas novos estudos têm sido publicados envolvendo crianças e adolescentes. Boa parte destas pesquisas são de metodologia quantitativa utilizando-se de instrumentos validados. Alguns são específicos por doenças, outros por faixa etária e adaptados por doenças. $\left({ }^{15,54-72)} \mathrm{E}\right.$, principalmente, incluem pais e cuidadores como respondentes. Justifica-se esta abordagem pelas singularidades das faixas etárias estudadas e pelas implicações da condição crônica que atingem o núcleo familiar.

Contudo, acreditamos que a abordagem global diretamente dirigida ao paciente adolescente, deva ser precoce durante todo o seguimento terapêutico. Isto é válido tanto para os adolescentes iniciais quanto para os adolescentes de qualquer idade com diagnóstico recente da condição crônica. É sempre vantajoso e produtivo colocá-los no local central, pois são eles os pacientes de fato e quanto mais apropriados de todo processo, mais seguros e aderentes se tornam.

O estudo realizado em 2016 por Teresa Santos apresentou ampla investigação a respeito da qualidade de vida, percepção de saúde, resiliência, auto-regulação e suporte social nos adolescentes portugueses com doença crônica. A autora conduziu o estudo em três fases. A primeira fase usou dados transversais do estudo nacional Health Behaviour in School-aged Children (2010) em 5050 adolescentes $(52.3 \%$ do sexo feminino, $14 \pm 1.85$ anos foi a média de idade). Foram feitas comparações entre adolescentes com e sem doença crônica, e, dentro deste segundo grupo, foram comparados os 
adolescentes que se sentiam afetados e os que não se sentiam afetados na participação escolar. Os adolescentes com doenças crônicas apresentaram maiores riscos nas variáveis individuais-psicológicas (percepção de saúde, satisfação com a vida e bem-estar psicológico) e sócio-contextuais (satisfação com a família, auto percepção de competência escolar, pressão com os trabalhos escolares e comportamentos de risco), comparados com adolescentes saudáveis. Os adolescentes com doenças crônicas mais vulneráveis eram os mais velhos, as do sexo feminino, com situação socioeconômica mais baixa e os que se sentiam afetados na participação escolar. ${ }^{(73)}$

Deste mesmo estudo, em outra fase, esta pesquisa usou dados transversais recolhidos em contexto clínico em 135 adolescentes $(51.9 \%$ rapazes, $14 \pm 1.5$ anos foi a média de idade), com diabetes mellitus, doenças alérgicas ou neurológicas. A QVRS, saúde psicossomática, resiliência, auto regulação e suporte social foram avaliados por o tipo de doença, e entre adolescentes que se sentiam afetados ou não na participação escolar. As adolescentes do sexo feminino e aqueles afetados na participação escolar/social apresentaram piores resultados na QVRS e funcionamento psicossocial; não se verificaram diferenças de acordo com o tipo de doença. $E$ finalmente, foi feita uma revisão sistemática sobre associações entre doenças crônicas, QVRS e fatores psicossociais. A literatura demonstrou uma associação entre doenças crônicas na adolescência e resultados negativos na QVRS e funcionamento psicossocial, bem como escassez de estudos na adolescência como grupo etário independente. ${ }^{(73)}$

Em nosso estudo, a respeito destes aspectos, encontramos menor perda de ano letivo nos adolescentes de maiores escores de resiliência. $E$ adolescentes mais velhos tinham menores escores de qualidade de vida no domínio social avaliados apor meio de WHOQOL-BREF.(12) No entanto, a percepção da qualidade de vida por autoavaliação não variou em relação ao sexo, grupo etário, ano letivo perdido e grau de escolaridade dos pais.

Rivera e colaboradores em 2015, compararam através de questionários com crianças e cuidadores, a QV de crianças com e sem 
condições crônicas de saúde em geral, demonstrando menores escores de bem-estar físico e psicológico naquelas crianças com doenças crônicas. ${ }^{(57)}$

Sawyer publicou revisão em 2007, sobre os desafios dos adolescentes que convivem com doenças crônicas, e enfatizou que os adolescentes estão em melhor posição para comentar sobre suas experiências com sintomas, relações entre pares, e preocupações com o futuro, como também vimos nos resultados do presente estudo. As alterações habituais que ocorrem durante a infância e adolescência mudam as percepções acerca da qualidade de vida, devendo, receber a devida importância. ${ }^{(74)}$

Em nossa pesquisa, priorizou-se a participação ativa dos adolescentes na produção de dados. Foram eles os respondentes individualmente dos instrumentos de pesquisa da fase quantitativa, assim como na participação dos grupos focais cujas sessões foram realizadas sem a presença dos pais. Na prática clínica, do Ambulatório de Especialidades Pediátricas do Departamento de Pediatria da Faculdade de Ciências Médicas da Santa Casa de São Paulo (FCMSCSP), percebemos que sem o engajamento deles, pouco se consegue na evolução seja do tratamento, adesão ou conquista de autonomia aliada à percepção da doença crônica.

De acordo com o estudo Health Behaviour In School-Aged Children (HBSC) ${ }^{(75)}$ de 2013/2014, que consiste num estudo colaborativo da OMS em vários países europeus sobre do comportamento da saúde em crianças em idade escolar, a percepção de saúde auto-avaliada é um indicador subjetivo de saúde geral. Na adolescência, refere-se não apenas à presença ou ausência de doença ou incapacidade crônica, mas também a uma compreensão mais geral de si e é influenciada por uma ampla gama de indicadores de saúde, incluindo fatores contextuais sociais, socioambientais e comportamentais e, mais amplos, como a família, os pares, a escola e o status cultural, como foi observado nos resultados da fase qualitativa do presente estudo.

A despeito da natureza subjetiva, de modo geral, a autoavaliação de saúde é comumente utilizada em inquéritos populacionais, sendo 
considerada um bom preditor de mortalidade e futura utilização dos serviços de saúde. No Brasil, os dados da Pesquisa Nacional de Saúde do Escolar (PeNSE) ${ }^{(76)}$ publicados em 2016 revelam que, de modo geral, a maioria dos estudantes brasileiros de $9^{\circ}$ ano do ensino fundamental tem uma avaliação positiva da própria saúde: $73,0 \%$ deles classificaram seu estado de saúde como muito bom ou bom, 19,9\%, como regular e $7,1 \%$ consideraram ruim ou muito ruim. Foram encontradas diferenças entre gênero, corroborando achados da OMS: ${ }^{(75)}$ as alunas fizeram avaliações mais negativas de seu estado de saúde (68,6\% muito bom ou bom; $23,7 \%$ regular; $7,7 \%$ ruim ou muito ruim) em comparação aos escolares do sexo masculino $(77,7 \%$ muito bom ou bom; $15,8 \%$ regular; $6,5 \%$ ruim ou muito ruim).

Foi encontrada no presente estudo diferença estatisticamente significativa apenas no Domínio Relações Sociais por meio do WHOQOLBREF. ${ }^{(12)}$ Os adolescentes menores de 15 anos têm escores mais elevados. As perguntas que se referem ao Domínio Relações Sociais deste instrumento, destacam o apoio e a satisfação do respondente com as relações com suas famílias, parentes, amigos e parceiros sexuais.

Em nossa amostra, a idade dos adolescentes variou de 12 a 18 anos, já que 12 dos $31(38,7 \%)$ não responderam este item, sendo que destes, dois $(16,6 \%)$ eram maiores de 15 anos. Acreditamos que isto ocorreu possivelmente porque os participantes deste estudo desta faixa etária não haviam experimentado ainda a sexarca. Segundo dados de inquéritos epidemiológicos, 15 anos parece ser uma idade que marca o início da atividade sexual. Dados obtidos de pesquisas de comportamento sexual conduzidas pelo Centers of Disease Control (CDC) de 2011, revelam que 43,8\% dos estudantes no $10^{\circ}$ grau e até $63,1 \%$ no $12^{\circ}$ grau já tinham tido a primeira experiência sexual. ${ }^{(77)}$ No Brasil, dados da Pesquisa Nacional de Demografia e Saúde da Criança e da Mulher (PNDS-2006) publicada em 2009, também apontam para uma prevalência de $33 \%$ de mulheres que já haviam tido relações sexuais até os 15 anos. ${ }^{(78)}$

Tanto do ponto de vista somático como psicológico e social, nesta fase inicial e início da adolescência média, os adolescentes tendem a estar mais 
confortáveis em situações sociais familiares, onde a condição crônica e suas limitações são conhecidas e aceitas. Contam com a proteção dos pais, cuidadores e amigos mais íntimos. A tendência social grupal pode ainda não ser dominante, assim há menos situações onde a doença crônica os restringiria em ambientes sociais como festas ou trabalho ou em relações afetivas como namoro. A socialização além da família, presente nesta passagem para o mundo adulto, requer recursos emocionais e, sobretudo, experiência. Aparentemente, ter menos idade os expõe menos ao contato social amplo, como que simplificando as relações sociais onde o adolescente não precisa conquistar, competir e os mantém entre aqueles que lhe proporcionam aconchego e tranquilidade.

Referente à escolaridade, os participantes com idades até 15 anos cursavam o ensino fundamental, $57,8 \%$ dos adolescentes quando as exigências acadêmicas costumam ser inferiores àquelas do ensino médio. No primeiro ano do ensino médio encontramos $42,1 \%$ deste grupo, e no grupo dos maiores de 15 anos, $77,3 \%$ dos respondentes frequentavam o ensino médio. Este seria outro fator que explicaria este resultado, pois Brasil, em escolas públicas, há progressão automática no ensino fundamental de nove anos. Segundo a Resolução SE 53, de 2-10-2014 da Secretaria de Educação do Estado de São Paulo, a avaliação para progressão ocorre após três ciclos: do $1^{a}$ ao $3^{\circ}$ ano, do $4^{\circ}$ ao $6^{\circ}$ ano e do $7^{\circ}$ ao $9^{\circ}$ ano. ${ }^{(79)}$ Existe, portanto, aumento das exigências escolares e demanda por resultados melhores conforme avançam na escolaridade e paralelamente na faixa etária.

Os adolescentes no Brasil com idade superior a 15 anos aproximam-se da adolescência tardia, fase em que se defrontam com novos desafios como engajar-se no primeiro emprego ou ingresso na universidade através do Exame Nacional do Ensino Médio (ENEM). Enfrentam, neste percurso, situações de decisões significativas dentro do meio social. Estão mais afastados do núcleo familiar, podem ter relações afetivas mais compromissadas, necessitam de mais foco e dedicação para disputar as vagas de trabalho e/ou conseguir iniciar o curso superior, e, em alguns casos, tornam-se necessários como fonte de trabalho e renda para suas famílias. As relações sociais tornam-se mais 
complexas, justificando assim piores resultados no Domínio Relações Sociais nas faixas etárias superiores.

Observamos em nossa pesquisa aspectos da escolaridade que menores escores de resiliência estão associados ao atraso escolar. Sobre resiliência, a pesquisa clássica de Emmy Werner que conduziu um estudo prospectivo longitudinal de uma coorte multirracial de 698 crianças nascidas em 1955 na ilha Kauai, foi uma das maiores investigações interdisciplinares da resiliência em crianças vulneráveis publicado em 1989. Os principais objetivos do estudo longitudinal de Kauai foram: documentar e avaliar, desde o período gestacional até a prole atingir a idade adulta, as consequências em longo prazo de complicações neonatais e condições adversas durante toda a formação desta amostra no desenvolvimento físico, cognitivo e psicossocial dos indivíduos. Durante todo o estudo, foram encontradas tanto situações de vulnerabilidade (susceptibilidade a resultados negativos em condições de alto risco) quanto a resiliência (adaptação bem-sucedida após exposição a eventos de vida estressantes). Apenas um terço dos bebês poderia ser considerado "de risco" por exposição a estresse perinatal, a pobreza, ao baixo nível de escolaridade materna, ao ambiente familiar desfavorável pela existência de alcoolismo ou doença mental dos pais, abandono ou divórcio. Duas em cada três dessas crianças submetidas a quatro ou mais fatores de risco cumulativos antes dos dois anos de idade, desenvolveram sérios problemas de aprendizado ou de comportamento até os dez anos de idade, ou tiveram registros de delinquência, problemas de saúde mental ou gestações na adolescência antes de 18 anos. No entanto, um em cada três deles cerca de $10 \%$ da coorte total (72 indivíduos, 30 do sexo masculino 42 do sexo feminino) tornaram-se adultos jovens competentes, confiantes e atenciosos. Os fatores protetores que foram determinantes para a resiliência do estudo se apresentaram como um atributo do indivíduo, tais como o nível de sociabilidade, pelo menos inteligência média, competência em habilidades de comunicação (linguagem, leitura) e capacidade autocontrole. Laços afetivos dentro da família capazes de fornecer apoio emocional em situações adversas. E, finalmente, fator de proteção foi reconhecido em sistemas de apoio externo, seja na escola, no trabalho ou na 
igreja, que recompensem e influenciem as competências e a determinação do indivíduo e proporcionem uma rede de apoio e valores culturais, sociais e éticos. ${ }^{(80,81)}$

A resiliência se expressa na forma como os adolescentes com condições crônicas e suas famílias se ajustam de forma emocional e comportamental às perturbações a que são expostos e assim possam alcançar bons resultados de saúde e ter vidas felizes, produtivas e satisfatórias. Porém, as respostas de adaptação são muito variáveis e não homogêneas, dependendo de fatores individuais e do contexto sociocultural de cada adolescente, e também do tipo de condição crônica e suas limitações.

Segundo o modelo ecológico de Bronfenbrenner, no desenvolvimento da adolescência, ocorre da relação mútua entre os sistemas e por sua vez entre os vários componentes de um sistema, assim como há impacto resultante das mudanças que ocorrem no decorrer do tempo. $\mathrm{Na}$ adolescência, a família é considerada como sendo o principal microssistema, uma vez que é nesta que ocorrem as interações e experiências mais diretas e significativas para o indivíduo. O grupo de pares e a escola representam microssistemas de destaque para os adolescentes. Assim, torna-se necessário considerar todo o sistema ecológico em que o adolescente vive e que contribuem para o desenvolvimento humano, que se relacionam e são dinâmicos, ou seja: a pessoa $(P)$, o processo $(P)$, o contexto $(C)$ e o tempo $(T)$, designando-se por Modelo PPCT, sendo que ao longo do seu desenvolvimento a pessoa $(P)$ vai envolvendo-se em processos $(P)$ de interações recíprocas com outros indivíduos, objetos ou ainda símbolos. Estas interações, porém, podem se diversificar conforme as características de cada indivíduo, bem como o momento ( $\mathrm{T}$ ) e os contextos (C) em que ocorrem. O trabalho dos pais, a rede de apoio social e a comunidade na qual a família do adolescente se insere podem interferir e afetar de forma positiva ou negativa o desenvolvimento do adolescente. $^{(82)(83)(84)(85)}$

Crump, Bethell e Champaloux, estudaram o efeito da doença crônica no desempenho acadêmico. Em 2013, Crump publicou um estudo retrospectivo de 22.730 crianças e jovens (entre o $2^{\circ}$ e $11^{\circ}$ grau) em San Jose, 
Califórnia, entre 2007 a 2010. Verificaram-se nesta amostra, 14,57\% estudantes com doenças crônicas. O desempenho escolar foi medido através testes padronizados de inglês e de avaliações de matemática. As condições crônicas de saúde foram associadas com baixo desempenho em ambas as avaliações, independentemente da etnia, ano escolar ou condição socioeconômica. Os piores desempenhos foram encontrados nos estudantes com transtornos do desenvolvimento neurológico e quadros convulsivos mas não naqueles com doenças cardiovasculares ou diabetes. ${ }^{(86)}$

Outra pesquisa conduzida nos Estados Unidos entre 2011 e 2012 por Bethell e colaboradores e publicada em 2014 a partir dos dados nacionais de saúde infantil, avaliou, entre outras características, o impacto da saúde no engajamento escolar em crianças e adolescentes de seis a 17 anos que haviam sofrido alguma adversidade durante a vida, entre elas: necessidades especiais de saúde, transtornos do desenvolvimento, condições crônicas de saúde como asma, obesidade, distúrbios de comportamento e transtorno de déficit de atenção e hiperatividade (TDAH) e o papel atenuante da resiliência. Aqueles com duas ou mais experiências adversas na infância foram 2,67 vezes mais propensas a repetir uma série na escola, em comparação com crianças sem nenhuma experiência. A resiliência atenuou 0 impacto destas adversidades no grau de atraso e engajamento escolar. Entre as crianças com necessidades especiais de cuidados de saúde que tiveram duas ou mais experiências adversas, aqueles que aprenderam e demostraram aspectos de resiliência, definido na pesquisa como estado de "permanecer calmo e sob controle quando confrontado com um desafio" foram 1,55 vezes mais propensos a participar na escola e apresentaram quase metade da probabilidade de repetir uma série na escola, em comparação com aqueles que não apresentam resiliência. ${ }^{(87)}$

Champaloux publicou em 2015 um estudo em adolescentes escolares que cresceram com doenças crônicas como câncer, cardiopatias, asma, diabetes e epilepsia; através de questionários e entrevista semiestruturada demonstrando que aqueles que relataram ter uma doença crônica têm maior probabilidade de estabelecer nível educacional mais baixo 
em comparação com jovens que não relataram a condição crônica. Eles têm mais absenteísmo, perda de ano letivo e sintomas depressivos. ${ }^{(88)}$

Os efeitos da condição crônica não são exclusivamente orgânicos. Ela afeta o desenvolvimento emocional e físico dos estudantes, o desempenho acadêmico, os relacionamentos entre colegas e as interações familiares.

\section{Percepcão da Doença e Desenvolvimento Pessoal}

O período da adolescência com suas transformações e a evolução da doença crônica, em alguma fase da vida, interferem uma sobre a outra. Este encontro inevitavelmente traz consequências, seja no processo de saúde-doença-tratamento, seja no processo dinâmico da adolescência de cada indivíduo.

Suris e colaboradores, em 2004 descreveram a repercussão relativa aos efeitos da doença crônica sobre o desenvolvimento e deste sobre a doença em crianças e adolescentes, sob aspectos biológicos, psicológicos e sociais. ${ }^{\left({ }^{89-91)} \mathrm{O}\right.}$ desenvolvimento biológico, psicológico e social é interrelacionado, um aspecto afetando o outro.

Da perspectiva biológica, observamos que o retardo do crescimento e da puberdade são comuns à maioria das doenças crônicas, embora mais frequentes nos casos em que a desnutrição e a inflamação crônica se impõem. Esse atraso pode ser transitório ou permanente, interferindo na estatura final e na aquisição de massa óssea. As demandas metabólicas do crescimento e alterações hormonais podem alterar os parâmetros de algumas doenças crônicas como diabetes. Sob o prisma psicológico, a doença pode mantê-los infantilizados e egocêntricos por mais tempo, identificados com o papel de doentes. Pode, além disso, prejudicar o desenvolvimento das funções cognitivas e amadurecimento da sexualidade. A vivência da adolescência pode piorar adesão e controle da doença devido a: capacidade reduzida de planejamento, rejeição de profissionais médicos como 
parte da separação de pais e comportamento exploratório com sensação de invulnerabilidade.

Socialmente, a doença pode acarretar menor desenvolvimento da independência, isolamento social, dificuldade de relacionamento com pares ou com parceiros afetivos, piores resultados acadêmicos e na capacidade de não depender de outros. Na adolescência são mais comuns os comportamentos de risco que prejudicam o tratamento da doença crônica como hábitos alimentares ruins, tabagismo, alcoolismo ou uso de substâncias psicoativas, e ainda, comportamento sexual desprotegido.

A percepção da doença tem caráter cognitivo, enquanto a compreensão dos sintomas e das limitações a que estes adolescentes estão sujeitos são da esfera do pensamento concreto presentes na infância e adolescência inicial. Assimilar as causas, quando possível, a duração, as consequências e o controle exigem abstração, habilidade que é adquirida conforme a adolescência progride. Igualmente, os fatores físicos e biomédicos diminuem sua importância como determinantes da QV auto percebida e os fatores psicossociais tornam-se relevantes conforme transcorre a adolescência.

Percebe-se nos resultados de nossa pesquisa, um dos aspectos descritos por Aberastury e Knobel: ${ }^{(31)}$ a ambivalência de sentimentos. O adolescente típico pode até pretender ter uma conduta mais definida em relação a doença ou ao tratamento, porém, a personalidade ainda é permeável, a instabilidade de sentimentos, ações e humor é a regra e não exceção. 0 adolescente lida com as demandas do processo de adoecer e ser submetido a tratamentos muitas vezes penosos com os recursos que dispõe. É o mundo adulto que não suporta as mudanças de comportamento, as oscilações e contradições. Em outras palavras, eles são o que conseguem ser, e não o que se pretende deles e, em fase evolutiva, a cada etapa, podem manifestar reações diferentes. ${ }^{(92)}$

A doença, bem como seu tratamento constituem situação de vulnerabilidade para o adolescente. Ficou demonstrado neste estudo que os adolescentes elaboram mecanismos de superação sem causar sequelas 
emocionais, na medida em que tanto a adolescência como a doença e tratamento se desenvolvem. Percebemos que os adolescentes mais velhos, já se apropriaram da condição crônica, encontrando caminhos para viver a adolescência mesmo doentes, aproximando-se o quanto podem dos seus pares e apresentam comportamentos mais maduros e sólidos do que costumamos ver nos adolescentes da mesma faixa etária.

“... Então acho que você tem que ter responsabilidade... e uma visão madura assim, porque... se você fizer alguma coisa errada... ou comer muito sal, no meu caso... você vai acabar se prejudicando. Então, acho que... tem que amadurecer antes, né, porque... do que certos adolescentes que não tem problema, para... partir dessa para melhor... (ri)" (Fem., 15 anos)

\section{Cuidado Parental e de Amigos}

Adolescentes deste estudo valorizam da rede de suporte representada pela família e amigos, e apresentam ambivalência de sentimentos em relação ao cuidado de ambos. Entendemos esta dualidade sob a perspectiva de Aberastury e Knobel. ${ }^{(31)} \mathrm{O}$ período da adolescência experimenta perdas, entre eles, o luto pelos pais da infância. É um momento que se perde o espaço da função e do comportamento de criança que eram aceitos pelos pais, sem ainda adquirir o papel de adulto. Ao olharem-se no espelho percebem que perderam aquele encanto infantil que lhes garantiam amor incondicional e a proteção dos pais. Mas não ganharam ainda o reconhecimento do mundo adulto, gerando insegurança. Perdem privilégios e ganham deveres esperados para o ambiente adulto, confundindo ambas as partes da relação. Uma das tarefas básicas do adolescente é separar-se dos pais. De novo, vemos aqui um cenário de ambiguidade. Por parte dos pais que negam o crescimento dos filhos e por parte dos filhos que se incomodam com a atitude de superproteção dos pais. O conflito familiar é comum. Os pais muitas vezes têm pouca compreensão ou orientação para lidar com essas questões e, na melhor das hipóteses, tendem a tornar-se excessivamente protetores e ansiosos. ${ }^{(92)}$ 
Os modelos educativos na família influenciam fortemente os comportamentos e a socialização, tendo um papel decisivo no desenvolvimento da criança. O Inventário de Estilos Parentais (IEP), desenvolvido e validado no Brasil e publicado em 2006, é um instrumento que avalia as estratégias e técnicas utilizadas pelos pais para educar os filhos por meio de sete práticas educativas, sendo cinco vinculadas ao desenvolvimento do comportamento antissocial, as disciplinas negativas: negligência, punição inconsistente, disciplina relaxada, monitoria negativa e abuso físico; e duas relacionadas ao desenvolvimento de comportamentos pró sociais, as disciplinas positivas: comportamento moral e monitoria positiva. Ele se expressa em escores a partir da do cálculo do índice de estilo parental é feito pela subtração da soma das disciplinas negativas e da soma das positivas.(93) Este instrumento se mostrou consoante com outros instrumentos como inventários de depressão, estresse e habilidades sociais e se correlacionou positivamente com o Inventário de Habilidades Sociais e negativamente com os Inventários de Depressão e de Stress, embora tenha sido feito num amostra pequena, apresenta uma possibilidade de relacionar o cuidado parental com condições de risco em crianças e adolescentes. ${ }^{(94)}$

O papel dos pais e cuidadores é ainda mais relevante perante uma situação de doença crônica, oscilando entre: necessidades de proteção da saúde, e, de autonomização e responsabilização. Estilos parentais restritivos, aqueles nos quais os pais e mães possuem altos níveis de controle, são impositivos sobre a conduta dos filhos, exercem níveis altos de exigência, tendem a enfatizar a obediência e valorizam menos o diálogo e a autonomia, foram identificados como obstáculos a uma boa adaptação dos jovens com doença crônica. Enquanto um estilo parental democrático, em que os pais exerceriam controle de modo racional e democrático, ao invés de dominador, reconhecendo a perspectiva de seus filhos e provendo orientação se apresenta como facilitador da adaptação à doença. ${ }^{(95)}$

Por estas razões, a adolescência é um período especialmente suscetível para aqueles com doença crônica. Alguns destes adolescentes são criados da infância a adolescência com tutela extrema, desconsiderando suas 
possibilidades de aquisição de maturidade, independência e autoestima, mesmo para doenças menos complexas, já resolvidas e sem limitações ou sequelas. Por outro lado, alguns adolescentes, independente da complexidade da sua situação de saúde, acomodam-se nesta zona de conforto, alimentandose emocionalmente desta condição, obtendo, eventualmente, ganhos secundários e desorganizando ainda mais a relação e o cuidado parental.

Wolman comparou adolescentes com e sem condições crônicas. Entre outros aspectos, o bem-estar emocional foi examinado em função da percepção da conexão familiar. Foram comparados 1683 alunos com diversas condições crônicas (sete a 12 anos) por meio da Pesquisa de Saúde do Adolescente, com 1658 alunos sem condições crônicas. Os adolescentes com condições crônicas tiveram escores emocionais mais baixos, revelaram-se preocupados com a prematuridade da morte, com o desempenho escolar e as perspectivas de trabalho futuro. Eles têm piores percepções da imagem corporal, preocupam-se com a própria incapacidade e com os relacionamentos entre colegas. Para adolescentes com e sem condições crônicas, maiores pontuações de bem-estar emocional foram significativamente relacionadas aos maiores níveis de conectividade familiar. Neste estudo, embora os adolescentes com condições crônicas percebessem menor conexão coma família, em ambos os grupos, a conexão familiar foi positivamente associada ao bem-estar emocional dos adolescentes. A conexão familiar foi definida pelas próprias percepções e perspectivas pessoais dos adolescentes. ${ }^{(96)}$

Isto reforça o que vemos na prática do seguimento dos adolescentes em geral e nos dados produzidos qualitativamente no presente estudo, dado o papel central da família como fator protetor ou de risco no desenvolvimento de crianças e adolescentes, em especial aqueles com necessidades especiais. Ao mesmo tempo em que trabalhamos na construção da autonomia e estimulamos autocuidado e independência, procuramos evitar $\mathrm{o}$ isolamento de pais e cuidadores. Parece que o equilíbrio entre ter apoio familiar sem superproteção dos pais e o sentimento de pertencimento nos grupos, aumenta a autoestima e é crucial para o bem-estar dos adolescentes. 
O primeiro grupo social é a família. O adolescente ainda não adquiriu o reconhecimento dos adultos para ser aceito entre eles, como que vivendo um período de moratória, assim eles tornam-se gregários e estabelecem novos vínculos sociais onde é o adulto que é excluído e podem, então, reconhecerem-se uns aos outros como pares. E, na busca de identidade, recorre ao comportamento defensivo, procura situar-se num grupo de outros adolescentes que lhe garanta alguma uniformidade, proporcionando autoestima e segurança. ${ }^{(31)}$ Em outras palavras, há o desejo de pertencer, de ser igual e não diferente. Assim, quanto mais incluído dentro do grupo, mesmo no papel de alguém que é cuidado pelos companheiros, melhor.

Sobre os amigos, um participante narrou:

"Até tem um amigo meu que lembra que às 5 horas é a hora de tomar o remédio e - e aí, já tomou o remédio?, se não tomou vai agora tomar -, sempre tem aquele amigo que fica no meu pé, que está desde que descobri essa doença, está estudando comigo até hoje."(Masc., 14 anos)

Contudo, embora pouco relatado em nosso estudo, na literatura encontramos estudos como o de Sentenac e colaboradores que utilizou dados de 55030 alunos com idades 11, 13 e 15 anos de 11 países que participaram da pesquisa entre 2005-2006 Health Behavior in School-aged Children através de questionários auto respondidos. Em todos os países estudados, os alunos que relataram condições crônicas de saúde apresentaram maior probabilidade de serem vítimas de bullying. As vítimas de bullying relataram percepção de saúde subjetivos mais negativos, independentemente do situação de controle da doença . E concluiu que, a educação inclusiva é importante para melhorar a qualidade da integração de estudantes com doenças crônicas. ${ }^{(97)}$

A valorização do cuidado parental ou dos amigos que emergiu como dado produzido nos grupos focais desta tese, vieram confirmar duas características definidas por Aberastury e Knobel. ${ }^{(31)}$ No entanto, com sentido de ambiguidade, embora seja esperado que o adolescente se separe progressivamente do núcleo familiar, opondo-se aos modelos parentais, aqui ele reconhece, valoriza e por vezes se acomoda dentro do papel de cuidado e 
dependente. Ao mesmo tempo, procura adaptar-se ao grupo de amigos, como que se assemelhando e encontrando o reforço necessário de autoconfiança que eventualmente algumas peculiaridades da doença e/ou tratamento Ihes faltam.

\section{$\underline{\text { Imagem Corporal }}$}

$\mathrm{Na}$ medida em que os corpos dos adolescentes mudam, eles percebem e sentem, olham e se movem de forma diferente do que antes e experimentam desconforto com excesso ou falta de peso, formas infantis mescladas com formas adultas conferindo desarmonia estética. Essas mudanças precisam ser absorvidas pelo adolescente, de modo que eles /ela sintam que esse novo corpo é parte dele ou dela. As imagens de corpo feminino e masculino glamourosas, que são vistas na televisão e em revistas tendem a estabelecer expectativas exageradas e impossíveis de serem alcançadas.

A Pesquisa Nacional de Saúde do Escolar PeNSE ${ }^{(76)}$ publicados em 2016, realizada em escolares através de duas amostras: uma delas frequentando o $9^{\circ}$ ano do ensino fundamental e a segunda amostra refere-se a escolares de 13 a 17 anos de idade frequentando as etapas de ensino de interesse. Ela caracteriza alguns indicadores de imagem corporal destes escolares, revelando que parcela expressiva dos escolares se sentia satisfeito ou muito satisfeito com o próprio corpo, sendo que o os mais novos representavam o grupo mais satisfeito, 72,4\% (13 a 15 anos) e 66,6\%, (16 a 17 anos). As proporções são menores entre as meninas quando comparadas aos meninos, em ambas as faixas etárias. E, ainda, mais de 80,0\% dos estudantes de 13 a 17 anos de idade consideravam a própria imagem corporal importante ou muito importante, sendo os maiores percentuais encontrados entre os escolares mais velhos e do sexo feminino; (85,7\% das meninas de 16 a 17 anos). Destaca-se ainda que 30,2\% das meninas de 13 a 15 anos e 32,6\% de 16 a 17 anos referiram que tentaram perder peso corporal. Entre os meninos, no entanto, $17,9 \%$ dos escolares de 13 a 15 anos de idade e $22,6 \%$ na faixa 
etária de 16 a 17 anos tentaram ganhar peso ou massa corporal. Naturalmente durante a adolescência sem condições crônicas, os profissionais de saúde permanecem atentos à relação entre nutrição adequada, em especial nas meninas, e atividade física apropriada, particularmente em meninos, e imagem corporal.

A primeira meta-análise publicada em 2013 por Pinquart, ${ }^{(98)}$ foram avaliados diversos estudos a respeito da imagem corporal num total de 30.209 crianças e adolescentes com doenças crônicas. Os maiores subgrupos tiveram obesidade ( $\mathrm{N}=9.019)$, câncer $(\mathrm{N}=3165)$, diabetes $(\mathrm{N}=2184)$, comprometimento visual $(N=1938)$, e asma ( $N=1393)$. A idade média de 13,3 anos ( $D P=2,6) ; 56 \%$ deles eram meninas e $31 \%$ eram membros de minorias étnicas. A idade média de início da doença foi de 4,1 anos. E mostrou que o tamanho as diferenças entre a imagem corporal de crianças e adolescentes com e sem doença crônica era específico da doença. As diferenças médias mais evidentes foram observadas em crianças com obesidade, fibrose cística e escoliose, portanto, em doenças visíveis para outros que afetavam a aparência. A obesidade difere das outras doenças por estar sempre visível para os outros. Ela é altamente estigmatizada, causando mais infelicidade do que o uso de cadeira de rodas ou em pacientes com desfiguração facial. ${ }^{(99)}$ Estudos disponíveis mostraram que crianças e adolescentes obesos são frequentemente vítimas de preconceito e estereótipos por pares, educadores e até mesmo pais. ${ }^{(100)(101)}$

Kaminsky estudou 46 adolescentes com diabetes tipo 1 e os comparou com 27 adolescentes saudáveis, escores Z do IMC foram obtidos por informações auto relatadas. Os participantes também completaram questionários validados que avaliaram a atividade física, imagem corporal, autoestima e apoio social. O IMC e os níveis de atividade física de adolescentes com diabetes tipo 1 não diferiram dos de adolescentes sem diabetes. Maior IMC estava associado a uma imagem corporal menos positiva e a menores resultados psicossociais, particularmente em meninas com diabetes. ${ }^{(102)}$

Estes estudos corroboram com os resultados de nossa pesquisa, pois destacam no grupo estudado sentimentos de constrangimento referentes à 
imagem corporal e seus efeitos sobre a autoestima. A obesidade não foi objeto do nosso estudo, no entanto os participantes com doenças renais e reumatológicas, devido ao uso prolongado de corticosteroides, eles experimentam períodos de obesidade e/ou edema variáveis e suas consequências.

Nesta pesquisa encontramos relatos de adolescentes, em especial do sexo feminino quando perguntadas sobre a visão da própria aparência. Seja pela doença ou tratamento, obesidade, menor estatura, fenótipo moon face, gerou sentimento de insegurança, autoexclusão social e frustração de expectativas

A adolescente relata:

"Ah, vou sair com meus amigos', porque quando eu estou inchada, eu me sinto muito feia... tenho vergonha..." (Fem., 15 anos)

Outro resultado pontua a idade de início da doença crônica, pois as doenças que afetam a aparência não tiveram efeito sobre imagem corporal em casos de doenças congênitas (fissura labial, paralisia cerebral). As crianças ajustam os padrões de aparência melhor que numa doença adquirida. Além disso, socialmente, os amigos podem se acostumar mais facilmente com a essas crianças antes que a aparência se torne muito importante na adolescência. $^{(102)}$

O adolescente revela:

“...eu queria ter nascido com Lúpus já... desde o começo já... teria acostumado de vez, rápido..." (Masc., 15 anos)

Este participante do presente estudo demonstra alguns aspectos do desenvolvimento da temporalidade da adolescência. A compreensão da duração da doença crônica não é simples para adolescentes, em especial os de fase inicial e para aqueles com diagnóstico mais recente que outros. $\mathrm{O}$ bom gerenciamento do tempo também requer o desenvolvimento de funções executivas, relacionadas com a maturação dos lobos pré-frontais, as últimas 
estruturas cerebrais para alcançar o pleno desenvolvimento. ${ }^{(32)}$ O adolescente precisa de tempo. Tempo de aceitação da doença e suas consequências. Tempo de equilibrar os sentimentos de perda do corpo da infância, e aquisição do corpo adolescente e este modificado pela doença. No entanto o padrão de tempo do adolescente é peculiar, as urgências são imensas e as postergações por vezes irracionais. Acrescenta-se a isso o imediatismo, a incapacidade de conviver com a insatisfação da espera. O que vemos nesta fala reflete a necessidade do adolescente de recorrer a um pensamento mágico que compense os danos que está sofrendo. ${ }^{(21,31)}$

O imediatismo próprio da adolescência em si já confere risco. Esta singularidade, a vivência singular temporal foi descrita por Aberastury e Knobel em 1981, ${ }^{(31)}$ é, na verdade, nos tempos atuais, característica de toda uma geração. Eles são velozes, têm energia entusiasmo, aprendem fácil, mas não têm paciência de esperar. Há uma inquietude interna, tudo vem rápido e vai rápido, o prazer, por exemplo, mas a dor e o desconforto nem sempre são fugazes. Ter nascido com doença, significa não ter que esperar se ajustar a ela, não enfrentar as modificações de aparência e suas consequências. A doença e seu tratamento impõem riscos relacionados à imagem da adolescência, como o estabelecimento do corpo ideal e a aceitação dos pares.

\section{Percepção de felicidade}

A definição de felicidade é complexa e desde a antiguidade encontramos definições no âmbito da filosofia e da psicologia. Aristóteles acreditava que toda ação humana visava a felicidade e a relacionava com a virtude, isto é não somente sentir-se bem mas ser bom. ${ }^{(103)} \mathrm{Na}$ visão da psicologia positiva, a felicidade tem não apenas um mas três elementos distintos. Primeiramente, a emoção positiva, isto é o prazer, o calor, êxtase, entusiasmo, conforto e sensações afins. Depois, o engajamento, onde empregamos todos nossos recursos e talentos pessoais para verdadeiramente se envolver com o mundo. E por fim, o sentido, pois todos os seres humanos desejam um propósito na vida. A vida com sentido consiste em pertencer e servir a algo maior que a si próprio. ${ }^{(104)(105)}$ 
O Relatório Mundial da Felicidade publicado em 2017 por Helliwell e colaboradores considera que a felicidade humana está baseada na saúde, sucesso financeiro, generosidade, relacionamentos de qualidade, confiança e liberdade de escolhas na vida. ${ }^{(106)}$

$\mathrm{Na}$ adolescência não se espera uma definição vitalícia sobre o tema, pois a busca de respostas sobre si mesmo e o mundo é incipiente. ${ }^{(31)}$ Uma pesquisa qualitativa através de entrevistas semiestruturadas com adolescentes entre 15-16 anos foi publicada em 2016 a respeito dos domínios e valor da felicidade em adolescente. Os domínios emergentes se referiam primeiro a pessoa, como estar saudável, ser alegre, ser inteligente e ter boa aparência. O segundo domínio se referia a posse, como ter família, ter amigos, ter propriedades e viver com luxo e o terceiro domínios ser referia a representação da pessoa para os outros e como subtemas encontrou-se: ser reconhecido pelos amigos, ter fama e poder, ter cargos políticos. E, em contrapartida, foi relacionado a sensação de infelicidade: não ter amigos ou família, estar doente, ter problemas com os pais, não ter acesso a escola e ter mau desempenho acadêmico, sofrer bullying, não ter dinheiro , não ter tempo livre e ser feio ou feia. ${ }^{(107)}$

Os adolescentes desta amostra relacionaram sua percepção de felicidade com as oportunidades de lazer como esporte, mídias e atividades relacionadas à música. Valorizaram os relacionamentos sociais com amigos, família e parceiros.

Desde o século $X X$, as mídias fazem parte do cotidiano em todas as idades. A geração Z, dos nascidos entre 1990 e 2010 na publicação de 2001 Marc Prensky ela foi chamada de Nativos Digitais. Eles representam as primeiras gerações que cresceram com esta nova tecnologia. Eles se desenvolveram cercados e usando computadores, vídeo games, tocadores de música digitais, câmeras de vídeo, telefones celulares, e as mensagens instantâneas são partes integrais de suas vidas. Assim como trocam os canais da TV de maneira rápida e constante com um controle remoto, em busca de algo que seja interessante de ver ou ouvir ou, ainda, por hábito. Os Nativos Digitais estão acostumados a receber informações muito rapidamente. Eles 
gostam de processar mais de uma coisa por vez e realizar múltiplas tarefas, e eles se divertem, fazem as tarefas escolares e se comunicam com os amigos ao mesmo tempo. ${ }^{(108)}$

Suris e colaboradores publicou em 2010 um estudo comparativo de uso de internet entre adolescentes com condições crônicas e seus pares a partir de banco do banco de dados SMASH (Swiss Multicente Adolescent Survey of Health) de 2002, um inquérito que inclui uma amostra nacionalmente representativa de ambos os sexos entre 16 a 20 anos através de duas perguntas: Com que frequência você estava conectado nos últimos 30 dias e por quanto tempo cada vez. Foram definidos quatro grupos de usuários de internet: usuários pesados (usuários diários por 2 horas), usuários regulares (<2 horas por dia ou qualquer duração, mas não todos os dias) usuários ocasionais (uma vez por semana ou menos) e não usuários. Os usuários da internet também foram questionados se tinham consultado quatro categorias de sites (saúde, incluindo sexualidade, lazer, estrelas de cinema/pessoas famosas e informações relacionadas ao trabalho escolar) e concluiu que as adolescentes com doenças crônicas do sexo feminino eram usuários mais frequentes e quatro vezes mais pesadas de Internet do que seus pares (> 2 horas diárias). E, para ambos os sexos, aqueles com condições crônicas tiveram maior probabilidade de ter acessado a internet em questões relacionadas à saúde, mas a diferença permaneceu significativa apenas para as mulheres. Não foram encontradas diferenças para as outras categorias de sites analisados. Para todos os grupos, os sites de lazer foram os mais visitados. ${ }^{(109)}$

Tsitsika e colaboradores publicaram em 2013 um estudo com dados coletados em seis países europeus: Grécia, Espanha, Polônia, Holanda, Romênia e Islândia. Participaram 10.930 adolescentes de 14 a 17 anos (idade média 15,8 \pm 7 anos), concluíram que as redes sociais são utilizadas por $70 \%$ dos adolescentes e $40 \%$ dos usuários passam duas ou mais horas diariamente nas redes sociais, classificado como uso pesado. Concluíram que uso pesado das redes sociais está associado a maior competência social para adolescentes mais velhos, e está associado a maiores problemas de 
internalização e pior desempenho acadêmicos, especialmente para adolescentes mais jovens. ${ }^{(110)}$

As redes sociais, fenômeno ainda mais recente, são parte da atividade grupal dos adolescentes e nos dados produzidos nesta pesquisa também foi mencionada como fonte de lazer. Vale ressaltar que eventualmente a escolha da diversão solitária e protegida atrás de uma tela de celular ou computador esconde o embaraço de alguns adolescentes que relutam em divulgar a natureza de sua condição ou tentam amenizar as limitações impostas ou evitam expor sua aparência aos colegas por medo de discriminação ou rejeição.

Entre as opções de diversão na amostra estudada, destacaram se aquelas relacionadas a esporte, atividade ao ar livre e as gastronômicas. A quadra de esporte, o parque, a praça de alimentação são os espaços preferidos para o encontro nos momentos de relaxamento e convivência. Mas estas atividades se confrontam com a dor, a restrição motora, as dietas restritivas e a proibição de exporem-se ao sol, presentes em alguns adolescentes com condições crônicas de saúde. Eles não são diferentes em desejos e aspirações dos amigos saudáveis, o adolescente como já mencionamos, é um ser grupal, mesmo entendendo suas limitações, permanece querendo estar com os amigos e sendo capaz de participar com eles destas práticas. É a uniformidade e identificação com o grupo que Ihes dá segurança e proteção.

As relações sociais desempenham um papel vital ao longo da vida. O Study of Adult Development ${ }^{(111)}$ começou em 1938, analisando 700 rapazes entre estudantes universidade de Harvard e moradores de bairros pobres de Boston, por sete décadas. Os participantes do estudo responderam, ao longo de décadas, questionários sobre sua família, seu trabalho e sua vida social, bem como tiveram acesso aos seus registros médicos, exames de imagem e testes laboratoriais. Foram feitas entrevistas com seus filhos e gravados vídeos dos participantes falando com suas esposas sobre suas preocupações mais profundas. A pesquisa acompanhou esses jovens durante toda a vida, monitorando seu estado mental, físico e emocional. Entre uma 
enorme quantidade de dados produzidos por estudo longitudinal, eles concluíram que as pessoas mais satisfeitas em seus relacionamentos, mais conectadas ao outro, com relações de qualidade onde existe suporte mútuo, permanecem saudáveis, física e mentalmente por mais tempo e vivem mais. (111)

Uma das pesquisas derivadas deste estudo de sete décadas, se refere ao ambiente da infância que foi avaliada durante visitas domiciliares e entrevistas com os pais dos entrevistados na entrada no estudo, no final da adolescência e nas idades 63, 73 e 78 anos como um preditor percepção de estado de saúde nestas idades mais avançadas. Este estudo apoia a hipótese de que a qualidade do ambiente da infância interfere na percepção da saúde nas idades estudadas. O ambiente da infância aumenta e promove 0 desenvolvimento de características psicológicas positivas nas crianças que quando adultos vêem e a sua saúde de forma mais positiva e favorável. Traços duradouros desenvolvidos na infância tais como otimismo, satisfação, vigor, domínio e autocontrole, até vitalidade e sensação de bem-estar subjetivo, podem predispor um adulto com auto percepção mais positiva de si mesmo e de sua saúde. ${ }^{(112)}$

Adquirir relacionamentos estreitos no grupo de amigos é uma tarefa de desenvolvimento particularmente importante na adolescência. Adolescentes com ligações fortes de onde obtêm suporte são mais bem aceitos, socialmente competentes, têm níveis mais elevados de autoestima, são mais ativos e tem melhor desempenho acadêmico. Além disso, as amizades seguras fornecem um amortecedor emocional contra sentimentos de sofrimento, bem como apoio psicológico e emocional. ${ }^{(113)}$

No entanto, para os adolescentes com doença crônica, esta tarefa de desenvolver relacionamentos entre os pares pode ser particularmente difícil porque as oportunidades de se envolver com colegas podem ser interrompidas por sintomas, tratamentos e absenteísmo escolar devido a hospitalização e consultas de seguimento. E é especialmente pior naqueles com doenças que possam causar algum tipo de constrangimento, cujos sintomas ou tratamento impõem limitações sociais. 
Helgeson em 2015 publicou uma revisão de estudos que consideram a visão dos pares de crianças e adolescentes com doenças crônicas. Traz informações relevantes já que não se podem desprezar os efeitos da doença crônica nas relações com os amigos e nem a influência destas relações na saúde. Um desses estudos foi realizado com colegas de classe de sobreviventes de tumores cerebrais e lesões traumáticas, verificando que os colegas de classe de crianças com lesões mais graves enxergaram a criança como sendo mais vitimada e rejeitada do que elas próprias. Desta mesma revisão, encontramos que alguns estudos que empregaram como informantes pais, professores, colegas de classe, e, alguns são auto relatados. Os resultados diferiam entre os informantes. Uma das possibilidades desta discrepância é que os pais sejam observadores mais precisos, tendo acesso a uma maior gama de informações do que seus filhos que não percebem deficiências no seu funcionamento ou relacionamentos sociais. No entanto, também é possível que as crianças e adolescentes com condições crônicas sejam mais precisos ao relatar suas próprias relações sociais do que os pais, e que os pais atribuem dificuldades sociais à doença crônica. ${ }^{(114)}$

Os estudos que relacionam aspectos de relacionamentos com os pares com resultados de saúde revelam associações tanto positivas quanto negativas. Existem várias explicações possíveis para essas descobertas inconsistentes. Pode ser que conexões fortes destas relações beneficiem o autoconceito e a saúde psicológica, mas à custa de comportamentos de saúde adaptativos. Ou seja, a imersão nas relações com os pares pode prejudicar o autocuidado. Também é possível que conexões fortes com os colegas tragam preocupações sobre os relacionamentos românticos mais proeminentes, levando a angústia elevada. Menos estudos se concentram nos aspectos negativos das relações entre pares, e estes encontraram vínculos entre relações conflituosas entre pares e resultados de saúde ruins. ${ }^{(115,116)}$

Em nosso estudo, a maioria dos relatos da relação com os pares foi positiva, e eles foram categóricos ao responder que a doença não os atrapalhava demasiadamente no convívio com amigos ou parceiros afetivos. É importante observar as maneiras pelas quais os adolescentes com doenças 
crônicas são semelhantes aos seus pares e capitalizar os pontos fortes deles, estimulando-os.

\section{Projeto de vida}

Assim como a busca de identidade permeia toda a adolescência dela derivam outras características próprias da mesma. Uma das características descritas por Aberatstury e Knobel, ${ }^{(31)}$ as manifestações contraditórias de conduta, costumam ser motivo de discórdia entre pais e filhos adolescentes. Adolescentes variam de humor, opiniões, desejos, escolhas profissionais, amores, tendências politicas e tudo que requeira decisões. Mas, para compreender melhor este comportamento, devemos pontuar que a adolescência é uma fase de transformações, de construção, de aquisição progressiva de conhecimento de si mesmo e do mundo. Quem tem certeza de tudo não tem nada a aprender. O adolescente se manifesta como consegue e não necessariamente como quer. Os recursos biológicos, psicológicos e sociais estão ainda sendo aperfeiçoados. Quanto mais jovens mais ambivalentes e mais mágicos são seus sonhos. Sonhos e projetos são necessários em qualquer época da vida e são reconhecidos como um fator de proteção. E, a despeito de não disporem da condição de saúde ideal, o adolescente adaptase, construindo pontes entre o sonho mágico e o sonho possível.

Griggs e colaboradores publicaram em 2016 uma revisão da literatura, buscando o que se conhece a respeito do papel da esperança em adolescentes com doenças crônicas. A partir de estudos quantitativos e qualitativos, emergiram temas, incluindo a esperança: promoção de saúde, melhora do enfrentamento e ajuste e melhora a qualidade de vida. Nesta revisão as pessoas que relataram níveis mais elevados de esperança encontraram caminhos para alcançar objetivos, vêem adversidades como desafios e gerenciam melhor os sintomas psicológicos. E sugere que também cabe ao profissional de saúde ajudar um adolescente com doenças crônicas a atingir seu potencial máximo. Devem ser oferecidas oportunidades para aproveitar os pontos fortes e os talentos de cada adolescente. ${ }^{(117)}$ 
Em nossa amostra, percebemos sonhos e projetos relativos às experiências que envolvem a doença e tratamento. As profissões desejadas são relativas aos cuidados de saúde, como medicina e nutrição ou as limitações como aquelas ligadas à prática esportiva ou restrições alimentares.

Dois dos respondentes nos relataram:

“...eu tinha um sonho de ser um jogador, mas como eu sou maior já, não dá mais para correr atrás, eu talvez de ser um treinador.." (Masc., cardiopata 16 anos) “...eu quero... eu tenho duas opções de faculdade, faculdade de gastronomia e nutrição..".(Fem., diabética,15 anos)

No ambulatório de especialidades pediátricas do Departamento de Pediatria da FCMSCSP, onde este estudo foi realizado, os pacientes são atendidos por médicos residentes, isto é, recém formados, em sua maioria por volta dos 25 anos. Notamos que os adolescentes, em especial os de longo tempo de seguimento, se identificam com eles, se interessam sobre suas histórias profissionais, como alcançaram seus objetivos, fascinados com o sucesso obtido. Na constante busca e descoberta de si mesmo, afastam se dos pais, e procuram outros modelos, e se espelham também nos médicos que os atendem, inclusive nas suas vidas profissionais. ${ }^{(31)}$

Como nos descreveu a adolescente:

“....eu quero fazer faculdade de medicina..."(Fem., 13 anos)

Os adolescentes com doenças crônicas têm projeto de vida, esperam realizar seus sonhos, pensam no futuro a despeito do seu estado de saúde. Acreditam no futuro, têm expectativas de melhora e até cura. É um fator de proteção que deve ser incentivado, que auxilia na adesão ao tratamento e controle da doença. 


\section{$\underline{\text { Relacionamento Médico-Paciente }}$}

Aspecto importante que emergiu dos grupos focais se refere ao relacionamento dos adolescentes com os profissionais de saúde que os atendem. Na Clínica de Adolescência do Departamento de Pediatria da FCMSCSP, o corpo docente investe no treinamento do residente de pediatria com foco no atendimento global, centrado no adolescente e não somente na condição de saúde. Adolescentes, vão adquirindo progressivamente independência de pais e cuidadores e não é possível fazer promoção de saúde ou prevenção de risco sem que se respeite, estimule e até, requeira autonomia gradativamente. Estes objetivos tornam-se mais difíceis de serem atingidos, sem vínculo adequado entre médico e paciente. Optamos pela construção desta relação por meio de agendamento de consultas em intervalos mais frequentes ao longo do seguimento e com duração que permita atendimento de consultas completas. Procuramos manter o acompanhamento no mesmo dia da semana, e, sempre que possível com o mesmo residente e sob supervisão do mesmo médico hebiatra assistente. Assim, apesar de queixas em relação a espera excessiva, eles podem ter um médico de referência e isso é valorizado por eles.

A consulta que tem caráter motivacional em lugar de impositiva, focando-se na pessoa mais que na doença são mais bem aceitas pelo adolescente. A entrevista motivacional é método clínico que foi testado em 1983 com pacientes dependentes de álcool, e na década de 90 com pacientes crônicos. Consiste numa técnica que visa encontrar nos pacientes motivação para mudanças comportamentais em benefício da própria saúde, baseados nos princípios de colaboração, entre médico e paciente, evocação dos recursos que o paciente já tem e que possam ser ativados em seu favor e respeito a autonomia do paciente, pois é possível aconselhar informar e até advertir, mas cada indivíduo faz suas próprias escolhas a partir da sua autonomia. Eventualmente o reconhecimento das próprias limitações do cuidador abre uma porta para a real mudança desejada. ${ }^{(118)}$

Alguns exemplos de como que eles manifestaram desejo de participação ativa no seu tratamento e melhora da comunicação : 
“... acho que eles deveriam tratar a gente mesmo como adolescentes e não como um doente, que você não pode fazer quase nada... e também ser um pouco mais pacientes, porque muitas vezes a gente não sabe se eles querem que a gente responda ou os nossos pais..."(Fem., 16 anos)

“...quando tomava remédio eles falavam com a minha mãe, não falavam comigo... tipo as instruções, não falavam para mim... seria legal saber o que eu vou fazer, o que eu vou tomar"(Fem., 16 anos)

Nos Ambulatórios de Especialidades Pediátricas do Departamento de Pediatria da FCMSCSP, nem sempre a fluxo de atendimento permite intervalos mais curtos entre as consultas de seguimento e as consultas tendem a ser mais breves que na Clínica de Adolescência, direcionadas ao ajuste fino do diagnóstico e do tratamento, e na maioria das vezes na presença dos pais. Desta forma, a parceria entre o hebiatra e o especialista torna-se ainda mais relevante, pois ela promove um elo entre família, adolescente e é facilitadora da promoção de saúde, adesão e autonomia. A despeito destas dificuldades, na nossa amostra, que foi constituída quase que exclusivamente por adolescentes em seguimento apenas nos Ambulatórios de Especialidades Pediátricas, os participantes se mostraram vinculados positivamente com seus pediatras especialistas, até mesmo com alguns de seus médicos residentes, referindo-se a eles pelo nome e foram feitos elogios:

"ah, eu gosto, já me acostumei... às vezes eu chego na sala e vejo um médico diferente - ué, cadê aquela doutora? -, às vezes é a Dra. Ciça ou a Claudete..., aí depois de um tempo ela vem e entra na sala"(Masc., 16 anos)

E neste exemplo, observamos como a adolescente enxerga empatia em seu médico:

“...eu me sinto bem por ser atendida aqui, os médicos sempre falam de igual para igual, eles dão conselhos, eles não chegam te dando bronca, eles falam ah... isso aqui é melhor para você... -, - o jeito que está fazendo não está 
certo... não está dando certo, tem que mudar -. Isso eu acho legal, não chegam tipo 'eu sou mais que você, porque você é paciente e eu sou médico'”'(Fem., 15

A empatia é considerada um componente básico de todas as relações se representa um dos domínios centrais das habilidades sociais e de comunicação e é frequentemente associada a melhores resultados diagnósticos e terapêuticos. Na relação médico-paciente a empatia contribui com alguns aspectos como comunicação interpessoal, compreensão das percepções e necessidades do paciente e a capacidade de comunicar esse entendimento ao paciente. ${ }^{(119)}$

A relação da empatia com resultados diagnósticos e terapêuticos favoráveis no contexto clínico tem merecido atenção no treinamento médico. ${ }^{(120)}$ Acreditamos que a rotação de médicos residentes e internos, em estágios práticos que incluam atendimento de adolescentes, favorece 0 desenvolvimento habilidades da comunicação verbal não verbal. As estratégias empregadas na Clínica de Adolescência do Departamento de Pediatria da FCMSCSP para ensinar habilidades da comunicação merecem estudos específicos.

Os melhores resultados da assistência destes adolescentes são alcançados incluindo a compreensão do desenvolvimento emocional e cognitivo em cada fase da adolescência. Tais como, a progressiva substituição da sensação de invulnerabilidade pela capacidade de organização e convicção, a valorização do cuidado parental e mesmo do grupo de amigos.

A adesão irregular ao tratamento médico é um problema comum em pacientes com doenças crônicas. Hanghøj e colaboradores publicaram uma revisão sistemática em 2013 com objetivo de identificar as barreiras de adesão em uma variedade de condições crônicas a partir da própria perspectiva dos adolescentes. Vinte e oito estudos foram avaliados num total 2.501 participantes adolescentes com variadas condições crônicas. A partir de análise temática e foram identificadas as categorias: relações (pares, pais, profissionais de saúde); desenvolvimento do adolescente (luta pela normalidade, liberdade versus controle); saúde e doença (bem-estar físico e 
mental, percepções de tratamento e preocupações); esquecimento (esquecer por atividades, esquecer por coincidência); organização; complexidade da medicina; custos financeiros. Em relação aos profissionais de saúde, entre as dificuldades encontradas nos estudos revisados foi encontrada uma correlação estatisticamente significativa entre o apoio de profissionais de saúde e a adesão tanto para asma, epilepsia, diabetes mellitus insulinodependente e artrite reumatoide. A falta de apoio dos profissionais de saúde parece estar relacionada à comunicação com os adolescentes que expressaram seu desejo de ser tratados como adultos, porque já não se sentiam como crianças. Entre as queixas dos adolescentes estão a compreensão adequada das expectativas de seu tratamento e da natureza do transtorno, impessoalidade, frieza e o "olhar" para computador e não ao paciente e ainda, relataram que eles receberam mais atenção dos médicos, quando eles descontinuaram o tratamento. Desta forma, percebe-se que algumas barreiras parecem ser específicas da adolescência e o conhecimento dessas pode melhorar as intervenções clínicas. ${ }^{(121)}$

Alcançar adesão e controle de doenças crônicas consiste numa tarefa que requer outras ferramentas na adolescência. Uma recente revisão a respeito de asma na adolescência, publicada em 2017 sugere que o paciente deve conhecer sua doença e o tratamento, entendendo que pode ser necessária uma terapia vitalícia. Deve se investir tempo na discussão diretamente com o adolescente, levantando suas expectativas, para obter um bom plano de gerenciamento, incluindo os esportes e o desempenho escolar. $\mathrm{E}$, como o controle da asma está relacionado à adesão, o uso de dispositivos eletrônicos para inaladores de medicação preventiva, com lembretes audiovisuais podem sem úteis. Além disso, levanta possibilidades de suporte online através de salas ou fóruns de asma, pois a mídia social desempenha um papel crescente na vida diária dos adolescentes e recomenda que aqueles envolvidos nos cuidados devam aprender a utilizar este recurso em favor da adesão e sustentação do tratamento. ${ }^{(122)}$

O profissional de saúde, em ordem de conseguir atingir os objetivos de adesão: uso correto da medicação, mudança de estilo de vida e 
seguir dietas, estabelecem uma abordagem contratual, negociando passo a passo em seguimento contínuo e frequente, favorecendo a autonomia para gestão do tratamento do próprio adolescente.

\section{Limitações e força do estudo}

Uma limitação do estudo refere-se aos dados quantitativos obtidos a partir da fase I. A amostra foi pequena e os resultados se prestaram principalmente para caracterizar a população. Em relação a seleção dos instrumentos escolhidos, isto é, foram aplicados questionários validados, mas não específicos para adolescentes. Contundo há que se considerar a idade e capacidade cognitiva dos respondentes.

Este estudo apresentou como ponto forte a possibilidade de conhecer a auto percepção do estado de saúde, e sua influência na qualidade vida, a relação desta com a evolução da adolescência, o desenvolvimento de estratégias de enfrentamento às limitações impostas pela doença e tratamento e ainda aspectos da relação médico-paciente.

Outra força do estudo foi possibilitar aos adolescentes um espaço de escuta qualificado para expressar suas opiniões e de tê-las respeitadas e por isso incentivamos a inclusão de adolescentes como sujeitos de pesquisa e na produção de dados, sem interferência do adulto, em ambas as fases da pesquisa.

O diferencial do estudo também reside na combinação de duas metodologias aplicadas consecutivamente na produção dos dados.

E finalmente, o estudo pode contribuir com o aprimoramento do cuidado, na medida em que, devolve à instituição, corpo clínico e docente dos Ambulatórios de Especialidades Pediátricas do Departamento de Pediatria da FCMSCSP, a perspectiva de seus pacientes sobre sua doença, tratamento e relação médico-paciente. E, abre possibilidades de incentivar no ensino da faculdade de medicina, aspectos levantados nesta tese. 


\section{Conclusões}

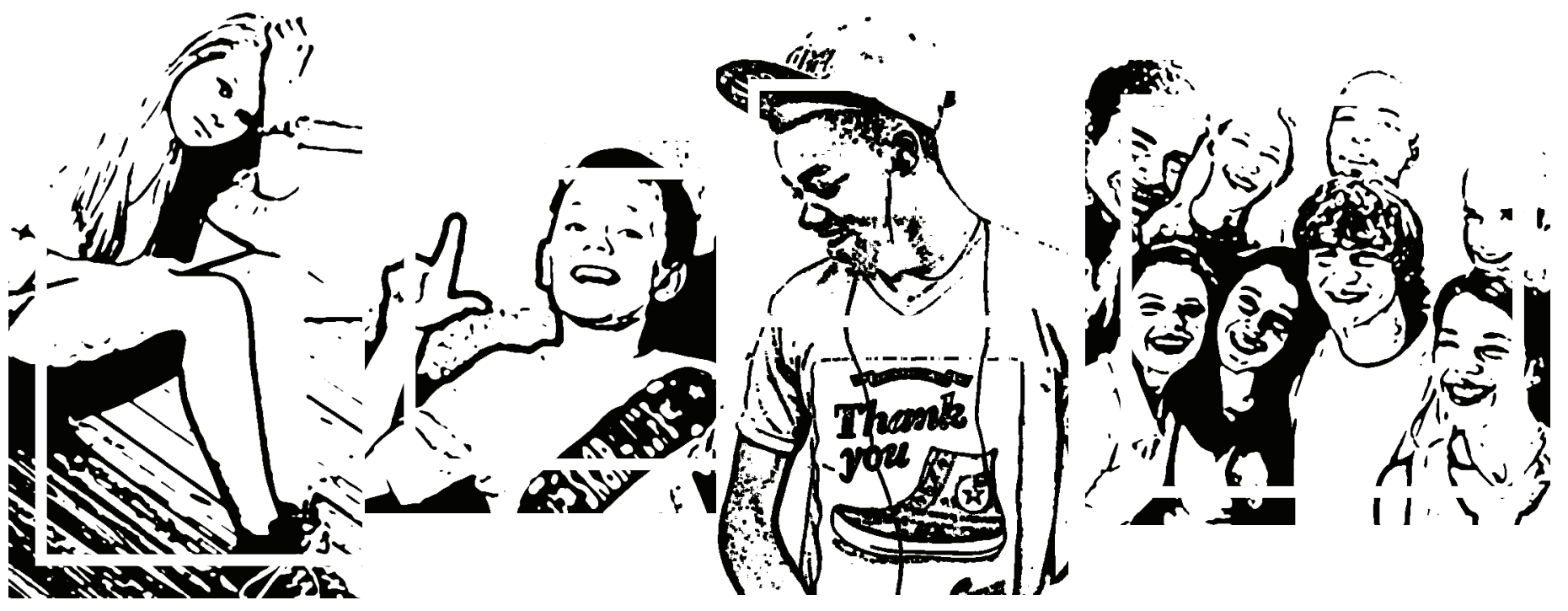




\section{CONCLUSÃO e CONSIDERAÇÕES FINAIS}

Com base na análise e discussão dos resultados encontrados no presente estudo, conclui-se que a condição de saúde dos adolescentes da amostra não alterou a percepção da qualidade de vida auto relatada ou através do questionário WHOQOL-Bref, exceto entre os adolescentes menores de 15 anos que têm escores mais elevados no Domínio Relações Sociais.

Os adolescentes da pesquisa têm sentimentos ambíguos em relação à percepção da doença e suas limitações.

A despeito da doença crônica, os adolescentes da pesquisa têm sonhos, desejos e comportamentos sociais esperados de um indivíduo saudável nesta fase. A doença crônica tem impacto na socialização e escolarização do adolescente e aqueles com maiores escores de resiliência tiveram menos atraso escolar. Os adolescentes pesquisados desenvolvem comportamentos sociais adaptativos, com apoio de pais e amigos.

O adolescente com doença crônica deseja e tem condições de participar do seu processo terapêutico considerando as particularidades da adolescência em todas as fases.

Neste contexto e possível reafirmar a valoração da transição entre o cuidado pediátrico para o cuidado de clínico geral e de especialistas, pois auxiliar adolescentes com condições crônicas de saúde a construir competências de autocuidado e relacionais, fortalecer suas conexões com a família, com a comunidade, com o grupo de amigos e profissionais de saúde, pode em muito contribuir com sua saúde e qualidade de vida.

O êxito em um processo terapêutico consiste também em tirar o adolescente do lugar de expectador e mero ouvinte e colocá-lo no lugar de ator. Desta forma o adolescente não deve ser vítima de sua doença, mas sujeito do seu tratamento

Dar voz ao adolescente com condições crônicas dentro de um serviço terciário de saúde foi condição inicial e fundamental neste estudo. 


\section{Anexos}

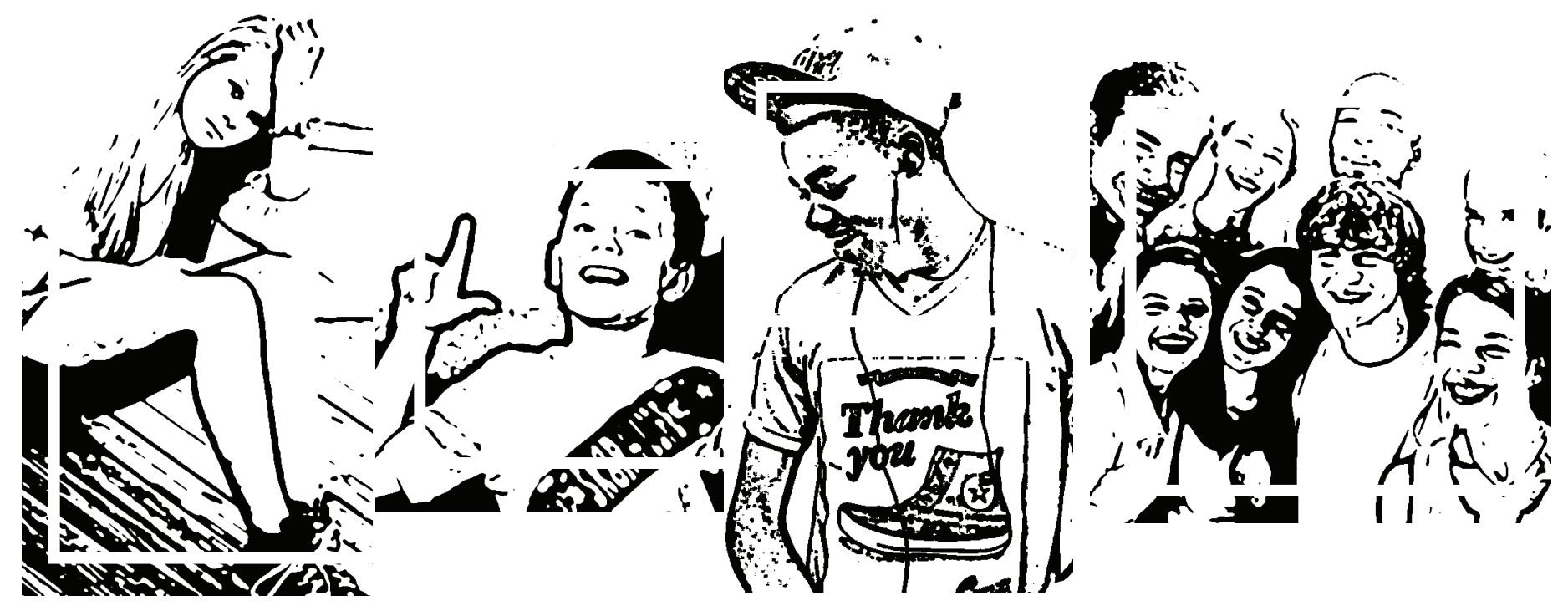


ANEXOS

1. Termo de Consentimento Livre e Esclarecido

2. Questionário sócio demográfico

3. WHOQOL-BREF (Fleck et al.1999)

4. RS - 14 (ResilienceScale)-Escala de Resiliência de Wagnild\& Young

5. Autorizações

6. Termo de Compromisso

7. Parecer Consubstanciado do Comitê de Ética e Pesquisa da Irmandade da Santa Casa de Misericórdia de São Paulo

8. Aprovação do Comitê de Ética e Pesquisa da Faculdade de Medicina da Universidade de São Paulo 
Anexo I - Termo De Consentimento Livre e Esclarecido

Faculdade de Medicina Da Universidade da São Paulo

Faculdade de Ciências Médicas da Santa Casa De Misericórdia De S Paulo Termo De Consentimento Livre e Esclarecido

Dados de identificação do sujeito da pesquisa ou responsável legal

Nome:

Documento de identidade $\mathrm{n}^{0}$ :

Sexo: $M \square F \square$

Data nascimento: .......................

Endereço ....................................... N $\mathrm{N}^{0} \ldots \ldots \ldots \ldots \ldots \ldots$ Apto: bairro:

Cidade CEP:

Telefone: DDD

..)

Responsável legal.

Natureza (grau de parentesco, tutor, curador etc.)

Documento de identidade:

Sexo: $m \square f \square$

Data de nascimento: ...................

Endereço: $\mathrm{N}^{\mathrm{O}}$

Apto:

Bairro: Cidade:

CEP: Telefone: DDD

$(\ldots \ldots \ldots \ldots)$ 
Dados sobre a pesquisa

Título do protocolo de pesquisa Qualidade De Vida, Adolescência e Doença Crônica.

Pesquisadores:

Prof. Dr. ${ }^{a}$ Patrícia Tempski.( Médica Pesquisadora do CEDEM, Centro de Desenvolvimento de Educação Médica da FMUSP)

Silvia Maria Balieiro Nigro

1-As informações que se seguem estão sendo fornecidas para sua participação voluntária neste estudo, que tem por objetivo central conhecer a percepção do adolescente acerca da sua qualidade de vida no curso do diagnóstico e seguimento de sua doença e identificar fatores interrelacionados a uma melhor ou pior qualidade de vida.

2-Buscando conhecer melhor a realidade dos adolescentes, estes participarão de reuniões com outros jovens e a pesquisadora onde haverá uma discussão aberta sobre os temas diversos relacionados com a adolescência e qualidade de vida. A inclusão no estudo se dará a partir dos bancos de dados dos ambulatórios escolhidos para participar da pesquisa. A participação é voluntária.

3-A participação no estudo varia por volta de 120 minutos. Aos participantes será oferecido acesso aos dados e devolutiva dos seus resultados.

4-Garantia de acesso: em qualquer etapa do estudo, você terá acesso aos profissionais responsáveis pela pesquisa para esclarecimento de eventuais dúvidas. O principal investigador é Silvia Maria Balieiro Nigro. Se você tiver alguma consideração ou dúvida sobre a ética da pesquisa, entre em contato com o Comitê de Ética em Pesquisa (CEP) -Av. Dr. Arnaldo, 455 - Instituto Oscar Freire $-1^{\circ}$ andar- tel.: 3061-8004 FAX: 3061-8004- E-mail:

cep.fmusp@hcnet.usp.br.

É garantida a liberdade da retirada de consentimento a qualquer momento e deixar de participar do estudo, sem qualquer prejuízo.

5-Direito de confidencialidade - As informações obtidas serão analisadas em conjunto com outros pacientes, não sendo divulgada a identificação de nenhum paciente.

6-Despesas e compensações: não há despesas pessoais para o participante em qualquer fase do estudo. Também não há compensação financeira relacionada à sua participação. Se existir qualquer despesa adicional, ela será absorvida pelo orçamento da pesquisa. 
7-Compromisso do pesquisador de utilizar os dados e o material coletado somente para esta pesquisa.

Acredito ter sido suficientemente informado a respeito das informações que li ou que foram lidas para mim, descrevendo o estudo: Qualidade de vida, adolescência e doença crônica.

Eu discuti com as pesquisadoras sobre a minha decisão em participar nesse estudo. Ficaram claros para mim quais são os propósitos do estudo, os procedimentos a serem realizados, seus desconfortos e riscos, as garantias de confidencialidade e de esclarecimentos permanentes. Ficou claro também que minha participação é isenta de despesas e que tenho garantia do acesso a tratamento quando necessário. Concordo voluntariamente em participar deste estudo e poderei retirar o meu consentimento a qualquer momento, antes ou durante o mesmo, sem penalidades ou prejuízo ou perda de qualquer benefício que eu possa ter adquirido.

Concordo também nos registros fotográficos e de áudio realizados com a minha participação neste estudo.

Assinatura do paciente

Assinatura do representante legal

Data 1

Assinatura da testemunha

Data 11

Para casos de pacientes menores de 18 anos, analfabetos, semianalfabetos ou portadores de deficiência auditiva ou visual.

\section{(Somente para o responsável do projeto)}

Declaro que obtive de forma apropriada e voluntária o Consentimento Livre e Esclarecido deste paciente ou representante legal para a participação neste estudo. 


\section{Anexo II - QUESTIONÁRIO SÓCIO-DEMOGRÁFICO}

Nome:

Documento de identidade $n^{\circ}$ : RG SC.....

Sexo: $M \square F \square$

Data nascimento:

1. Com quem você reside?

1. Com os pais ( )

2. Com outros parentes ( ), quem?

3. Com amigo(s) ( )

4. Sozinho ( )

5. Outros:

2. Você está estudando? Sim ( ) Não ( )

1. Qual ano você está cursando?

3. Já perdeu algum ano? Sim ( ) Não ( )

Quando?

1. Relacionado com doença/tratamento? Sim ( ) Não ( )

4. Já teve dificuldade escolar Sim ( ) Não ( )

Qual?

5. Você trabalha? Sim ( ) Não ( )

1. Tem registro em carteira $\operatorname{Sim}($ ) Não ( )

2. Estagiário Sim ( ) Não ( )

3. Jovem aprendiz $\operatorname{Sim}($ ) Não ( )

4. Sua renda é importante no seu sustento ou da família Sim ( ) Não ( )

6. Você já esteve internado? Sim ( ) Não ( )

1. Quantas vezes?

2. Por quanto tempo?

3. A última internação foi há quanto tempo?

7. Você toma medicação? Sim () Não ( ) 
8. Quem controla sua medicação e seus retornos no médico?

9. Com quem você mais conta para te ajudar?

Dê uma nota de 0 a 10 para sua qualidade de vida geral

\begin{tabular}{|l|l|l|l|l|l|l|l|l|l|l|}
\hline 0 & 1 & 2 & 3 & 4 & 5 & 6 & 7 & 8 & 9 & 10 \\
\hline & & & & & & & & & & \\
\hline
\end{tabular}


ANEXO III-WHOQOL - ABREVIADO

INSTRUMENTO ABREVIADO DE AVALIAÇÃO DA QUALIDADE DE VIDA

\section{Instruções}

Este questionário é sobre como você se sente a respeito de sua qualidade de vida, saúde e outras áreas de sua vida. Por favor, responda a todas as questões. Se você não tem certeza sobre que resposta dar em uma questão, por favor, escolha entre as alternativas a que lhe parece mais apropriada. Esta, muitas vezes, poderá ser sua primeira escolha.

Por favor, tenham em mente seus valores, aspirações, prazeres e preocupações. Nós estamos perguntando o que você acha de sua vida, tomando como referência as duas últimas semanas. Por exemplo, pensando nas últimas duas semanas, uma questão poderia ser:

\begin{tabular}{|c|c|c|c|c|c|}
\hline & Nada & $\begin{array}{c}\text { Muito } \\
\text { pouco }\end{array}$ & Médio & Muito & Completamente \\
\hline $\begin{array}{c}\text { Você recebe dos } \\
\text { outros o apoio de } \\
\text { que necessita? }\end{array}$ & 1 & 2 & 3 & 4 & 5 \\
\hline
\end{tabular}

Você deve circular o número que melhor corresponde ao quanto você recebe dos outros o apoio de que necessita nestas últimas duas semanas.

Portanto, você deve circular o número 4 se você recebeu "muito" apoio como abaixo. 


\begin{tabular}{|c|c|c|c|c|c|}
\hline & Nada & $\begin{array}{c}\text { Muito } \\
\text { pouco }\end{array}$ & Médio & Muito & Completamente \\
\hline $\begin{array}{c}\text { Você recebe dos } \\
\text { outros o apoio de } \\
\text { que necessita? }\end{array}$ & 1 & 2 & 3 & (4) & 5 \\
\hline
\end{tabular}

Você deve circular o número 1 se você não recebeu "nada" de apoio.

Por favor, leia cada questão, veja o que você acha e circule no número e lhe parece a melhor resposta.

\begin{tabular}{|c|c|c|c|c|c|c|c|c|}
\hline & & $\begin{array}{l}\text { Muito } \\
\text { ruim }\end{array}$ & Ruim & $\begin{array}{l}\mathrm{Ne} \\
\text { ruil } \\
\text { ne } \\
\text { bo }\end{array}$ & & Boa & \multicolumn{2}{|l|}{ Muito boa } \\
\hline 1 & $\begin{array}{l}\text { Como você } \\
\text { avaliaria sua } \\
\text { qualidade de } \\
\text { vida? }\end{array}$ & 1 & 2 & 3 & & 4 & \multicolumn{2}{|l|}{5} \\
\hline & & $\begin{array}{l}\text { Muito } \\
\text { insatis } \\
\text { feito }\end{array}$ & \multicolumn{4}{|c|}{$\begin{array}{l}\text { Nem } \\
\text { satisfeito } \\
\text { nem } \\
\text { insatisfeito }\end{array}$} & Satisfeito & $\begin{array}{l}\text { Muito } \\
\text { Satisfeito }\end{array}$ \\
\hline
\end{tabular}




\begin{tabular}{|c|c|c|c|c|c|c|}
\hline 2 & $\begin{array}{l}\text { Quão } \\
\text { satisfeito } \\
\text { (a) você } \\
\text { está com } \\
\text { a sua } \\
\text { saúde? }\end{array}$ & 1 & 2 & 3 & 4 & 5 \\
\hline
\end{tabular}

As questões seguintes são sobre o quanto você tem sentido algumas coisas nas últimas duas semanas.

\begin{tabular}{|c|c|c|c|c|c|c|}
\hline & & Nada & $\begin{array}{l}\text { Muito } \\
\text { pouco }\end{array}$ & $\begin{array}{l}\text { Mais } \\
\text { ou } \\
\text { menos }\end{array}$ & Bastante & Extremamente \\
\hline 3 & $\begin{array}{l}\text { Em que medida você acha } \\
\text { que sua dor (física) impede } \\
\text { você de fazer o que você } \\
\text { precisa? }\end{array}$ & 1 & 2 & 3 & 4 & 5 \\
\hline 4 & $\begin{array}{l}\text { O quanto você precisa de } \\
\text { algum tratamento médico } \\
\text { para levar sua vida diária? }\end{array}$ & 1 & 2 & 3 & 4 & 5 \\
\hline 5 & $\begin{array}{l}\text { O quanto você aproveita a } \\
\text { vida? }\end{array}$ & 1 & 2 & 3 & 4 & 5 \\
\hline 6 & $\begin{array}{l}\text { Em que medida você acha } \\
\text { que a sua vida tem sentido? }\end{array}$ & 1 & 2 & 3 & 4 & 5 \\
\hline
\end{tabular}




\begin{tabular}{|l|l|l|l|l|l|l|}
\hline 7 & $\begin{array}{l}\text { O quanto você consegue se } \\
\text { concentrar? }\end{array}$ & 1 & 2 & 3 & 4 & 5 \\
\hline 8 & $\begin{array}{l}\text { Quão seguro (a) você se } \\
\text { sente em sua vida diária? }\end{array}$ & 1 & 2 & 3 & 4 & 5 \\
\hline 9 & $\begin{array}{l}\text { Quão saudável é o seu } \\
\text { ambiente físico (clima, } \\
\text { barulho, poluição, } \\
\text { atrativos)? }\end{array}$ & 1 & 2 & 3 & 4 & 5 \\
\hline
\end{tabular}

As questões seguintes perguntam sobre quão completamente você tem sentido ou é capaz de fazer certas coisas nestas últimas duas semanas.

\begin{tabular}{|l|l|l|l|l|l|l|}
\hline & & Nada & $\begin{array}{l}\text { Muito } \\
\text { pouco }\end{array}$ & Médio & Muito & Completamente \\
\hline 10 & $\begin{array}{l}\text { Você tem energia } \\
\text { suficiente para seu dia- } \\
\text { a-dia? }\end{array}$ & 1 & 2 & 3 & 4 & 5 \\
\hline 11 & $\begin{array}{l}\text { Você é capaz de aceitar } \\
\text { sua aparência física? }\end{array}$ & 1 & 2 & 3 & 4 & 5 \\
\hline 12 & $\begin{array}{l}\text { Você tem dinheiro } \\
\text { suficiente para }\end{array}$ & 1 & 2 & 3 & 4 & 5 \\
\hline
\end{tabular}




\begin{tabular}{|c|c|c|c|c|c|c|}
\hline & $\begin{array}{l}\text { satisfazer suas } \\
\text { necessidades? }\end{array}$ & & & & & \\
\hline 13 & $\begin{array}{l}\text { Quão disponíveis para } \\
\text { você estão às } \\
\text { informações que } \\
\text { precisa no seu dia-a- } \\
\text { dia? }\end{array}$ & 1 & 2 & 3 & 4 & 5 \\
\hline 14 & $\begin{array}{l}\text { Em que medida você } \\
\text { tem oportunidades de } \\
\text { atividade de lazer? }\end{array}$ & 1 & 2 & 3 & 4 & 5 \\
\hline
\end{tabular}

As questões seguintes perguntam sobre quão bem ou satisfeito você se sentiu a respeito de vários aspectos de sua vida nas últimas duas semanas.

\begin{tabular}{|l|l|l|l|l|l|c|}
\hline & Muito ruim & Ruim & $\begin{array}{l}\text { Nem ruim } \\
\text { nem bom }\end{array}$ & Bom & $\begin{array}{c}\text { Muito } \\
\text { bom }\end{array}$ \\
\hline 15 & $\begin{array}{l}\text { Quão bem você } \\
\text { é capaz de se } \\
\text { locomover? }\end{array}$ & 1 & 2 & 3 & 4 & 5 \\
\hline & $\begin{array}{l}\text { Muito } \\
\text { insatisfeito }\end{array}$ & Insatisfeito & $\begin{array}{l}\text { satisfeito } \\
\text { nem } \\
\text { insatisfeito }\end{array}$ & Satisfeito & Muito \\
satisfeito
\end{tabular}




\begin{tabular}{|c|c|c|c|c|c|c|}
\hline 16 & $\begin{array}{l}\text { Quão satisfeito } \\
\text { (a) você está } \\
\text { com o seu } \\
\text { sono? }\end{array}$ & 1 & 2 & 3 & 4 & 5 \\
\hline 17 & $\begin{array}{l}\text { Quão satisfeito } \\
\text { (a) você está } \\
\text { com sua } \\
\text { capacidade de } \\
\text { desempenhar } \\
\text { as atividades } \\
\text { do seu dia-a- } \\
\text { dia? }\end{array}$ & 1 & 2 & 3 & 4 & 5 \\
\hline 18 & $\begin{array}{l}\text { Quão satisfeito } \\
\text { (a) você está } \\
\text { com sua } \\
\text { capacidade } \\
\text { para o } \\
\text { trabalho? }\end{array}$ & 1 & 2 & 3 & 4 & 5 \\
\hline 19 & $\begin{array}{l}\text { Quão satisfeito } \\
\text { (a) você está } \\
\text { consigo } \\
\text { mesmo? }\end{array}$ & 1 & 2 & 3 & 4 & 5 \\
\hline
\end{tabular}




\begin{tabular}{|c|c|c|c|c|c|c|}
\hline 20 & $\begin{array}{l}\text { Quão satisfeito } \\
\text { (a) você está } \\
\text { com suas } \\
\text { relações } \\
\text { pessoais } \\
\text { (amigos, } \\
\text { parentes, } \\
\text { conhecidos, } \\
\text { colegas)? }\end{array}$ & 1 & 2 & 3 & 4 & 5 \\
\hline 21 & $\begin{array}{l}\text { Quão satisfeito } \\
\text { (a) você está } \\
\text { com sua vida } \\
\text { sexual? }\end{array}$ & 1 & 2 & 3 & 4 & 5 \\
\hline 22 & $\begin{array}{l}\text { Quão satisfeito } \\
\text { (a) você está } \\
\text { com } \\
\text { o apoio que } \\
\text { você recebe de } \\
\text { seus amigos? }\end{array}$ & 1 & 2 & 3 & 4 & 5 \\
\hline 23 & $\begin{array}{l}\text { Quão satisfeito } \\
\text { (a) você está } \\
\text { com } \\
\text { as condições } \\
\text { do local onde } \\
\text { mora? }\end{array}$ & 1 & 2 & 3 & 4 & 5 \\
\hline 24 & $\begin{array}{l}\text { Quão satisfeito } \\
\text { (a) você está }\end{array}$ & 1 & 2 & 3 & 4 & 5 \\
\hline
\end{tabular}




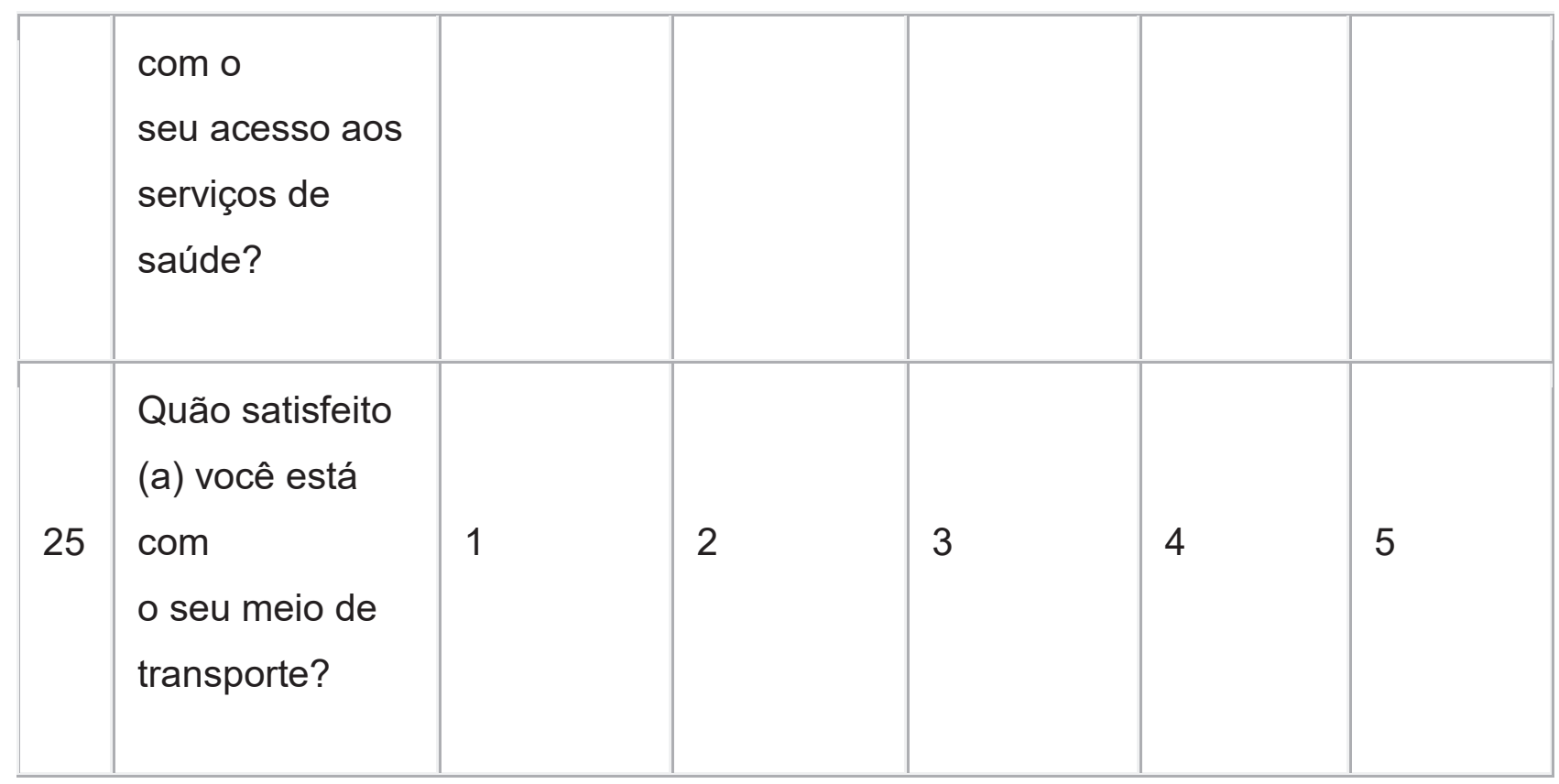

As questões seguintes referem-se a com que frequência você sentiu ou experimentou certas coisas nas últimas duas semanas.

\begin{tabular}{|l|l|l|l|l|l|}
\hline & Nunca & $\begin{array}{l}\text { Algumas } \\
\text { vezes }\end{array}$ & Frequentemente & $\begin{array}{l}\text { Muito } \\
\text { frequentemente }\end{array}$ & Sempre \\
\hline $\begin{array}{l}\text { Com que } \\
\text { frequência } \\
\text { você tem } \\
\text { sentimentos } \\
\text { negativos } \\
\text { tais como } \\
\text { mau humor, } \\
\text { desespero, } \\
\text { ansiedade, } \\
\text { depressão? }\end{array}$ & 1 & 2 & 3 & 4 & 5 \\
\hline
\end{tabular}

Alguém Ihe ajudou a preencher este questionário?

Quanto tempo você levou para preencher este questionário? 
ANEXO IV - RS - 14 (ResilienceScale)-Escala de Resiliência de Wagnild\& Young

Por favor, leia as alternativas com atenção e responda a escala de sete números, na qual 7 significa concordo fortemente e 1 discordo fortemente.

\begin{tabular}{|c|c|c|c|c|c|c|c|}
\hline & & orc & & & & en & \\
\hline $\begin{array}{l}\text { 1. Eu costumo lidar com os problemas de } \\
\text { uma forma ou de outra. }\end{array}$ & 1 & 2 & 3 & 4 & 5 & 6 & 7 \\
\hline $\begin{array}{l}\text { 2. Sinto orgulho de ter realizado coisas na } \\
\text { minha vida. }\end{array}$ & 1 & 2 & 3 & 4 & 5 & 6 & 7 \\
\hline $\begin{array}{l}\text { 3. Quando faço planos, eu os levo até o } \\
\text { fim. }\end{array}$ & 1 & 2 & 3 & 4 & 5 & 6 & 7 \\
\hline 4. Eu sou amigo de mim mesmo. & 1 & 2 & 3 & 4 & 5 & 6 & 7 \\
\hline $\begin{array}{l}\text { 5. Eu sinto que posso lidar com várias } \\
\text { coisas ao mesmo tempo. }\end{array}$ & 1 & 2 & 3 & 4 & 5 & 6 & 7 \\
\hline 6. Eu sou determinado. & 1 & 2 & 3 & 4 & 5 & 6 & 7 \\
\hline $\begin{array}{l}\text { 7. Eu posso enfrentar tempos difíceis } \\
\text { porque já experimentei dificuldades antes. }\end{array}$ & 1 & 2 & 3 & 4 & 5 & 6 & 7 \\
\hline 8. Eu sou disciplinado. & 1 & 2 & 3 & 4 & 5 & 6 & 7 \\
\hline 9. Eu mantenho interesse nas coisas. & 1 & 2 & 3 & 4 & 5 & 6 & 7 \\
\hline $\begin{array}{l}\text { 10. Eu normalmente posso achar motivo } \\
\text { para rir. }\end{array}$ & 1 & 2 & 3 & 4 & 5 & 6 & 7 \\
\hline $\begin{array}{l}\text { 11. Minha crença em mim mesmo me leva a } \\
\text { atravessar tempos difíceis. }\end{array}$ & 1 & 2 & 3 & 4 & 5 & 6 & 7 \\
\hline 12. Em uma emergência, eu sou uma & 1 & 2 & 3 & 4 & 5 & 6 & 7 \\
\hline
\end{tabular}




\begin{tabular}{|l|l|l|l|l|l|l|l|}
\hline pessoa em quem as pessoas podem contar. & & & & & & & \\
\hline 13. Minha vida tem sentido. & 1 & 2 & 3 & 4 & 5 & 6 & 7 \\
\hline $\begin{array}{l}\text { 14. Quando eu estou numa situação difícil, } \\
\text { eu normalmente acho uma saída. }\end{array}$ & 1 & 2 & 3 & 4 & 5 & 6 & 7 \\
\hline
\end{tabular}




\section{ANEXO V-AUTORIZAÇÕES}

DEPARTAMENTO DE PEDIATRIA DA SANTA CASA DE MISERICÓRDIA DE S PAULO

INSTITUTO DE PESQUISA

Rua Marquês de Itú nº 381 Tel.: (11) 21767000 Ramais: 8402 Santa Cecília São Paulo

Título da pesquisa: Qualidade de vida, adolescência e doença crônica.

Pesquisador responsável: $\quad$ Silvia Maria Balieiro Nigro Telefones: 99944 4065,36724240

Departamento/Unidade: Pediatria/Unidade de Adolescentes

Orientador: Orientadora: Professor. ${ }^{a}$ Dr. ${ }^{a}$ PatríciaTempski

Co-orientadora: Prof. ${ }^{a}$ Dr. ${ }^{a}$ Maria José Carvalho Sant'Anna

Finalidade da Pesquisa: () Mestrado (x) Doutorado ( ) Pós-Doutorado

() Publicação

() Trabalho de Conclusão de Curso () Indústria

Farmacêutica

() Outros - especificar

Diretor do Departamento (assinatura e carimbo)

Profa. Dra. Vera Lúcia dos Santos Alves Instituto de Pesquisa - Santa Casa SP 


\section{ANEXO VI- Termo de Compromisso}

Eu, Silvia Maria Balieiro Nigro. Pesquisador Responsável declara que estou ciente das seguintes responsabilidades:

- Iniciar a pesquisa somente após aprovação do Comitê de Ética

- Apresentar relatório parcial da pesquisa a cada seis meses (impresso disponível na página do CEP)

- Apresentar relatório de finalização da pesquisa

- No caso de suspensão da pesquisa enviar relatório com justificativa (impresso disponível na página do CEP)

- E que o atraso da entrega do relatório impedirá a apresentação de novo protocolo/documento ao CEP.

São Paulo de $20 \ldots$

Nome do pesquisador (Assinatura) 
ANEXO VII VII-

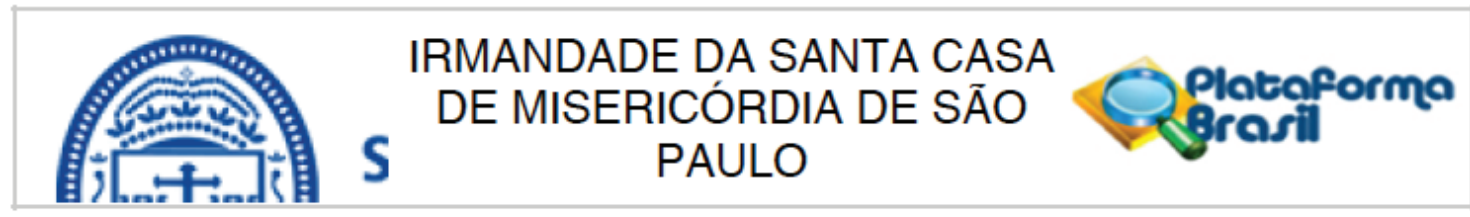

\section{PARECER CONSUBSTANCIADO DO CEP}

\section{Elaborado pela Instituição Coparticipante}

\section{DADOS DO PROJETO DE PESQUISA}

Título da Pesquisa: Qualidade de vida, adolescência e doença crônica

Pesquisador: Patricia Zen Tempski

Área Temática:

Versão: 1

CAAE: 39414314.6 .3001 .5479

Instituição Proponente: Faculdade de Medicina da Universidade de São Paulo

Patrocinador Principal: Financiamento Próprio

\section{DADOS DO PARECER}

Número do Parecer: 1.081.649

Data da Relatoria: 27/05/2015

\section{Apresentação do Projeto:}

Introdução: A transição epidemiológica da morbimortalidade atual demonstra que as doenças crônicas passaram a ser precocemente diagnosticadas e novas abordagens terapêuticas possibilitaram o aumento da sobrevida. Assim a população de adolescentes acometidos de doenças crônicas vêm crescendo significativamente.O impacto de uma doença crônica em um adolescente afeta sua qualidade de vida. A qualidade de vida e sensação de bem estar tem sido associada com o conceito de resiliência. Objetivos: O presente projeto de pesquisa tem como objetivos analisar as interações da doença crônica com as peculiaridades biopsicossociais da adolescência, o impacto na qualidade de vida, conforme as características sociodemográficas, idade e as patologias específicas dos adolescentes. Pretende-se também analisar os comportamentos de resiliência e a representação da rede de suporte envolvida com os participantes. Métodos: É um estudo transversal de amostra de conveniência com pacientes do ambulatório de especialidades pediátricas da Irmandade Santa Casa de São Paulo da Faculdade de Ciências Médicas da Santa Casa de São Paulo.

Os sujeitos da pesquisa serão adolescentes com idades entre 12-18 anos, diagnosticados com diabetes ou artrite idiopática juvenil ou anemia falciforme ou síndrome nefrótica ou cardiopatia congênita. Serão excluídos aqueles em cuidados paliativos, com patologia dermatológica, patologia

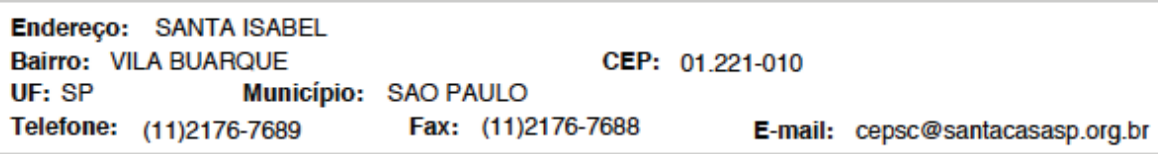




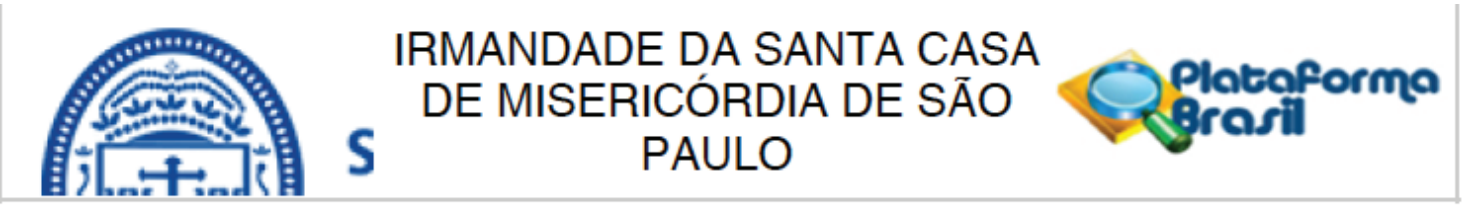

Continuaçắo do Parecer: 1.081 .649

oncológica, deficiência intelectual e os soropositivos para HIV. A coleta dos dados, será realizada por meio de grupo focal e três questionários validados: Questionário sócio demográfico, WHOQOL-BREF e RS - 14 Escala de Resiliência de Wagnild \& Young. A análise dos dados será qualiquantitativa. Hipóteses: Espera-se que adolescentes com doença crônica tenham pior qualidade de vida e desenvolvam resiliência. Assim como desejam participar do seu processo terapêutico.

\section{Objetivo da Pesquisa:}

Objetivo Primário:

Analisar as interações da doença crônica com as peculiaridades biopsicossociais da adolescência e o impacto na qualidade de vida do adolescente.

Objetivo Secundário:

Analisar as interações da doença crônica de acordo com as características sócio demográficas. Também conforme a idade e as patologias específicas.Analisar os comportamentos de resiliência identificados.Analisar a representação da rede de suporte envolvida com os participantes.

\section{Avaliação dos Riscos e Benefícios:}

Riscos:

RISCO MíNIMO

Benefícios:

Este estudo pode contribuir com um melhor conhecimento da população de adolescentes com doença crônica, fornecer suporte e para ampliar a abordagem e tratamento,ao considerá-lo como sujeito de sua vida e doença em todos os aspectos.

\section{Comentários e Considerações sobre a Pesquisa:}

Pesquisa com temática importante para prática clínica.

Considerações sobre os Termos de apresentação obrigatória:

Todos de acordo.

Recomendações:

Conclusões ou Pendências e Lista de Inadequações:

Aprovado.

Situação do Parecer:

Aprovado

Endereço: SANTA ISABEL

Bairro: VILA BUARQUE CEP: 01.221-010

UF: SP Município: SAO PAULO

Telefone: (11)2176-7689 Fax: (11)2176-7688 E-mail: cepsc@santacasasp.org.br 


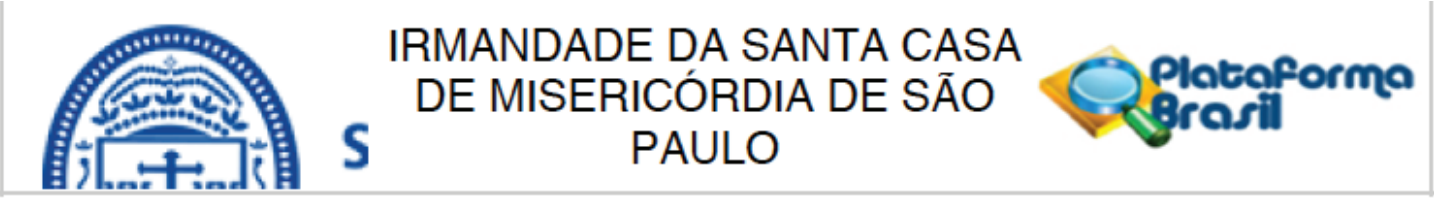

Continuaçắo do Parecer: 1.081.649

Necessita Apreciação da CONEP:

Não

Considerações Finais a critério do CEP:

SAO PAULO, 27 de Maio de 2015

Assinado por:

Nelson Keiske Ono

(Coordenador) 
ANEXO VIII

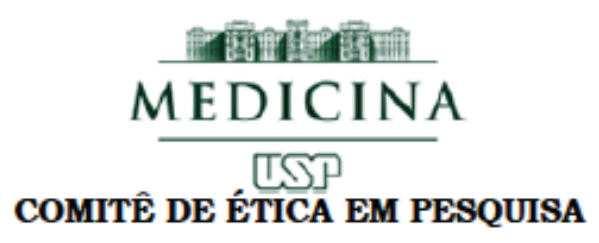

\section{APROVAÇÃo}

O Comitê de Ética em Pesquisa da Faculdade de Medicina da Universidade de São Paulo, em sessão de 10/12/2014, APROVOU o Protocolo de Pesquisa $n^{\circ}$ 397/14 intitulado: "QUALIDADE DE VIDA, ADOLESCÊNCIA E DOENÇA CRÔNICA” apresentado pelo Departamento de Clínica Médica.

Cabe ao pesquisador elaborar e apresentar ao CEPFMUSP, os relatórios parciais e final sobre a pesquisa (Resolução do Conselho Nacional de Saúde no 466/12).

Pesquisador (a) Responsável: Patricia Tempski

Pesquisador (a) Executante: Silvia Maria Balieiro Nigro

CEP-FMUSP, 10 de Dezembro de 2014.

$$
\text { Pliemenn. }
$$

Prof. Dr. Roger Chammas Coordenador Comitê de Ética em Pesquisa 


\section{Referências}

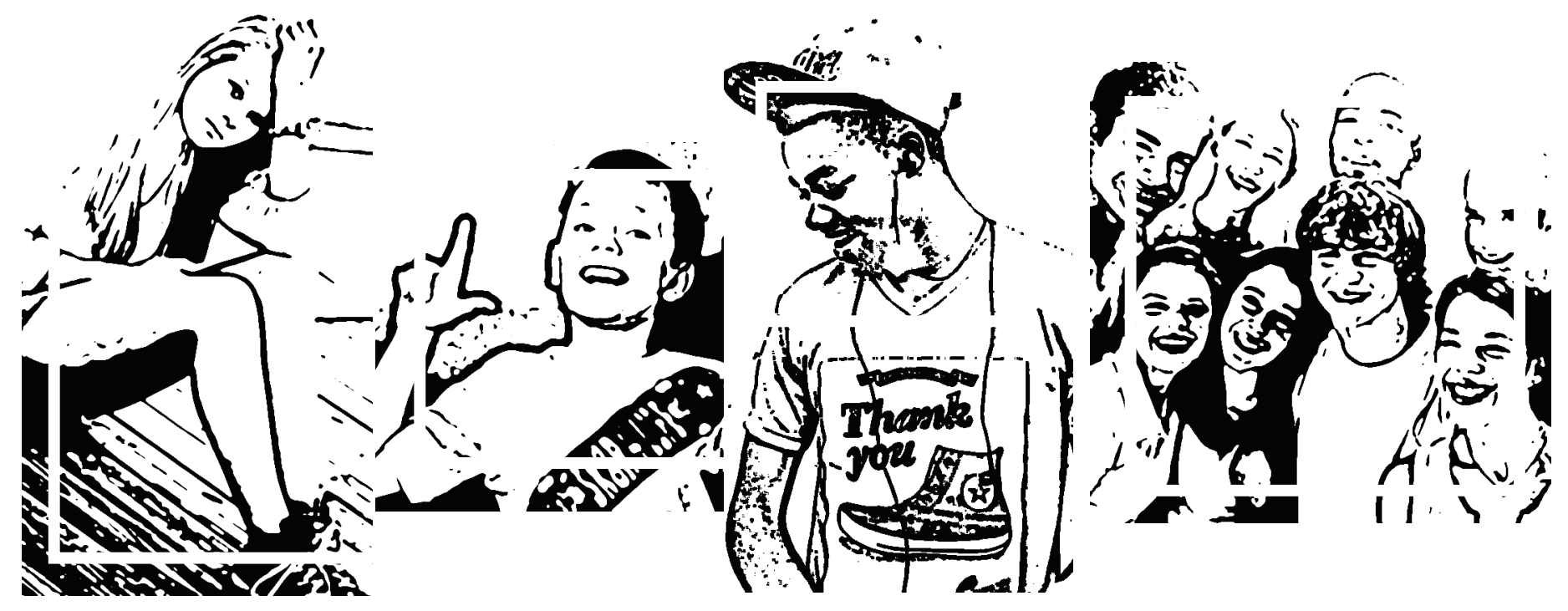




\section{REFERÊNCIAS BIBLIOGRÁFICAS}

1. Who. Global status report on noncommunicable diseases 2014. World Health. 2014.

2. PAHO WHO |:: Conceito Doenças Crônicas Não Transmissíveis (DCNT) [Internet]. Available from:

http://www.paho.org/bra/index.php?option=com_content\&view=article\&id =569:-conceito\&catid=901: bra-03-a-doencas-nao-

transmissiveis\&Itemid=539

3. Saúde. BM da SS de V em SD de A de $S$ de. Plano de ações estratégicas para o enfrentamento das doenças crônicas não transmissíveis (DCNT) no Brasil. Agravos S de V em SD de A de S de SCG de D e, P, editors. Brasília; 2011. 148 p.

4. Mokkink LB, Van Der Lee JH, Grootenhuis M a., Offringa M, Heymans HS a. Defining chronic diseases and health conditions in childhood (0-18 years of age): National consensus in the Netherlands. Eur J Pediatr. 2008;167(12):1441-7.

5. Van Der Lee J, Mokkink L, Grootenhuis M, Heymans H, Offringa M. Definitions and Measurement of A Systematic Review. JAMA. 2007;297(24):2741-51.

6. Moreira MCN, Gomes R, Sá MRC de. Doenças crônicas em crianças e adolescentes: uma revisão bibliográfica. Cien Saude Colet. 2014 ;19(7):2083-94

7. Omar HA. Adolescence and Chronic Illness : A Public Health Concern. In: Omar $\mathrm{H}$ et al, editor. Health and Human Development Series [Internet]. New York, NY, US: Nova Science Publisher,Inc.; 2010. p. 3-4.

8. Stein RE, Silver EJ. Operationalizing a conceptually based noncategorical definition: a first look at US children with chronic conditions. Arch Pediatr Adolesc Med. 1999;153(1):68-74.

9. Stein REK, Bauman LJ, Westbrook LE, Coupey SM, Ireys HT. Framework for identifying children who have chronic conditions: The case for a new defintion. J Pediatr. 1993;122(3):342-7.

10. Maslow GR, Haydon A a, Ford CA, Halpern CT. Young adult outcomes of children growing up with chronic illness: an analysis of the National Longitudinal Study of Adolescent Health. Arch Pediatr Adolesc Med. 2011;165(3):256-61.

11. Gordia A. Qualidade de vida: contexto histórico, definição, avaliação e fatores associados. Rev Bras Qual Vida. 2011;3(1):40-52.

12. Fleck MP, Louzada S, Xavier M, Chachamovich E, Vieira G, Santos L, et al. Application of the Portuguese version of the abbreviated instrument of quality life WHOQOL-bref. Rev Saude Publica. 2000;34(2):178-83. 
13. Fleck MPDA, Leal OF, Louzada S, Xavier M, Chachamovich E, Vieira G, et al. Desenvolvimento da versão em português do instrumento de avaliação de qualidade de vida da OMS (WHOQOL-100). Rev Bras Psiquiatr. 1999;21(1):19-28.

14. Whoqol Group. The World Health Organization Quality of Life assessment (WHOQOL): position paper from the World Health Organization. Soc Sci Med. 1995;41(10):1403-9.

15. Bertoletti J, Marx GC, Hattge Júnior SP, Pellanda LC. Quality of life and congenital heart disease in childhood and adolescence. Arq Bras Cardiol. 2014;102(2):192-8.

16. M. Bullinger, R. Anderson DC and NA. Developing and Evaluating CrossCultural Instruments from Minimum Requirements to Optimal Models on JSTOR. Quality of Life Research. 1993. p. 451-9.

17. Atkinson PA, Martin CR, Rankin J. Resilience revisited. J Psychiatr Ment Health Nurs. 2009;16(2):137-45.

18. Tempski $P$, Martins MA, Paro HBMS. Teaching and learning resilience: $A$ new agenda in medical education. Med Educ. 2012;46(4):345-6.

19. Rutter M. Resilience as a dynamic concept. Dev Psychopathol. 2012;24(2):335-44.

20. Ginsburg KR, Jablow MM, Ginsburg KR, American Academy of Pediatrics. Building resilience in children and teens : giving kids roots and wings. American Academy of Pediatrics; 2011. 398 p.

21. Saito,MI. Leal L. Adolescencia. Prevençao E Risco - Visão Histórica e Perspectiva atual (em) Adolescência: prevenção e risco/ Maria Ignez Saito, Luiz Eduardo Vargas da Silva e Marta Miranda Leão.. $2^{a}$ Edição. Atheneu, editor. São Paulo; 2008. 3-11 p.

22. OMS. Health Problems of Adolescents [Internet]. Geneva; 1965 [cited 2018 Feb 4]. Available from:

http://apps.who.int/iris/bitstream/10665/38425/1/WHO_TRS_308.pdf

23. World Health Organization. Young people's health - a challenge for society [Internet]. WHO Study Group on Young People. Geneva; 1986. Available from: http://whqlibdoc.who.int/trs/WHO_TRS_731.pdf

24. WHO. Regional working group on health needs of adolescents. Final Report. Unpublished document ICP/MCH/005 [Internet]. Regional Office 1980, editor. Manila, Philippines; 1980 [cited 2018 Feb 4]. Available from: https://books.google.com.br/books/about/Regional_Working_Group_on_H ealth_Needs_o.html?id=9A-oHAAACAAJ\&redir_esc=y

25. Sawyer SM, Azzopardi PS, Wickremarathne D, Patton GC. The age of adolescence. Lancet Child Adolesc Heal . 2018;0(0):1-6.

26. Câmara dos Deputados, Edições Câmara 2014. Estatuto da Criança e do 
Adolescente $12^{a}$ edição. 2014. 1-242 p.

27. BRASIL. Estatuto da criança e do adolescente. [Internet]. Ministério da educação. 2002. p. 90. Available from: www.google.com

28. CEPAL. CEPALSTAT Perfil Social PNM [Internet]. 2015 [cited 2017 Mar 19]. Available from:

http://estadisticas.cepal.org/cepalstat/Perfil_Regional_Social.html?idioma =spanish

29. Censo. IBGE Censo 2010 [Internet]. Instituto Brasileiro de Geografia e Estatística. 2010. Available from: http://censo2010.ibge.gov.br/

30. Santos T, De Matos MG, Simões MC, Do M, Machado C. Contextual factors related to chronic condition in portuguese adolescents: highlights from the HBSCMHO study. 2011;

31. Aberastury A, Knobel M. Adolescência normal. 5 ed; Artes Médicas;, editor. Porto Alegre; 1981.

32. Breinbauer C. Youth: Choices and Change. Promoting Healthy Behaviors in Adolescents. [Internet]. Scientific and Technical Publication No.584, editor. Adolescence. Washington, D.C.: PAHO; 2005. 231 p. Available from:

http://search.proquest.com.ezp.lib.unimelb.edu.au/docview/620722748?a ccountid=12372\%5Cnhttp://sfx.unimelb.hosted.exlibrisgroup.com/sfxlcl41 ?url_ver=Z39.88-

2004\&rft_val_fmt=info:ofi/fmt:kev:mtx:journal\&genre=article\&sid=ProQ:Pr oQ\%3Apsycinfo\&atitle=Youth\%3A

33. Gaete V. Desarrollo psicosocial del adolescente. Rev Chil Pediatr [Internet]. 2015;86(6):436-43.

34. Backes DS, Colomé JS, Erdmann RH. Grupo focal como técnica de coleta e análise de dados em pesquisas qualitativas The focal group as a technique for data collection and analysis in qualitative research El grupo focal como técnica para la recolección y el análisis de datos en la investigac. 2011;35(4):438-42.

35. Tempski-Fiedler P. Avaliação da qualidade de vida do estudante de medicina e da influência exercida pela formação acadêmica. Medicina ( $B$ Aires). 2008;308.

36. Soares AHR, Martins AJ, Lopes MDCB, Britto JAA, Oliveira CQ, Moreira MCN. Qualidade de vida de crianças e adolescentes: uma revisão bibliográfica. Cien Saude Colet. 2011;16(7):3197-206.

37. Barbour R, Duarte MF. Produção de dados em : Grupos focais : coleção pesquisa qualitativa. In: ARTMED, editor. Grupos focais : coleção pesquisa qualitativa. $1^{\text {a }}$. Porto Alegre: Bookman; 2009. p. 147.

38. Broadbent E, Petrie KJ, Main J, Weinman J. The Brief Illness Perception Questionnaire. J Psychosom Res. 2006;60(6):631-7. 
39. Leventhal, H., Nerenz, D.R., Steele DJ. Handbook Of Psychology And Health, Handbook Of Psychology And Health. 1st ed. Baum, A., Taylor, S.E., Singer JE, editor. Hillsdale, NJ,: Lawrence Erlbaum Associates; 1984. 219-252. p.

40. Weinman J, Petrie ' KJ, Moss-Morris R, Horne R. The Illness Perception Questionnaire: A New Method For Assessing The Cognitive Representation Of Illness. Psychol Heal . 1996;11:43-5.

41. Laurence Bardin. Análise de Conteúdo I [Internet]. $1^{\text {a }}$ Edição. Edições 70 Almedina Brasil, editor. São Paulo; 2011. 123-168 p.

42. Flick U. Introdução à pesquisa qualitativa. 2009. 405 p.

43. Gibbs G. Análise de dados qualitativos. $1^{a}$ Edição. Porto Alegre: Artmed; 2009. p. 1-195.

44. CASP UK. CASP Critical Appraisal Skills Programme Oxford UK [Internet]. 2017 [cited 2018 Feb 25]. Available from: http://www.caspuk.net/

45. Tong A, Sainsbury P, Craig J. Consolidated criterio for reporting qualitative research (COREQ): a 32- item checklist for interviews and focus group. Int J Qual Heal Care. 2007;19(6):349-57.

46. The WHOQOL Group. Whoqol-Bref: Introduction, Administration , Scoring and Generic Version of the Assessment. Program Ment Heal. 1996;(December):16.

47. Wagnild GM, Young HM. Development and psychometric evaluation of the Resilience Scale. J Nurs Meas . 1993;1(2):165-78.

48. Wagnild GM. The 14-Item Resilience Scale (RS-14). Resil Scale User's Guid US English version Resil Scale 14-Item Resil Scale. 2009;97.

49. Saude OM De. Cuidados Inovadores pas Condições Crónicas. Relatório Mund [Internet]. 2002; Available from: http://www.who.int/chp/knowledge/publications/icccportuguese.pdf

50. Manuscript A. NIH Public Access. Changes. 2012;29(6):997-1003.

51. BRASIL. Ministério da Saúde. Secretaria de Vigilância em Saúde. Departamento de Análise de Situação de Saúde. Plano de ações estratégicas para o enfrentamenteo das Doenças Crônias Não Transmissíveis (DCNT) no Brasil 2011-2022 [Internet]. PhD Proposal. Brasília: MINISTÉRIO DA SAÚDE; 2011 [cited 2017 Aug 19]. 160 p. Available from:

http://bvsms.saude.gov.br/bvs/publicacoes/plano_acoes_enfrent_dcnt_20 11.pdf

52. Instituto Brasileiro de Geografia e Estatística. Pesquisa Nacional de Saúde 2013: percepção de estado de saúde, estilo de vida e doenças crônicas [Internet]. IBGE IB de G e E, editor. Ministério da Saúde. Rio de 
Janeiro; 2014 [cited 2017 Sep 25]. 181 p. Available from: https://biblioteca.ibge.gov.br/visualizacao/livros/liv91110.pdf

53. Barros MBDA, Francisco PMSB, Zanchetta LM, César CLG. Tendências das desigualdades sociais e demográficas na prevalência de doenças crônicas no Brasil, PNAD: 2003- 2008. Cien Saude Colet. 2011;16(9):3755-68.

54. Taylor VH, Forhan M, Vigod SN, Mclntyre RS, Morrison KM. The impact of obesity on quality of life. Best Pract Res Clin Endocrinol Metab .Elsevier Ltd; 2013;27(2):139-46.

55. Marino BS, Tomlinson RS, Wernovsky G, Drotar D, Newburger JW, Mahony $L$, et al. Validation of the pediatric cardiac quality of life inventory. Pediatrics. 2010;126(3):498-508.

56. Murillo M, Bel J, Pérez J, Corripio R, Carreras G, Herrero X, et al. Healthrelated quality of life (HRQOL) and its associated factors in children with Type 1 Diabetes Mellitus (T1DM). BMC Pediatr. 2017;17(1):1-9.

57. Rivera C, Mamondi V, Lavin Fueyo J, Jouglard EF, Pogany L, Sánchez MC, Prina M, Roizen M, Esandi ME BS. Calidad de vida relacionada con la salud en niños con y sin trastornos crónicos. Estudio multicéntrico. Arch Argent Pediatr . 2015;113(5):404-10.

58. Shorer M, David R, Schoenberg-Taz M, Levavi-Lavi I, Phillip M, Meyerovitch J. Role of parenting style in achieving metabolic control in adolescents with type 1 diabetes. Diabetes Care. 2011;34(8):1735-7.

59. Moorthy LN, Roy E, Kurra V, Peterson MGE, Hassett AL, Lehman TJA, et al. Health related quality of life measure in systemic pediatric rheumatic diseases and its translation to different languages : an international collaboration. 2014;1-6.

60. Rüth E-M, Landolt M a, Neuhaus TJ, Kemper MJ. Health-related quality of life and psychosocial adjustment in steroid-sensitive nephrotic syndrome. J Pediatr. 2004;145(6):778-83.

61. Marciano RC, Soares CMB, Diniz JSS, Lima EM, Silva JMP, Canhestro $\mathrm{MR}$, et al. Transtornos mentais e qualidade de vida em crianças e adolescentes com doença renal crônica e em seus cuidadores. J Bras Nefrol [Internet]. 2010;32(3):316-22.

62. Alvarenga TMM, Caldeira AP. Quality of life in pediatric patients with atopic dermatitis. J Pediatr (Rio J). 2009;85(5):415-20.

63. Alriksson-Schmidt Al, Wallander J, Biasini F. Quality of Life and Resilience in Adolescents with a Mobility Disability. J Pediatr Psychol . 2007;32(3):370-9.

64. Com EAR, Saúde AE, Família DA. Doença crônica da criança: necessidades familiares e a relação com a estratégia saúde da família. 2013;34(3):72-8. 
65. Castro EK De. Implicações da Doença Orgânica Crônica na Infância para as Relações Familiares : Algumas Questões Teóricas. 2002;15(3):625_ 35.

66. Tai E, Buchanan N, Townsend J, Fairley T, Moore A, Richardson LC. Health status of adolescent and young adult cancer survivors. Cancer. 2012;118(19):4884-91.

67. Zeller MH, Inge TH, Modi AC, Jenkins TM, Michalsky MP, Helmrath M, et al. Severe Obesity and Comorbid Condition Impact on the Weight-Related Quality of Life of the Adolescent Patient. J Pediatr. Elsevier Inc; 2014;166(3):651-659.e4.

68. A. Christin, C. Akre AB and JCS. Parent-adolescent relationship in youths with a chronic condition. Child Care Heal Dev .2016 [cited 2017 Aug 5];42(1)(365-2214):36-41.

69. Heath G, Farre A, Shaw K. Parenting a child with chronic illness as they transition into adulthood: A systematic review and thematic synthesis of parents' experiences. Patient Education and Counseling. 2017.

70. Nielsen KM, Mandleco B, Roper SO, Cox A, Dyches T, Marshall ES. Parental Perceptions of Sibling Relationships in Families Rearing a Child With a Chronic Condition. J Pediatr Nurs . Elsevier Inc.; 2012;27(1):3443. A

71. Oris L, Seiffge-Krenke I, Moons P, Goubert L, Rassart J, Goossens E, et al. Parental and peer support in adolescents with a chronic condition: a typological approach and developmental implications. J Behav Med. 2016;39(1).

72. Knafl K a., Deatrick J a., Knafl GJ, Gallo AM, Grey M, Dixon J. Patterns of family management of childhood chronic conditions and their relationship to child and family functioning. J Pediatr Nurs [Internet]. Elsevier B.V.; 2013;28(6):523-35.

73. Teresa Cristina da Cruz Fatela dos Santos. Qualidade De Vida, Percepção De Saúde, Resiliência, Auto- Regulação E Suporte Social Nos Adolescentes Portugueses Com Doença Crónica [QUALITY. Faculdade de Medicina/Universidade de Lisboa; 2016.

74. Sawyer SM, Drew S, Yeo MS, Britto MT. Adolescents with a chronic condition: challenges living, challenges treating. Lancet Elsevier Ltd; 2007;369(9571):1481-9.

75. WHO. Growing up unequal: gender and socioeconomic differences in young people's health and well-being. 2016;(7):213-36.

76. PENSE. Pesquisa Nacional da Saúde do Escolar (PeNSE). Ciência \& Saúde Coletiva. 2012. 3006-3006 p.

77. Eaton DK, Kann L, Kinchen S, Shanklin S, Flint KH, Hawkins J, et al. Youth risk behavior surveillance - United States, 2011. MMWR Surveill 
Summ [Internet]. 2012;61(4):1-162. Available from: http://www.ncbi.nlm.nih.gov/pubmed/23904581

78. Ministério, da Saúde, Centro Brasileiro de Análise e Planejamento. Brasília : Ministério da Saúde 2009. Pesquisa Nacional de Demografia e Saúde da Criança e da Mulher: PNDS 2006: Dimensões do Processo Reprodutivo e da Saúde da Criança. São Paulo: CEBRAP. 2009. p. 135149. $p$.

79. Secretaria da Educação do Estado de São Paulo. Resolução SE 53 [Internet]. 2014 [cited 2017 Oct 20]. Available from: http://siau.edunet.sp.gov.br/ItemLise/arquivos/53_14.HTM

80. Tempski P, Santos IS, Mayer FB, Enns SC, Perotta B, Paro HBMS, et al. Relationship among Medical Student Resilience, Educational Environment and Quality of Life. 2015;1-13.

81. Werner EE. High-Risk Children In Young Adulthood: A Longitudinal Study from Birth to 32 Years. Amer J Orthopsychiat . 1989 [cited 2017 Oct 20];59(1):72-81.

82. Martins E, Szymanski H. Artigos A Abordagem Ecológica De Urie Bronfenbrenner Em Estudos Com Famílias The Ecological Approach Of Urie Bronfenbrenner In Studies With Families. Estud E Pesqui EM Psicol [Internet]. 2004 [cited 2017 Nov 5];1:63-77.

83. Bronfenbrenner U. Ecological Models of Human Development. In: Elsevier Sciences L, editor. International Encyclopedia of Education. $2^{a}$. Oxford; 1994. p. 37-43.

84. Paula Silva Fernandes. Relação entre Competências Sociais e Qualidade de Vida em Adolescentes. Universidade Lusófona de Humanidades e Tecnologias; 2016.

85. Edinete Maria Rosa and Jonathan Tudge. Urie Bronfenbrenner's Theory of Human Development: Its Evolution From Ecology to Bioecology. J Fam Theory Rev. 2013;5:243-58.

86. Crump C, Rivera D, London Phd R, Landau Msn M, Phd BE, Rodriguez Drph E. Chronic health conditions and school performance among children and youth. Ann Epidemiol. 2013;23:179-84.

87. Bethell CD, Newacheck P, Hawes E, Halfon N. Adverse childhood experiences: Assessing the impact on health and school engagement and the mitigating role of resilience. Health Aff. 2014;33(12):2106-15.

88. Champaloux SW, Young DR. Childhood Chronic Health Conditions and Educational Attainment: A Social Ecological Approach. J Adolesc Heal . 2015;56:98-105.

89. Suris J-C, Michaud P, Viner R. The adolescent with a chronic condition. Part I: developmental issues. Arch Dis Child. 2004;89(10):938-42. 
90. Burns JJ, Sadof M, Kamat D. The adolescent with a chronic illness. Pediatr Ann [. 2006;35(3):206-10, 214-6.

91. Michaud P, Suris J-C, Viner R. The adolescent with a chronic condition. Part II: healthcare provision. Arch Dis Child. 2004;89(10):943-9.

92. Calligaris C. A adolescência. $1^{\text {a }}$. Arthur Nestrovski, editor. São Paulo: Publifolha; 2000. 1-88 p.

93. Sampaio ITA. Inventário de Estilos Parentais ( IEP ): um novo instrumento para avaliar as relações entre pais e filhos. Psico-USF. 2007 ;12(1):125-6.

94. Inez P, Gomide C, Patricia D, Pinheiro N, Sabbag GM. Correlação entre práticas educativas, depressão, estresse e habilidades sociais. PsicoUSF. $2005 ; 10(2): 169-78$.

95. Santos T, Simões MC, Tomé G. Estilos Parentais e desenvolvimento positivo em crianças e adolescentes com doença crónica Parenting styles and positive development in children and adolescents with chronic condition. Rev Psicol da Criança e do Adolesc. 2013;4(2):185-203.

96. Wolman C, Resnick MD, Harris LJ, Blijivi RW. Emotional Well-being among adolescents with and witout cjronic conditions. J Adolesc Heal . 1994;15:199-204.

97. Sentenac M, Gavin A, Gabhainn SN, Molcho M, Due P, Ravens-Sieberer $U$, et al. Peer victimization and subjective health among students reporting disability or chronic illness in 11 Western countries. Eur J Public Health.;23(3):421-6.

98. Pinquart M. Body image of children and adolescents with chronic illness: A meta-analytic comparison with healthy peers. Body Image 2013 ;10:141-8.

99. Latner,JD, Stunkard A. Getting Worse: The Stigmatization of Obese Children. Obes Res . 2003;11(3):452-6.

100. Puhl RM. Weight discrimination and bullying. Best Pract Res Clin Endocrinol Metab . 2013;27:117-27.

101. Puhl RM, Latner JD. Stigma, Obesity, and the Health of the Nation's Children. Psychol Bull. 2007;133(4):557-80.

102. Kaminsky Phd LA, Phd DD, Kaminsky LA. The Association between Body Mass Index and Physical Activity, and Body Image, Self Esteem and Social Support in Adolescents with Type 1 Diabetes. Can J Diabetes . $2014[; 38: 244-9$.

103. Phillips J, De Freitas J, Mott C, Gruber J, Knobe J. True happiness: The role of morality in the folk concept of happiness. J Exp Psychol Gen .2017;146(2):165-81. 
104. Seligman MEP. Florescer - Uma Nova E Visionária Interpretação Da Felicidade E Do Bem-esta. Lopes CP, editor. Rio de Janeiro: Objetiva; 2012. $368 \mathrm{p}$.

105. FrankI VE, Shlupp WO, Aveline CC. Em busca de sentido : um psicólogo no campo de concentração. Petrópolis: Vozes; 1991. 136 p.

106. Helliwell J, Layard R, Sachs J. World Happiness Report 2017 [Internet]. Jan-Emmanuel De Neve HH and SW, editor. New York: Sustainable Development Solutions Network.; 2017 [cited 2018 Feb 4]. 188 p.

Available from: http://worldhappiness.report/wpcontent/uploads/sites/2/2017/03/HR17.pdf

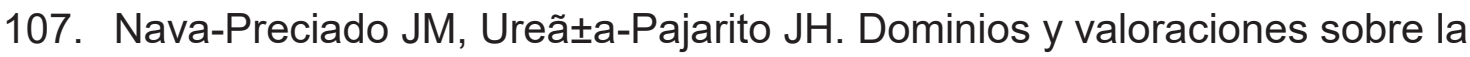
felicidad en adolescentes de Guadalajara-México TT - Domains and assessments of happiness among adolescents from Guadalajara-Mexico. TT - Domínios e valorações sobre a felicidade em adolescentes de Guadalajara, no México. Rev Latinoam Ciencias Soc Niñez y Juv . 2017;15(1):443-54.

108. Prensky M. On the Horizon. Horiz Libr Hi Tech News . 2001 ;9(3):12-3.

109. Suris J-C, Akré C, Berchtold A, Bélanger RE, Michaud P-A. Chronically Connected? Internet Use Among Adolescents With Chronic Conditions. J Adolesc Heal . 2010;46:200-2. 7d48

110. Tsitsika AK, Tzavela EC, Janikian M, Ólafsson K, lordache A, Schoenmakers TM, et al. Online social networking in adolescence: Patterns of use in six European countries and links with psychosocial functioning. J Adolesc Heal. 2014;55(1):141-7.

111. Waldinger,RJ;Shulz,M;Vaillant G. Harvard Second Generation Study [Internet]. [cited 2017 Oct 22]. Available from:

http://www.adultdevelopmentstudy.org/

112. Shah SB; Barsky AJ; Vaillant G; Waldinger RJ. Childhood environment as a predictor of perceived health status in late life. Heal Psychol Res 2014;2(1569):96-100.

113. Carter B, Qualter P, Dix J. Social relationships, loneliness and adolescence: The potential for disruption by chronic illness. J Child Heal Care. $2015 ; 19(4): 421-2$.

114. Helgeson VS, Holmbeck GN. An introduction to the special issue on peer relations in youth with chronic illness. Journal of Pediatric Psychology. 2015. p. 267-71.

115. Helgeson, V. S., \& Palladino DK. Implications of Psychosocial Factors for Diabetes Outcomes among Children with Type 1 Diabetes: A Review. Soc Personal Psychol Compass. 2012;6:228-242.

116. Helgeson VS, Mascatelli K, Reynolds KA, Becker D, Escobar O, Siminerio L. Friendship and Romantic Relationships Among Emerging 
Adults With and Without Type 1 Diabetes. J Pediatr Psychol. 2015 3(40):359-72.

117. Griggs S, Walker RK. The Role of Hope for Adolescents with a Chronic IIIness: An Integrative Review. J Pediatr Nurs. Elsevier Inc.; 2016;31(4):404-21.

118. Rollnick S, Miller WR, Butler CC. Entrevista motivacional no cuidado da saúde : ajudando os pacientes a mudar o comportamento. Porto Alegra: Grupo A - Artmed; 2009

119. Mercer ,S W and Reynolds WJ. Thinking about quality. Br J Gen Pract. 2002;(Quality Supplement).

120. Review A, Stepien KA, Baernstein A. Educating for Empathy. J Gen Intern Med 2006 . 2006;21((5)):524-30. 1-0524.pdf

121. Hanghøj S, Boisen KA. Self-reported barriers to medication adherence among chronically ill adolescents: A systematic review. Journal of Adolescent Health. 2014 . p. 121-38.

122. de Benedictis D, Bush A. Asthma in adolescence: Is there any news? Pediatric Pulmonology. 2017. p. 129-38. 